으

ARGONNE NATIONAL LABORATORY

P. O. Box 299

Lemont, Illino is

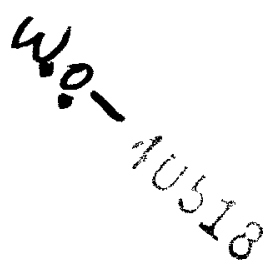

\title{
ABSORPTION SPECTRA OF URANYL COMPOUNDS IN SOLUTION
}

by

Eugene Rabinowitch

\section{INFORMATION DIVISION}

December 1953

This paper will be published as part of The Chemistry of Uranium, Part II, National Nuclear Energy Series Division VIII. It is is sued at this time to permit review and comment prior to publication and to make the information available to other Atomic Energy Commission laboratories promptly.

Operated by The University of Chicago

under

Contract W -31-10.9-eng -38 


\section{DISCLAIMER}

This report was prepared as an account of work sponsored by an agency of the United States Government. Neither the United States Government nor any agency Thereof, nor any of their employees, makes any warranty, express or implied, or assumes any legal liability or responsibility for the accuracy, completeness, or usefulness of any information, apparatus, product, or process disclosed, or represents that its use would not infringe privately owned rights. Reference herein to any specific commercial product, process, or service by trade name, trademark, manufacturer, or otherwise does not necessarily constitute or imply its endorsement, recommendation, or favoring by the United States Government or any agency thereof. The views and opinions of authors expressed herein do not necessarily state or reflect those of the United States Government or any agency thereof. 


\section{DISCLAIMER}

Portions of this document may be illegible in electronic image products. Images are produced from the best available original document. 


$$
\cdot 1
$$

\section{TABLE OF CONTENTS}

$\underline{\text { Page }}$

1. Absorption Spectra of the Free (Hydrated) Uranyl Ion and of 2 the Products of Its Hydrolysis .................

2. Absorption Spectra of Uranyl Ions Complexed with Acid Anions . 15 2.1 Effect of Inorganic Anions on Uranyl Spectrum in Solution . . 15 2.2 Complexing with Organic Ions. .............. 23

3. Absorption Spectra of Uranyl Compounds in Organic Solvents. . . 45

4. Raman Spectrum and Infrared Spectrum of Uranyl Salt Solutions. . 66 


\section{ABSORPTION SPECTRA OF THE FREE (HYDRATED) URANYL ION AND OF THE PRODUCTS OF ITS HYDROLYSIS}

Free $\mathrm{U}^{+6}$ ions do not occur in solution; if a compound derived from this ion, such as $\mathrm{UF}_{6}$, comes in contact with water, it is immediately hydrolyzed, i.e., associated with the anions of water, even at the lowest accessible $\mathrm{pH}$ values. The first step in this hydrolysis can be written as:

$$
\begin{aligned}
& \mathrm{U}^{+6}+4 \mathrm{OH}^{-} \longrightarrow \mathrm{UO}_{2}^{++}+2 \mathrm{H}_{2} \mathrm{O}, \text { or } \\
& \mathrm{U}^{+6}+2 \mathrm{O}^{=} \longrightarrow \mathrm{UO}_{2}^{++}
\end{aligned}
$$

and leads to the divalent uranyl ion, which is stable over a considerable pH range. Further hydrolysis occurs in non-complexed solutions at about pH 2, and ends in precipitation; certain anions, such as the citrate ion, can prevent their precipitation up to $\mathrm{pH} 10$ by forming soluble complexes with uranyl ions (see Section 2).

Most of the solid U(VI) compounds are salts derived from the divalent uranyl ion. Their dissolution in water produces solutions whose spectrum is the result of superposition of the spectrum of free (hydrated) uranyl ion $\left\{\mathrm{UO}_{2}^{++}\right\}$aq (perhaps $\mathrm{UO}_{2}^{++} \cdot 6 \mathrm{H}_{2} \mathrm{O}$ ) and of the spectra of complexes of this ion with the anions present in solution. In addition to simple complexes of the type $\left\{\mathrm{UO}_{2}^{++} \mathrm{X}^{-n}\right\}+(2-n)$, complexes containing two or more uranyl ions bridged by divalentanions may occur. The stepwise hydrolysis of uranyl ions, in particular, probably involves the formation of two polyuranyl complexes, $\left\{\left(\mathrm{UO}_{2}\right)_{2} \mathrm{O}\right\}^{++}\left(=\mathrm{U}_{2} \mathrm{O}_{5}^{++}\right)$and $\left\{\left(\mathrm{UO}_{2}\right)_{3} \mathrm{O}_{2}\right\}^{++}\left(=\mathrm{U}_{3} \mathrm{O}_{8}^{++}\right)$. A precise and systematic study of the extinction curves of solutions of varying compositions, concentration, acidity and ionic strength is needed for reliable interpretation of the absorption spectrum of a given uranyl salt.

To obtain the spectrum of the free (hydrated) uranyl ion, one has to use salt solutions that contain no complexes with the anions of water and of. acids. For this purpose strongly acid perchlorate solutions are best, because $\mathrm{ClO}_{4}^{-}$is the anion with the least tendency for complexing; Sutton (1947) found that adding sodium perchlorate to a $0.04 \mathrm{M} \mathrm{UO}_{2}\left(\mathrm{ClO}_{4}\right)_{2}$ solution caused no change in spectrum up to a total concentration of $3 \mathrm{M} \mathrm{ClO}_{4}^{-}$. The presence of excess perchloric acid is the best means to prevent association of $\mathrm{UO}_{2}^{++}$cations with the anions of water without introducing complexing with the anions of the acid.

Absorption curves of uranyl perchlorate solutions were first reproduced by von Kiss and co-workers (1942a,b); but they do not agree with the curves obtained in the more recent and careful measurements by Sutton and Ahrland. 
The change in the absorption curve of a uranyl perchlorate solution in perchloric acid with decreasing concentration of the latter is shown in Figure 2.1 (after Sutton). This figure indicates a strong increase in absorption throughout the spectrum at $\mathrm{pH}$ values above 2.5 (cf. Figure 2.2, which shows $\Sigma$ at $416 \mathrm{~m} \mu$ as function of $\mathrm{pH}$ ). Sutton attributed this change to a stepwise hydrolysis, beginning with the formation of the polyuranyl complexes, $\left(\mathrm{UO}_{2}\right)_{2} \mathrm{O}^{++}$and $\left(\mathrm{UO}_{2}\right)_{3} \mathrm{O}_{2}^{++}$. This type of complexing can be represented in several ways: as a substitution reaction of $\mathrm{UO}_{2}^{++}$ions with $\mathrm{H}_{2} \mathrm{O}$ molecules or $\mathrm{OH}^{-}$ions, or as an association with $\mathrm{O}^{--}$ions. (The concentration of the latter is extremely low so that hydrolysis is unlikely to proceed through their intermediary; but, formally, polyuranyl complexes of this type are most easily understood as products of association of $\mathrm{O}^{--}$ anions with $\mathrm{UO}_{2}^{++}$cations.) The three alternative interpretations are represented by the following pairs of equations:

Exchange reactions with water molecules:

$$
\begin{aligned}
& 2 \mathrm{UO}_{2}^{++}+\mathrm{H}_{2} \mathrm{O} \stackrel{\mathrm{K}_{1}}{\rightleftharpoons}\left\{\left(\mathrm{UO}_{2}\right)_{2} \mathrm{O}^{++}\left(=\mathrm{U}_{2} \mathrm{O}_{5}^{++}\right)+2 \mathrm{H}^{+}\right. \\
& \left\{\left(\mathrm{UO}_{2}\right)_{2} \mathrm{O}\right\}^{++}+\mathrm{UO}_{2}^{++}+\mathrm{H}_{2} \mathrm{O} \stackrel{\mathrm{K}_{2}}{\rightleftharpoons}\left\{\left(\mathrm{UO}_{2}\right)_{3} \mathrm{O}_{2}\right\}^{++}\left(=\left\{\mathrm{U}_{3} \mathrm{O}_{8}\right\}^{++}\right)+2 \mathrm{H}^{+}
\end{aligned}
$$

Exchange reactions with hydroxyl ions:

$$
\begin{aligned}
& 2 \mathrm{UO}_{2}^{++}+2 \mathrm{OH}^{-} \rightleftharpoons\left\{\left(\mathrm{UO}_{2}\right)_{2} \mathrm{O}\right\}^{++}+\mathrm{H}_{2} \mathrm{O} \\
& \left\{\left(\mathrm{UO}_{2}\right)_{2} \mathrm{O}\right\}^{++}+\mathrm{UO}_{2}^{++}+2 \mathrm{OH}^{-} \rightleftharpoons\left\{\left(\mathrm{UO}_{2}\right)_{3} \mathrm{O}_{2}\right\}^{++}+\mathrm{H}_{2} \mathrm{O}
\end{aligned}
$$

Associations with $\mathrm{O}^{--}$ions:

$$
\begin{aligned}
& 2 \mathrm{UO}_{2}^{++}+\mathrm{O}^{--} \rightleftharpoons\left\{\left(\mathrm{UO}_{2}\right)_{2} \mathrm{O}\right\}^{++} \\
& \left\{\left(\mathrm{UO}_{2}\right)_{2} \mathrm{O}\right\}^{++}+\mathrm{UO}_{2}^{++}+\mathrm{O}^{--} \rightleftharpoons\left\{\left(\mathrm{UO}_{2}\right)_{2} \mathrm{O}_{2}\right\}^{++}
\end{aligned}
$$

Sutton calculated the absorption curves (Figure. 2.3) of the three postulated ionic species using the following equilibrium constants derived from $\mathrm{pH}$ measurements:

$$
\begin{aligned}
& \mathrm{K}_{1}=1.24 \times 10^{-6} \\
& \mathrm{~K}_{2}=2.5 \times 10^{-7}
\end{aligned}
$$

(These constants are, of course, strongly dependent on ionic strength.)

The choice of equilibria (1) and (2), in preference to the simpler hydrolytic equilibria involving one uranyl ion only:

$$
\begin{aligned}
& \mathrm{UO}_{2}^{++}+\mathrm{H}_{2} \mathrm{O} \rightleftharpoons \mathrm{UO}_{2} \mathrm{OH}^{+}+\mathrm{H}^{+}\left(\text {or } \mathrm{UO}_{2}^{++}+\mathrm{OH}^{-} \rightleftharpoons \mathrm{UO}_{2} \mathrm{OH}^{+}\right) \\
& \mathrm{UO}_{2} \mathrm{OH}^{+}+\mathrm{H}_{2} \mathrm{O} \rightleftharpoons \mathrm{UO}_{2}(\mathrm{OH})_{2}\left(=\mathrm{UO}_{3} \cdot \mathrm{H}_{2} \mathrm{O}\right)+\mathrm{H}^{+}\left(\text {or } \mathrm{UO}_{2} \mathrm{OH}^{+}+\mathrm{OH}^{-}\right. \\
& \left.\rightleftharpoons \mathrm{UO}_{2}(\mathrm{OH})_{2}\right)
\end{aligned}
$$

was first proposed by MacInnes and Longsworth (1942), who found that Equation (1) with $K_{1}=1.35 \times 10^{-6}$ accounted well for the results of $\mathrm{pH}$ meas urements on stoichiometric $\mathrm{UO}_{2} \mathrm{Cl}_{2}$ [or $\mathrm{UO}_{2}\left(\mathrm{NO}_{3}\right)_{2}$ ] solutions, as well as for those of $\mathrm{pH}$ and conductance measurements on $\mathrm{UO}_{3}$ solutions in hydrochloric 


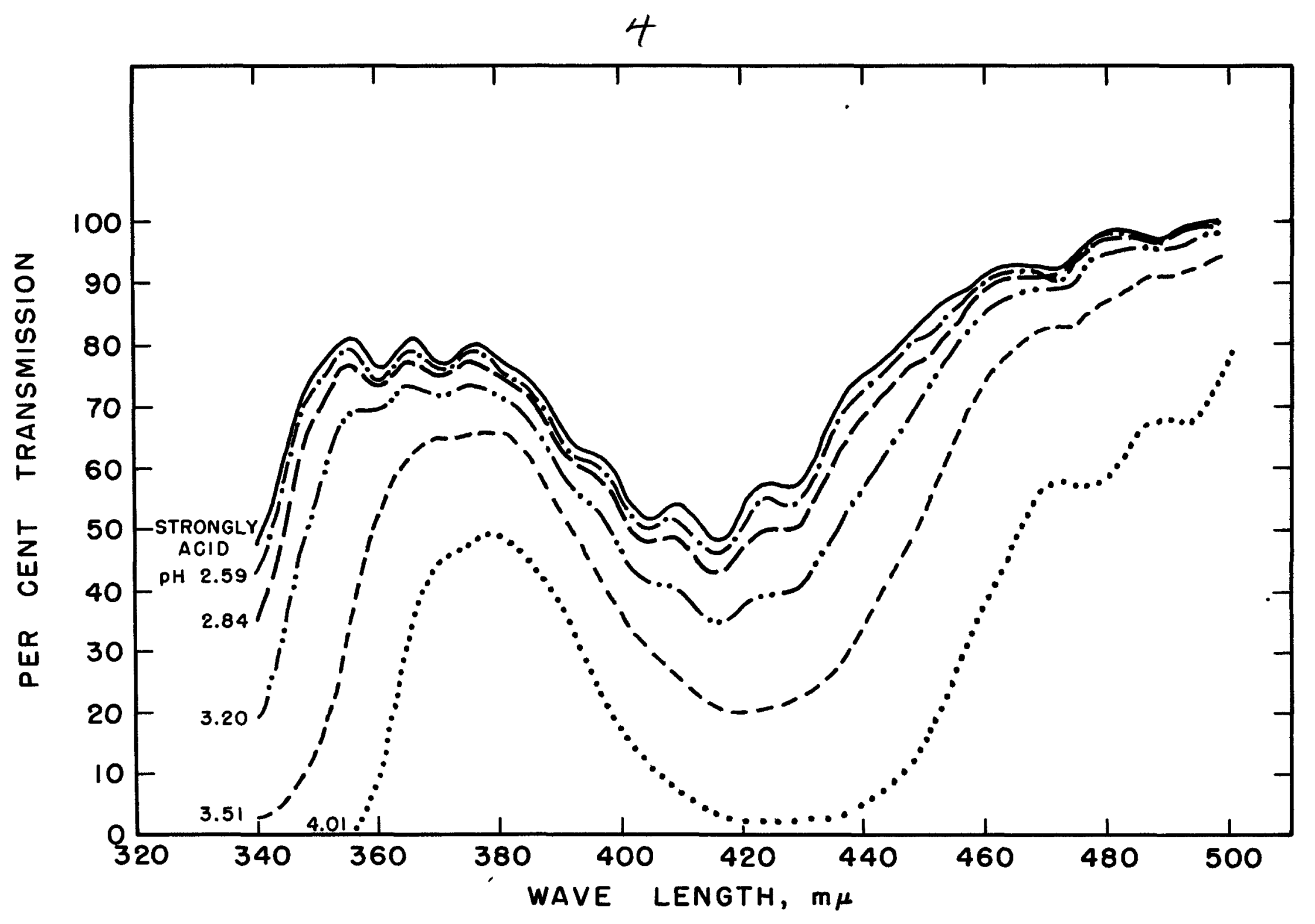

FIG. 2.I - VARIATION OF ABSORPTION OF URANYL PERCHLORATE WITH PH (after Sutton, 1947). 


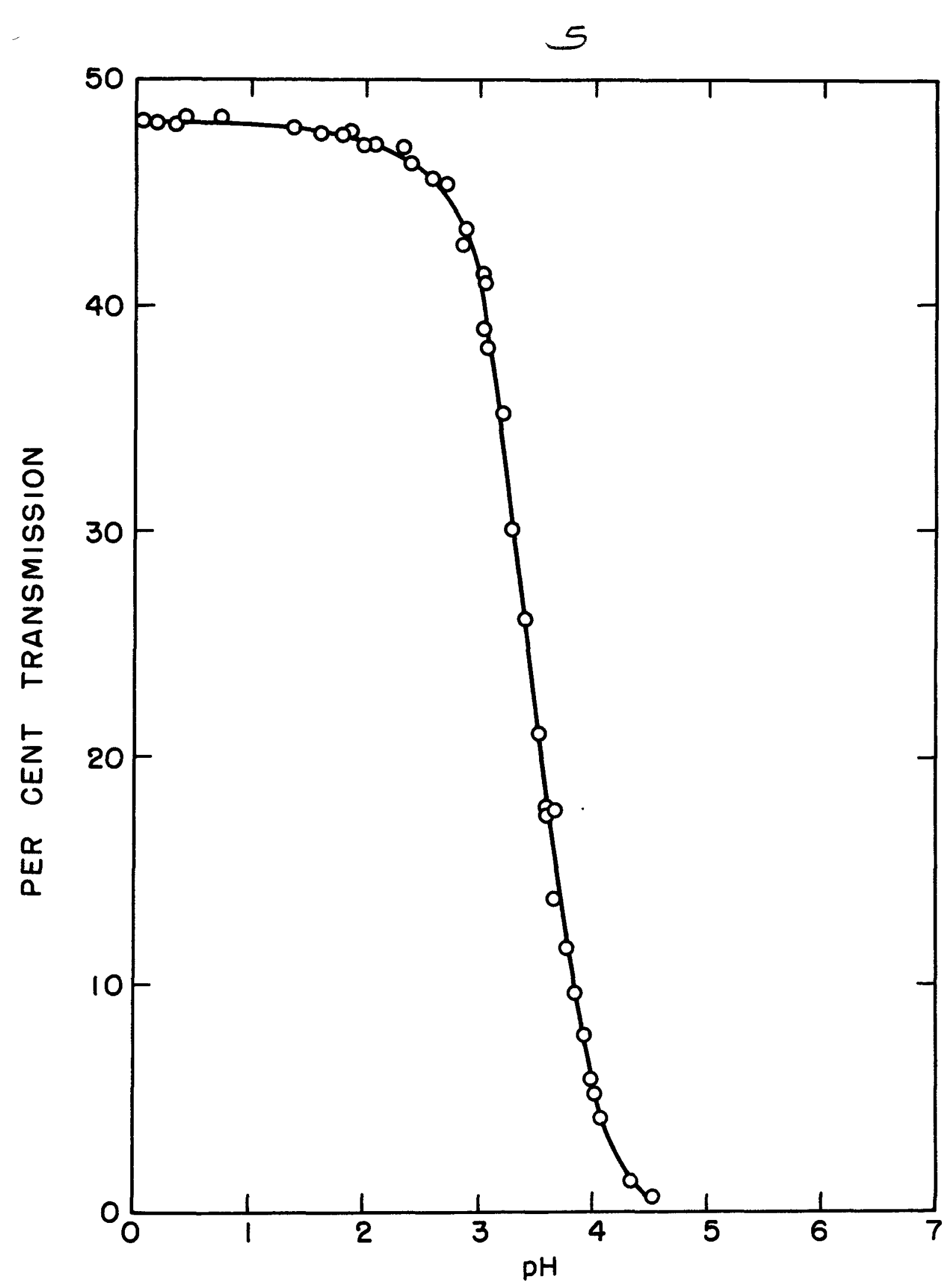

FIG. 2.2-PER GENT TRANSMISSION vS. PH FOR URANYL PERCHLORATE SOLUTIONS AT $\lambda=416$. IONIC STRENGTH $=0.17226$. 


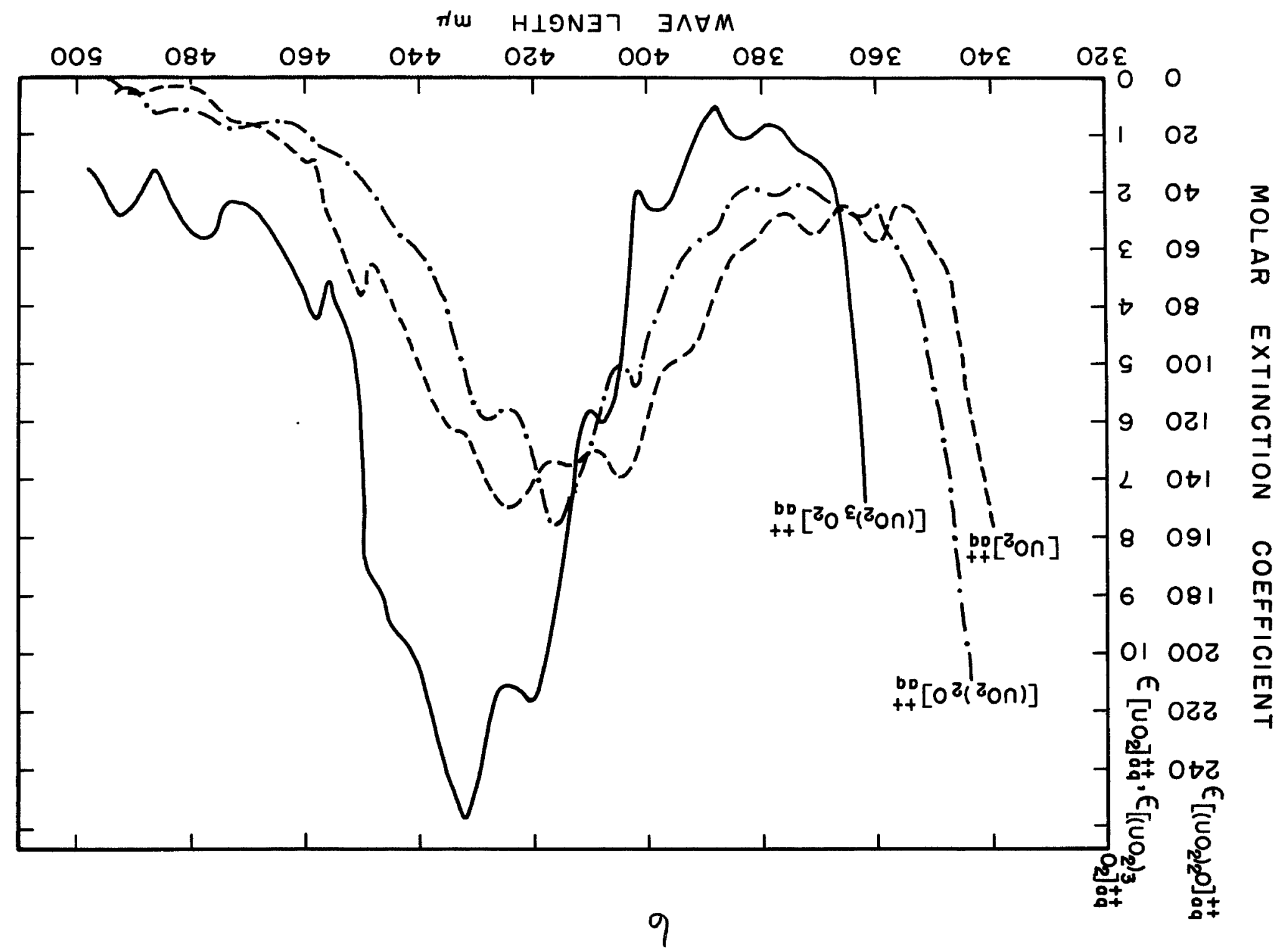


7

acid, while Equation (9) could be used to represent the second but not the first type of data. The second hydrolysis step, too, they thought more likely to be of type (2) than of type (3), among other reasons, because the second alternative would have required $\mathrm{UO}_{3}$ to be soluble in water, which is not the case. Sutton (1947) pointed out that a further argument in favor of reaction sequence (1) (2) can be derived from the fact that $\mathrm{U}_{3} \mathrm{O}_{8}$, rather than $\mathrm{UO}_{3}$, is deposited on the cathode in the electrolysis of uranyl solutions.

Robins on and Lim (1951) found that the vapor pressure lowering of uranyl perchlorate solutions increases when excess $\mathrm{UO}_{3}$ is added. This agrees with the assumption that these solutions contain $\mathrm{U}_{2} \mathrm{O}_{5}^{++}$rather than $\mathrm{UO}_{2} \mathrm{OH}^{+}$ions.

The extinction curve of $\left\{\mathrm{UO}_{2}^{++}\right\}$aq was derived by Sutton from the empirical absorption curve of uranyl perchlorate at $\mathrm{pH}<2.5$, a region where the concentrations of the complex ions are negligible; that of $\left\{\left(\mathrm{UO}_{2}\right)_{2} \mathrm{O}\right\}$ aq was computed from the absorption spectrum at $\mathrm{pH}$ 2.5-3.0, where the third ionic species can be neglected. The extinction curve of this third species, $\left\{\left(\mathrm{UO}_{2}\right)_{3} \mathrm{O}_{2}\right\}_{\text {aq }}^{++}$, was estimated rather roughly from the empirical absorption curves at $\mathrm{pH}^{>}>3$.

According to Figure 2.2, the complex ion $\left\{\left(\mathrm{UO}_{2}\right)_{2} \mathrm{O}\right\}_{\text {aq }}^{++}$has a somewhat stronger absorption in the visible region than does the simple ion $\left\{\mathrm{UO}_{2}\right\}_{\mathrm{aq}}^{++}$; its absorption is relatively weaker in the region $360-410 \mathrm{~m} \mu$, and again becomes stronger below $360 \mathrm{~m} \mu$. The ion $\left\{\left(\mathrm{UO}_{2}\right)_{3} \mathrm{O}_{2}\right\}_{\text {aq }}^{++}$is much more intensely colored than the other two; its absorption peak at $435 \mathrm{~m} \mu$ reaches an estimated height of $\epsilon_{\max }=250$, whereas $\epsilon_{\max }=8$ for the two other species (at $418 \mathrm{~m} \mu$ for $\left\{\mathrm{UO}_{2}\right\}_{\mathrm{aq}}^{++}$, and at $425 \mathrm{~m} \mu$ for $\left\{\left(\mathrm{UO}_{2}\right)_{2} \mathrm{O}_{\mathrm{aq}}^{++}\right.$, respectively).

The wave lengths of the peaks of the absorption bands of the three ionic species postulated by Sutton, taken from the curves in Figure 2.3, are listed in Table 2.1 .

Comparison of the wave length table given by Pringsheim (1937) for a $0.05 \mathrm{M}$ uranyl sulfate solution (without added acid) with Table 2.1 indicates that the spectrum obtained by Pringsheim must have been that of a partly hydrolyzed solution containing the ions $\mathrm{UO}_{2}^{++}$and $\mathrm{U}_{2} \mathrm{O}_{5}^{++}$. The same applies to McBrady and Livingston's (1946) absorption curve of a $0.01 \mathrm{M}$ solution of uranyl sulfate. Sutton gave Table 2.2 for the absorption coefficients of a stoichiometric uranyl perchlorate solution. The values in this table are averages of measurements in the concentration range 0.01 to $0.2 \mathrm{M}$, the $\mathrm{pH}$ being kept below 2.0 to avoid hydrolysis. Beer's law was found to be valid, under these conditions, up to at least $3 \mathrm{M}$. 
Table 2.1

ABSORPTION BANDS OF URANYL IONS AND THEIR COMPLEXES WITH WATER IONS AT ROOM TEMPERATURE (After Sutton)

\begin{tabular}{|c|c|c|c|c|c|c|}
\hline \multirow{2}{*}{$\begin{array}{c}\text { Band } \\
\text { No. }\end{array}$} & $\multicolumn{2}{|c|}{\mathrm{UO}_{2}}_{\mathrm{aq}}^{++} \quad(\mathrm{pH}<2.0)$ & \multicolumn{2}{|c|}{$\left(\mathrm{UO}_{2}\right)_{2} \mathrm{O}$} $\mathrm{aq}$ & $\multicolumn{2}{|c|}{\left(\mathrm{UO}_{2}\right)_{3} \mathrm{O}_{2}}^{+++} \quad(\mathrm{pH}>3)$ \\
\hline & $\stackrel{\lambda}{\mathrm{m} \mu}$ & $\mathrm{cm}^{\nu}-1$ & $\stackrel{\lambda}{\mathrm{m} \mu}$ & $\mathrm{cm}^{\nu}$ & $\mathrm{m}^{\lambda} \mu$ & $\mathrm{cm}^{\nu-1}$ \\
\hline 1 & $(350)$ & $\left(2857_{0}\right)$ & - & - & - & - \\
\hline 2 & 360 & $2778_{0}$ & 363 & 27550 & - & - \\
\hline 3 & 370 & 27030 & - & - & 372 & $2688_{0}$ \\
\hline 4 & $(381)$ & $\left(2625_{0}\right)$ & 377 & 26530 & 383 & $2611_{0}$ \\
\hline 5 & 392 & $2551_{0}$ & 388 & $2577_{0}$ & 396 & $2525_{0}$ \\
\hline 6 & 404 & 24750 & 405 & $2469_{0}$ & 407 & $2457_{0}$ \\
\hline 7 & 416 & $2404_{0}$ & 415 & $2410_{0}$ & 420 & $238 l_{0}$ \\
\hline 8 & 425 & $2353_{0}$ & 430 & $2326_{0}$ & $\underline{432}$ & $2315_{0}$ \\
\hline 9 & $(438)$ & $\left(2283_{0}\right)$ & 443 & $2357_{0}$ & 441 & $2268_{0}$ \\
\hline 10 & 450 & $2222_{0}$ & - & - & 448 & $2232_{0}$ \\
\hline 11 & 457 & $2188_{0}$ & 456 & 21930 & 458 & $2183_{0}$ \\
\hline 12 & 472 & 21190 & 472 & 21190 & 478 & $2092_{0}$ \\
\hline 13 & 489 & 20450 & 487 & 20530 & 492 & 20330 \\
\hline
\end{tabular}

In a second paper, Sutton (1949) gave extinction curves of uranyl perchlorate solutions for $\mathrm{pH}$ values up to $\mathrm{pH}$ 9.3. These curves are reproduced in Figure 2.4. During the measurements the solutions showed, no precipitation or formation of a Tyndall cone. However, after several hours' standing, a yellow precipitate formed.

It will be noted that in the main band region (400-450 $\mathrm{m} \mu$ ) absorption as a function of $\mathrm{pH}$ passes through a maximum somewhere in the region of $\mathrm{pH} \mathrm{6-7} \mathrm{and} \mathrm{then} \mathrm{declines} \mathrm{again.} \mathrm{(On} \mathrm{both} \mathrm{sides} \mathrm{of} \mathrm{this} \mathrm{region} \mathrm{absorption} \mathrm{in-}$ creases steadily with $\mathrm{pH}$.) Sutton interpreted this change in the absorption trend as evidence that the third and subsequent steps of hydrolysis are different from the first two; he suggested that they occurred by the addition of hydroxyl ions to the triuranyl complex:

$$
\begin{aligned}
& \mathrm{U}_{3} \mathrm{O}_{8}^{+-t}+\mathrm{OH}^{-} \rightleftharpoons \mathrm{U}_{3} \mathrm{O}_{8} \mathrm{OH}^{+} \\
& \mathrm{U}_{3} \mathrm{O}_{8} \mathrm{OH}^{+}+\mathrm{OH}^{-} \rightleftharpoons \mathrm{U}_{3} \mathrm{O}_{8}(\mathrm{OH})_{2}, \text { etc. }
\end{aligned}
$$


8

Table 2.2

THE MOLAR ABSORPTION COEFFICIENTS OF STOICHIOMETRIC URANYL PERCHLORATE SOLUTION (0.01 TO $0.2 \mathrm{M})^{*}$

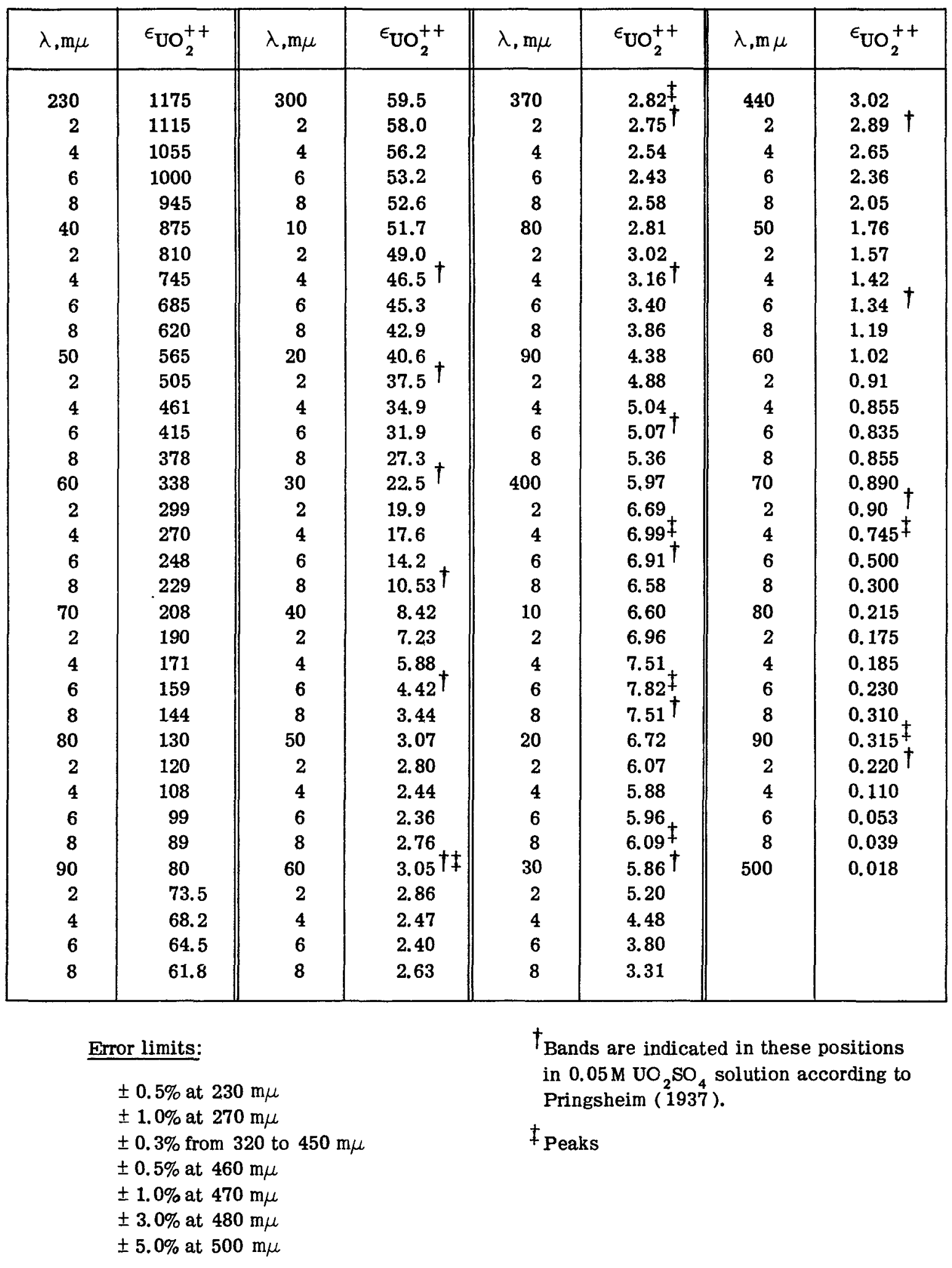




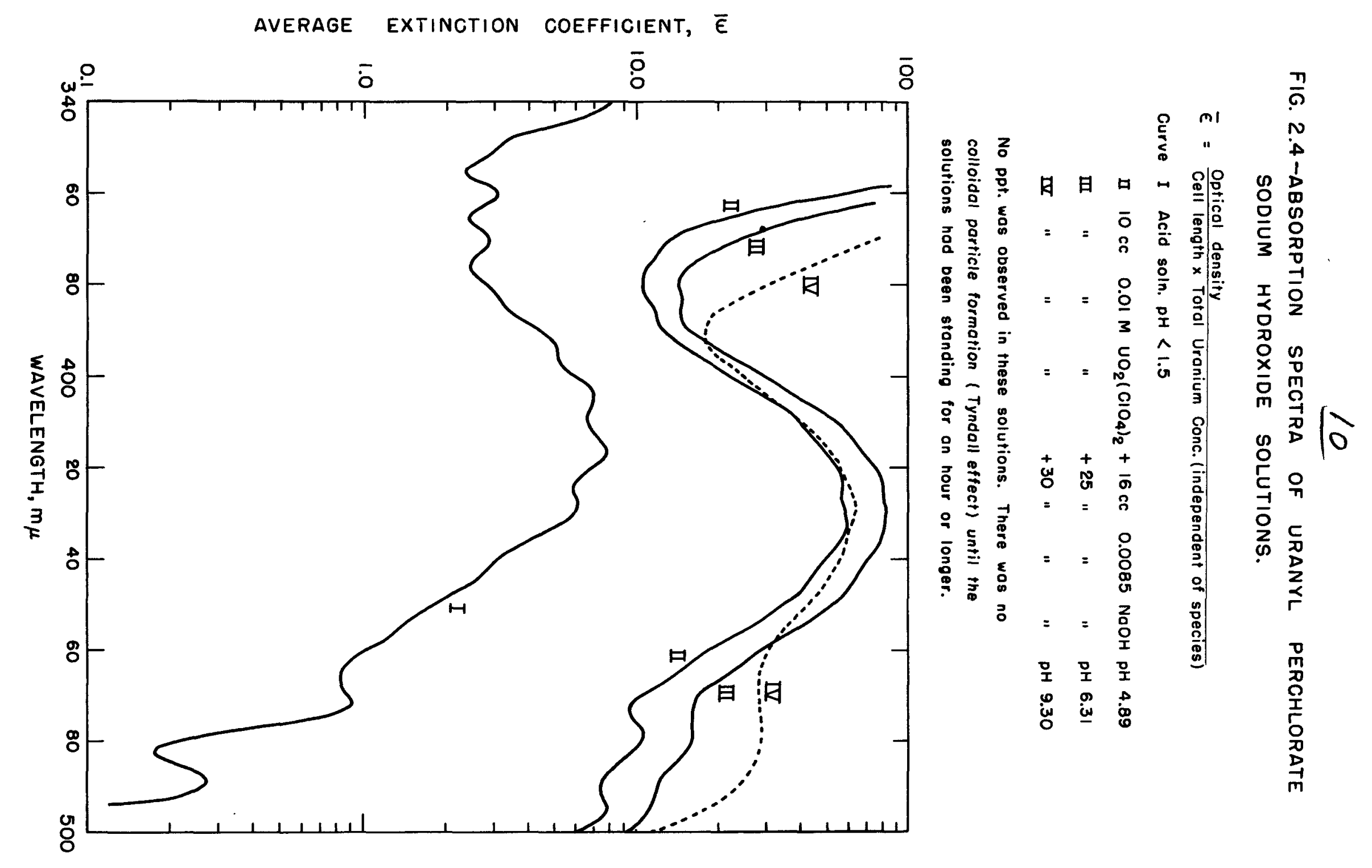


The assumption that $\mathrm{U}_{2} \mathrm{O}_{5}^{++}$and $\mathrm{U}_{3} \mathrm{O}_{8}^{++}$are the first products of hydrolysis of $\mathrm{UO}_{2}\left(\mathrm{ClO}_{4}\right)_{2}$ is confirmed, according to Sutton, by cryoscopic measurements. These show that dissolution of solid $\mathrm{UO}_{3}$ in a $\mathrm{UO}_{2}\left(\mathrm{ClO}_{4}\right)_{2}$ solution occurs without increase in the number of osmotically active particles:

$$
\mathrm{UO}_{2}^{++}+\mathrm{UO}_{3} \rightleftharpoons \mathrm{U}_{2} \mathrm{O}_{5}^{++}
$$

Sutton's second assumption - that the formation of polyuranate complexes linked by $\mathrm{O}$ bridges stops at $\mathrm{U}_{3} \mathrm{O}_{8}^{++}$, and that further complexing occurs by association with $\mathrm{OH}^{-}$ions - was based primarily on nonspectroscopic evidence, such as the shape of the $\mathrm{pH}$ titration curves. Transference experiments confirm the appearance of uranium-bearing anions at alkaline $\mathrm{pH}$ values. Sutton's analysis of the several inflection points on the $\mathrm{pH}$ titration curve of uranyl perchlorate indicated the suc:cessive formation of $\mathrm{U}_{2} \mathrm{O}_{5}^{++}, \mathrm{U}_{3} \mathrm{O}_{8}^{++}, \mathrm{U}_{3} \mathrm{O}_{8} \mathrm{OH}^{+}, \mathrm{U}_{3} \mathrm{O}_{8}(\mathrm{OH})_{2}, \mathrm{U}_{3} \mathrm{O}_{8}(\mathrm{OH})_{3}^{-}$, and $\mathrm{U}_{3} \mathrm{O}_{8}(\mathrm{OH})_{4}^{--}$.

The relative amounts of these species in the uranyl solutions used in Sutton's spectroscopic studies are illustrated by Figure 2.5. According to this figure, spectrum II in Figure 2.4 corresponds to a mixture of $\mathrm{U}_{3} \mathrm{O}_{8} \mathrm{OH}^{+}$ with some $\mathrm{U}_{3} \mathrm{O}_{8}(\mathrm{OH})_{2}$ and a small amount of $\mathrm{U}_{3} \mathrm{O}_{8}(\mathrm{OH})_{3}^{-}$; spectrum III, to a mixture of about equal amounts of $\mathrm{U}_{3} \mathrm{O}_{8}(\mathrm{OH})_{3}^{-}$and $\mathrm{U}_{3} \mathrm{O}_{8}(\mathrm{OH})_{4}^{--}$; and spectrum IV, to a solution containing twice as many divalent as monovalent anions.

Independently of Sutton's measurements, data on the hydrolysis of uranyl salts and its spectroscopic effects have been collected by other investigators. The review article by Dounce, Flagg, Fanta, Tishkoff, and Lan (1949) gives some such data (obtained in connection with toxicological studies) on uranyl acetate solutions. In $0.2 \mathrm{M}$ acetate buffer (HAc $+\mathrm{NaAc}$ ) the absorption spectrum of uranyl acetate shows a change with increasing $\mathrm{pH}$. A curve is given, showing a rapid increase of the ratio $\epsilon_{446 \mathrm{~m} \mu}: \epsilon_{440 \mathrm{~m} \mu}$ between $\mathrm{pH} 3.0$ and $\mathrm{pH} 4.5$. Two absorption curves for the visible region, one obtained at $\mathrm{pH} 3.5$ and one at $\mathrm{pH} 4.7$, indicate that at the higher $\mathrm{pH}, \mathrm{a}$ new, or strongly enhanced, band appears with a peak at $446 \mathrm{~m} \mu$. It can be tentatively indentified with the $443 \mathrm{~m} \mu$ band of $\mathrm{U}_{2} \mathrm{O}_{5}^{++}$in Table $2 . \mathrm{i}$.

(The authors discussed these results in reference to formation of uranyl acetate complexes, but they are more likely to be due to hydrolysis.)

Neuman, Havill, and Feldman (1949) mentioned that the hydrolysis of $\mathrm{UO}_{2}^{++}$(which they interpreted as formation of $\mathrm{UO}_{2} \mathrm{OH}^{+}$) can be detected polarographically only at $\mathrm{pH} \geq 4.2$. The difference between this result and Sutton's data ( $\mathrm{pH} \geq 2.5$, cf. Figure 2.2) may be due in part to the use of more dilute uranyl salt solutions $\left(5 \times 10^{-4} \mathrm{M}\right.$ in polarography vs. $>0.1 \mathrm{M}$ in spectrophotometry); according to Equation (1), the percent hydrolysis should increase in the region of low hydrolysis proportionally to [ $\left.\mathrm{UO}_{2}^{++}\right]\left[\mathrm{H}^{+}\right]^{2}$. 
12

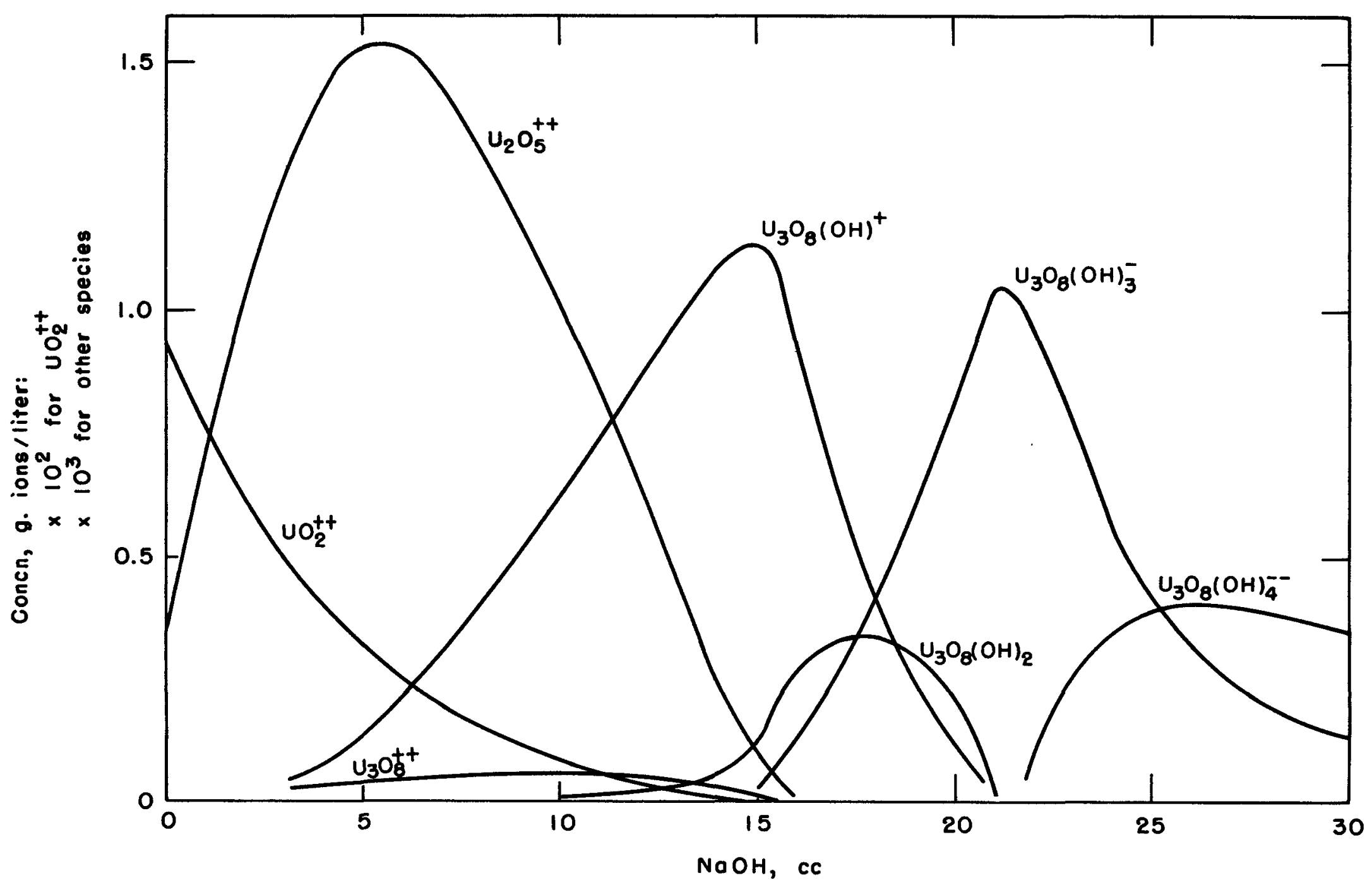

FIG. 2.5-DISTRIBUTION OF MOLECULAR AND IONIC SPECIES IN URANYL SOLUTIONS IN THE PRESENCE OF SODIUM HYDROXIDE (after Sutton, 1949)

$\tilde{N}$ 
The absorption spectrum of uranyl perchlorate solutions was measured also by Ahrland (1949). The curves he gave are very similar to those of Sutton (Figure 2.1); they show the practical independence of $\epsilon$ upon $\mathrm{pH}$ between $\mathrm{pH} 0.1$ and $\mathrm{pH} 2.7$ over the range 240 to $440 \mathrm{~m} \mu$. In the region 240-320 $\mathrm{m} \mu$ (not studied by Sutton) the absorption rises with decreasing wave length, reaching $\epsilon \simeq 30$ at $\lambda=240 \mathrm{~m} \mu$ (cf. Figure 2.3). Shoulders are indicated at 310,275 , and perhaps also at $240 \mathrm{~m} \mu$.

At pH 4.1 absorption curve was measured by Ahrland only above $300 \mathrm{~m} \mu$; it is similar to Sutton's curve for $\mathrm{pH} 4.0$ in Figure 2.1.

Ahrland then proceeded to make $\mathrm{pH}$ measurements in uranyl perchlorate solutions $\left(2 \times 10^{-3}\right.$ to $\left.6 \times 10^{-2} \mathrm{M}\right)$ and calculated from them the average number, $\bar{n}$, of complexly bound $\mathrm{OH}^{-}$ions per uranyl ion at different uranyl salt concentrations and acidities. He concluded, from the shape of $\overline{\mathrm{n}}=\mathrm{f}(\mathrm{pH})$ curves, that polyuranyl complexes are involved in hydrolysis even when the total salt concentration is as low as $5 \times 10^{-3} \mathrm{M}$. By extrapolating $\overline{\mathrm{n}}$ to $\mathrm{l} /\left[\mathrm{H}^{+}\right]=0$ at different total uranyl concentrations, and plotting the result $\left(\mathrm{n}_{0}\right)$ against this concentration, a curve $\bar{n}_{0}=f\left[\mathrm{UO}_{2}^{++}\right]_{0}$ was constructed. Its extrapolated value at $\left[\mathrm{UO}_{2}^{++}\right]_{0}=0$ was used to calculate the complex dissociation constant, $\mathrm{K}_{1}^{1}$, for the first monouranyl complex $\left(\mathrm{UO}_{2}^{++} \mathrm{OH}^{-}\right)$; from its initial slope, it was possible to calculate the complex dissociating constant, $\mathrm{K}_{1}^{\mathrm{n},}$, of the first diuranyl complex, presumably $\mathrm{UO}_{2}^{++} \mathrm{O}=\mathrm{UO}_{2}^{++}$. The socalculated values were as follows:

$$
\begin{aligned}
& \mathrm{K}_{1}^{\prime}=2( \pm 0.4) \times 10^{-5} \\
& \mathrm{~K}_{1}^{\prime \prime}=4( \pm 1) \times 10^{-3}
\end{aligned}
$$

Ahrland thus agrees with Sutton in postulating early formation of diuranyl complexes, but assumes an effective competition by monouranyl complexes, whereas according to Sutton, addition of $\mathrm{OH}^{-}$ions begins to play a role only after $\mathrm{UO}_{2}^{++}$has been complexed to $\mathrm{U}_{3} \mathrm{O}_{8}^{++}$.

The low value of the extinction coefficients of $\mathrm{UO}_{2}^{++}\left(\epsilon_{\max } \simeq 8\right.$, cf. above $)$ indicates a "prohibited" electronic transition [cf. Kasha, (1949)]; the prohibition apparently becomes less strict in the $\mathrm{U}_{3} \mathrm{O}_{8}^{++}$complex, where the extinction coefficient (referred to one $g$ atom uranium!) reaches 240 (even this is low compared to average extinction coefficients in bands corresponding to "permitted" transitions, which are of the order of $10^{4}$, or even $10^{5}$ ). The natural mean lifetime of an excited state corresponding to an absorption band covering the range $400-500 \mathrm{~m} \mu$, with an average decadic molar extinction coefficient $\bar{\epsilon}$, is:

$$
\tau_{0} \simeq \frac{1.05 \times 10^{19}}{\int \epsilon \nu \mathrm{d} \nu} \lambda_{0}^{2}=\frac{2.1 \times 10^{10}}{\bar{\epsilon} \times 1.5 \times 10^{14}}=\frac{1.4 \times 10^{-4}}{\epsilon},
$$

or

$$
\tau_{0}=1.4 \times 10^{-4} \text { for } \epsilon=1 \text { (cf. Figure 2.2) }
$$


14

The "actual" lifetime, $\tau$, as derived from fluorescence measurements, is somewhat longer - about $5 \times 10^{-4} \mathrm{sec}$ - in uranyl solutions as well as in solid uranyl salts (cf. Table 3.1). Since $\tau$ is related to the "natural" lifetime $\tau_{0}$, (to which Equation 14 refers) by the equation

$$
\tau=\phi \tau_{0}
$$

where $\phi$, the quantum yield of fluorescence, is $<1, \tau$ should be shorter than $T_{0}$. This paradox may be due to the fact that $\epsilon$, estimated from the absorption spectrum, includes transitions to several electronic states, while an $\epsilon$ value corresponding to the transition to the $F$ state only should be properly used in Equation (14).

In any case, it seems that the yield of fluorescence in uranyl salt solutions must be high. No experimental determination of this yield has been made, but a rough estimate of $\phi$ for solid potassium uranyl sulfate has in fact indicated a value of the order of 1 . This means incidentally, that in uranyl salt crystals, too, the natural life time of excitation could not be much longer than $5 \times 10^{-4} \mathrm{sec}$, which is two orders of magnitude less than the lifetime calculated by Dieke from intensity measurements of single absorption lines at low temperatures. This discrepancy was pointed out in Chapter 1 . 
15

\section{ABSORPTION SPECTRA OF URANYL IONS COMPLEXED WITH ACID ANIONS}

2.1 Effect of Inorganic Anions on Uranyl Spectrum in Solution - For a long time observations had indicated that the spectrum of aqueous solutions of uranyl salts of strong inorganic acids - nitric, hydrochloric, sulfuric, etc. is affected by the anions present in solution. However, the data have been neither precise nor systematic enough to tell whether these differences indicated the formation of definite complexes. (Thus, marked spectral changes could occur, without the formation of complexes, in consequence of the influence of ions on the bulk properties of the medium, such as its dielectric constant; or as a result of long-range order effects; or, in concentrated solutions, as a result of transient interaction between ions during their encounters.) More recently, the spectra of chloride, sulfate and nitrate solutions have been studied with better precision and interpreted in terms of complex formation.

Many of the older observations dealt only with the position of band peaks; others, in a qualitative way, with changes in the intensity of different bands. The following is a brief review of the results of these studies.

The earliest measurements were assembled and converted to international wave length scale by Kayser, in Vol. 3 of his "Handbook of Spectroscopy" (1905, p. 418). Absorption band peaks are given there for aqueous olutions of uranyl acetate chloride, fluoride, nitrate, (mono)phosphate, and sulfate. As an example, Table 2.3 gives the (corrected) values of the band peaks observed by Morton and Bolton (1873). It shows that, with few exceptions, the bands of the nitrate are located at the shortest waves, followed by those of chloride, sulfate, acetate, fluoride and phosphate.

Table 2.3

ABSORPTION PEAKS OF URANYL SALTS IN AQUEOUS SOLUTION, AT ROOM TEMPERATURE, AFTER MORTON AND BOLTON (1873) CORRECTED BY KAYSER (1905)

\begin{tabular}{|l|c|c|c|c|c|c|c|}
\hline & \multicolumn{9}{|c|}{} & \multicolumn{7}{|c|}{ Band No. } \\
\cline { 2 - 8 } & 4 & 2 & 3 & 4 & 5 & 6 & 7 \\
\hline Nitrate & 488 & 472 & 455 & 440 & 428 & 416 & 404 \\
Chloride & - & 475 & 457 & 440 & 429 & - & - \\
Sulfate & 495.5 & 475 & 457 & 443.5 & 431.5 & 420 & 408 \\
Acetate & 489 & 476 & 461 & 444 & 432 & 420 & 405 \\
Fluoride & - & 478 & 462 & 446 & 433 & 419.5 & 405.5 \\
Mono-phosphate & 506 & 477.5 & 461.5 & 448 & 434.5 & 424 & - \\
\hline
\end{tabular}


For the interpretation of these shifts, the effects of the concentration of anions, and of temperature are significant.

Concentration of the anions can be changed in two ways: either by increasing the concentration of the uranyl salt, or by adding another compound of the same anion, such as an alkali salt, or free acid. These studies are best carried out by substitution, keeping constant the total ionic strength and the acidity. Also, care should be taken to use the $\mathrm{pH}$ range where uranyl ions do not undergo any of the hydrolytic changes described in Section 1 . No such precautions have been taken in the early measurements with which we are dealing now.

Concentration Effects - Knoblauch (1891) found that the positions of the two extreme long wave bands of uranyl nitrate did not change in the concentration range of $\mathrm{UO}_{2}\left(\mathrm{NO}_{3}\right)_{2}$ from $1 \mathrm{M}$ to $3 \times 10^{-3} \mathrm{M}$; the same was found for a 1 to 450 change of concentration of uranyl acetate and a 2500 to 1 change of concentration of uranyl chloride. However, Knoblauch found these bands to be relatively stronger in dilute solution (indicating a deviation from Beer's law).

Jones and Strong (1910a) reproduced photographs of the absorption spectra of aqueous solutions of the following systems:

$$
\begin{aligned}
& \mathrm{UO}_{2} \mathrm{Cl}_{2}(1 ; 0.75 ; 0.5 ; 0.33 ; 0.25,0.16 \text { and } 0.125 \mathrm{~N}) \\
& \mathrm{UO}_{2} \mathrm{Cl}_{2}(0.2 \mathrm{~N})+\mathrm{AlCl}_{3}(2.43 \mathrm{~N}) \\
& \mathrm{UO}_{2} \mathrm{Cl}_{2}(0.2 \mathrm{~N})+\mathrm{ZnCl}_{2} \text { (saturated) } \\
& \mathrm{UO}_{2} \mathrm{Cl}_{2}(0.2 \mathrm{~N})+\mathrm{HCl} \text { (concentrated) }
\end{aligned}
$$

The last three systems were investigated to observe the effect of a high concentration of $\mathrm{Cl}^{-}$ions at constant concentration of $\mathrm{UO}_{2}^{++}$. The absorption bands broadened with increasing $\mathrm{UO}_{2} \mathrm{Cl}_{2}$ concentration (the product concentration times cell depth being constant). The ultraviolet band merges with the nearest violet band.

The positions of the observed band centers (which do not shift significantly with concentration) are shown in Table 2.4. In addition, very narrow, weak bands were noted at 518.5,520,600,602, 604 and $607 \mathrm{~m} \mu$. Addition of calcium chloride caused all bands to broaden. The effect of aluminum chloride was even stronger; the bands shifted to the red by up to $3 \mathrm{~m} \mu$; some increased considerably in intensity. Zinc chloride and concentrated hydrochloric acid produced similar changes, but the red shift was less pronounced with zinc chloride than with aluminum chloride or hydrochloric acid.

Similarly, concentrated nitric acid was found to increase the intensity of $\mathrm{UO}_{2}\left(\mathrm{NO}_{3}\right)_{2}$ bands, but the band shift caused by this acid was toward the violet. 
17

Table 2.4

ABSORPTION BANDS OF $\mathrm{UO}_{2} \mathrm{Cl}_{2}(0.2 \mathrm{~N}$ SOLUTION) AFTER JONES AND STRONG (1910)

\begin{tabular}{|l|l|l|l|l|l|l|l|l|}
\hline $\mathrm{UO}_{2} \mathrm{Cl}_{2}$ & - & 402.5 & 417 & 431.5 & 446 & 456 & 474 & 492 \\
$+\mathrm{ZnCl}_{2}$ (sat.) & - & 411.5 & 424.5 & - & 440 & 460 & 477 & 493 \\
& & & & & diff. & & & \\
$+\mathrm{AlCl}_{3}$ (2N) & 401 & 413.5 & 427 & 442 & 448 & 462 & 479 & 495 \\
$+\mathrm{HCl}$ (conc.) & 401.5 & 415 & 428 & 442 & 448 & 463.5 & 480 & 495 \\
\hline
\end{tabular}

Von Kurelec (1927) measured the shift of the peaks of the first two absorption bands of uranyl nitrate (3.454 $\mathrm{g} \mathrm{UO}_{2}\left(\mathrm{NO}_{3}\right)_{2}$ in $\left.14 \mathrm{cc} \mathrm{H}_{2} \mathrm{O}\right)$, caused by addition of an increasing quantity of sulfuric acid, and found that at $\left[\mathrm{H}_{2} \mathrm{SO}_{4}\right] /\left[\mathrm{HNO}_{3}\right]=1.2$, the bands assumed the positions characteristic of uranyl sulfate. This may indicate replacement of nitrate ions in association with uranyl cations by sulfate ions.

Table 2.5

SHIFT OF $\mathrm{UO}_{2}\left(\mathrm{NO}_{3}\right)_{2}$ ABSORPTION BANDS BY SULFURIC ACID (AFTER VON KURELEC, 1927)

\begin{tabular}{|c|c|c|}
\hline \multirow{2}{*}[\mathrm{H}_{2}\mathrm{SO}_{4}]{, $\mathrm{g} / 14 \mathrm{cc}$ solution } & \multicolumn{2}{|c|}{ Band } \\
\cline { 2 - 3 } & $\mathrm{I}$ & $\mathrm{II}$ \\
\hline 0 & 487.0 & 470.0 \\
0.473 & 489.7 & 473.5 \\
0.788 & 489.6 & 473.6 \\
0.867 & 489.7 & 473.7 \\
0.946 & 489.9 & 473.9 \\
1.576 & 490.3 & 474.4 \\
\hline $\mathrm{UO}_{2} \mathrm{SO}_{4}$ in $\mathrm{H}_{2} \mathrm{O}$ & 490.4 & 474.2 \\
\hline
\end{tabular}

No shift was observed when $0.47 \mathrm{~g} \mathrm{HNO}_{3}$ was added to a solution of $4.57 \mathrm{~g} \mathrm{UO}_{2} \mathrm{SO}_{4}$ in $14 \mathrm{cc} \mathrm{H}_{2} \mathrm{O}$. Addition of nitric acid to $\mathrm{UO}_{2} \mathrm{Cl}_{2}$ solution also was ineffective. This agrees with the assumption that the tendency of uranyl ions for complexing is smaller with $\mathrm{NO}_{3}^{-}$than with $\mathrm{Cl}^{-}$and $\mathrm{SO}_{4}^{-}$ions. 
Only when nitric acid was added to $\mathrm{UO}_{2} \mathrm{Cl}_{2}$ solution in large excess and the mixture heated until gas evolution and brown coloration occurred, did the $\mathrm{UO}_{2}{ }^{++}$bands shift to positions characteristic of a nitrate solution.

When hydrochloric acid was added to uranyl nitrate, a shift similar to that caused by sulfate was observed. At about $[\mathrm{HCl}] /\left[\mathrm{HNO}_{3}\right]=1$, the band reached a position close to that in pure $\mathrm{UO}_{2} \mathrm{Cl}_{2}$ solution.

Pierce (1929) found that chloride in low concentrations has no marked effect on the absorption spectrum of uranyl salt solution, but that saturated potassium chloride changes the spectrum almost as strongly as $0.01 \mathrm{M}$ oxalic acid, indicating the formation of complexes. (It will be noted that quenching of uranyl fluorescence by chloride ions sets in at much lower concentrations and therefore cannot be attributed to complex formation.)

Pringsheim (1937) found similar evidence of interaction of uranyl ions with iodide ions at potassium iodide concentrations of the order of 0.01-0.1M. The absorption coefficient of $0.05 \mathrm{M} \mathrm{UO}_{2} \mathrm{SO}_{4}$ at $365 \mathrm{~m} \mu$ was increased by a factor of 4 by the addition of $0.1 \mathrm{M} \mathrm{KI}$.

The temperature effect on the absorption bands of simple uranyl salts in aqueous solution was first noted by Bremer (1890) [cf. Bremer (1892) and Kayser $\left(1905\right.$, p. 419)]. He found that with $\mathrm{UO}_{2} \mathrm{SO}_{4}$ as well as with $\mathrm{UO}_{2}\left(\mathrm{NO}_{3}\right)_{2}$ solution, heating shifts the band peaks towards the red (by $1.2-1.6 \mathrm{~m} \mu$ between $20^{\circ}$ and $80^{\circ} \mathrm{C}$ ). Morton and Bolton (1873) found the same rule to be followed by several double salts.

Jones and Strong (1910a,b, $1911 \mathrm{a})$ photographed the spectrum of uranyl chloride $(1 \mathrm{~N})$ at $6^{\circ}, 18^{\circ}, 34^{\circ}, 52^{\circ}, 68^{\circ}$ and $82^{\circ} \mathrm{C}$. With increasing temperature, the ultraviolet absorption limit moved toward the visible, from 355 to $370 \mathrm{~m} \mu$; the strong blue-violet band shifted at the same time from 400-445 $\mathrm{m} \mu$ to 395-460 $\mathrm{m} \mu$. In more dilute $(0.0156 \mathrm{~N})$ solution, the temperature effect was much less pronounced. In uranyl nitrate solutions in water ( $1 \mathrm{~N}$ and $0.0156 \mathrm{~N}$ ), the results were similar, with the ultraviolet absorption edge shift $(343 \rightarrow 355 \mathrm{~m} \mu)$ being the most prominent effect. The blue-violet band extended, at $79^{\circ} \mathrm{C}$, from 390 to $445 \mathrm{~m} \mu$.

In uranyl sulfate solutions in water ( $1 \mathrm{~N}$ and $0.0156 \mathrm{~N})$, the ultra-violet edge advanced between $5^{\circ}$ and $84^{\circ} \mathrm{C}$ from 350 to $360 \mathrm{~m} \mu$. The blue-violet band extended at low temperature from 390 to $440 \mathrm{~m} \mu$ (in concentrated solution) or 395 to $445 \mathrm{~m} \mu$ (in dilute solution) and at high temperature from 385 to $445 \mathrm{~m} \mu$ or 390 to $450 \mathrm{~m} \mu$, respectively. Other bands also were shifted by heating: from 457,473 and $491 \mathrm{~m} \mu$, to $459,474.5$ and $492.5 \mathrm{~m} \mu$, respectively, in $\mathbb{N}$ solution; and from 472 and $489.5 \mathrm{~m} \mu$ to 473.5 and $491.5 \mathrm{~m} \mu$, respectively, in $N / 64$ solution.

Jones and Strong.(1911 b, 1912) reproduced the spectra of uranyl nitrate in nitric acid, of uranyl chloride in hydrochloric acid, and of uranyl sulfate in water and in sulfuric acid, at temperatures from $10^{\circ} \mathrm{C}$ to $70-80^{\circ} \mathrm{C}$. The shifts 
in acid solutions were in the same direction (i.e, towards longer wave lengths) as in pure water, but were much less extensive, by about $1 \mathrm{~m} \mu$ in the case of nitrate in nitric acid, and $1.5 \mathrm{~m} \mu$ in that of chloride in hydrochloric acid. Sulfate in sulfuric acid showed a marked shift only in the blue-violet band.

Jones and Guy (1913b) reproduced absorption spectra of $0.2 \mathrm{~N}$ and $0.02 \mathrm{~N}$ uranyl nitrate solutions in water, at temperatures from 20 to $120^{\circ} \mathrm{C}$ and from 20 to $165^{\circ} \mathrm{C}$, respectively. The spectrogram shows general band widening and shift of the centers of some bands towards longer waves with increasing temperature. Broad and diffuse bands appear at the higher temperatures - in $0.02 \mathrm{~N}$ solution at 510,560 and $620 \mathrm{~m} \mu_{0}$

Similar spectrograms were given for 0.166 and $0.2 \mathrm{~N}$ uranyl sulfate in water at $20^{\circ}-185^{\circ} \mathrm{C}$ and $20^{\circ}-165^{\circ} \mathrm{C}$, respectively. The centers of the bands at 477.5 and $432.5 \mathrm{~m} \mu$ moved by as much as $2.5 \mathrm{~m} \mu$ upon heating, while that of the $475.0 \mathrm{~m} \mu$ remained in its original position. The weak and diffuse bands at 510,560 and $620 \mathrm{~m} \mu$ seemed in this case to be unaffected by temperature. These experiments indicated that only very weak complexing occurs between uranyl and nitrate ions and that association is somewhat stronger with sulfate, and still stronger with chloride ions.

Betts and Michels (1949) made the first more precise spectrophotometric study of solutions of uranyl sulfate and uranyl nitrate. They pointed out that definite complex formation with sulfate ions is indicated, in addition to earlier polarographic studies, by the observation that isotopic exchange of uranium between uranyl ions, $\mathrm{U}^{+4}$ ions and $\mathrm{U}^{+6}$ ions is much more rapid in sulfate than in perchlorate solutions. The absence of complexing in the latter solution, shown by Sutton's spectrophotometric study (p.2) was confirmed by Betts and Michels, who extended the range in which the spectrum shows no changes attributable to complexing, to $\left[\mathrm{UO}_{2}^{++}\right]=0.02-0.5 \mathrm{M}$ and $\left[\mathrm{HClO}_{4}\right]=2-6 \mathrm{M}\left(\right.$ at $\left.\left[\mathrm{H}^{+}\right]=2 \mathrm{M}\right)$.

In sulfate solutions (also at $\left[\mathrm{H}^{+}\right]=2 \mathrm{M}$ ), with a total ionic strength of $\eta=2.65$ (sulfuric acid being treated as a monobasic acid), comparison of absorption curves of solutions with a constant value of $\left(\left[\mathrm{UO}_{2}^{++}\right]+\left[\mathrm{HSO}_{4}^{-}\right]\right)$ $(=0.240 \mathrm{M})$, but variable ratio $\left[\mathrm{UO}_{2}^{+}\right] /\left[\mathrm{HSO}_{4}^{-}\right]$, revealed an increase of average molar extinction coefficients (in the range 420-450 $\mathrm{m} \mu$ ) with increasing proportion of uranyl ions, $x=\left[\mathrm{UO}_{2}^{+}\right] /\left(\left[\mathrm{UO}_{2}^{+}\right]+\left[\mathrm{HSO}_{4}^{-}\right]\right)$, reaching a peak at the ratio $\underline{x}=0.5$ and decreasing at $\underline{x}>0.5$. According to Job, this indicates the formation of a one-to-one uranyl bisulfate complex. The effect of $\mathrm{H}^{+}$concentration on the results indicated that the complexing reaction is:

$$
\mathrm{UO}_{2}^{++}+\mathrm{HSO}_{4}^{-} \rightleftharpoons \mathrm{UO}_{2} \mathrm{SO}_{4}+\mathrm{H}^{+} \text {, }
$$

rather than:

$$
\mathrm{UO}_{2}^{++}+\mathrm{HSO}_{4}^{-} \rightleftharpoons \mathrm{UO}_{2} \mathrm{HSO}_{4}^{+}
$$


The spectrum of the species $\mathrm{UO}_{2} \mathrm{SO}_{4}$, derived from the se experiments, is shown in Figure 2.6. The equilibrium constant is:

$$
\mathrm{K}\left(\mathrm{UO}_{2} \mathrm{SO}_{4}\right)=\left(\left[\mathrm{UO}_{2} \mathrm{SO}_{4}\right] /\left[\mathrm{UO}_{2}^{++}\right]\left[\mathrm{HSO}_{4}^{-}\right]\right)=2.50 \pm 0.17(\mathrm{~mole} / \mathrm{l})^{-1} \text {, }
$$

for $\eta=3.48$. This value was derived from the spectra of two solutions, both $0.02 \mathrm{M}_{\text {in }} \mathrm{HSO}_{4}^{-}$; it was confirmed by calculating extinction values for other mixtures of same ionic strength and acidity, and comparing them with experimental values.

A similar study of the uranyl nitrate system led to Figure 2.7 for the spectrum of the species $\mathrm{UO}_{2} \mathrm{NO}_{3}^{+}$, and to an equilibrium constant

$$
\mathrm{K}\left(\mathrm{UO}_{2} \mathrm{NO}_{3}^{+}\right)=\frac{\left[\mathrm{UO}_{2} \mathrm{NO}_{3}^{+}\right]}{\left[\mathrm{UO}_{2}^{++}\right]\left[\mathrm{NO}_{3}^{-}\right]}=0.21 \pm 0.01(\mathrm{~mole} / \ell)^{-1}
$$

at $\left[\mathrm{H}^{+}\right]=2.00$, and $\eta=5.38$ (equilibrium constant calculated from the spectra of two solutions with $\left[\mathrm{UO}_{2}^{++}\right]=0.0605 \mathrm{M}$, and $\left[\mathrm{NO}_{3}^{-}\right]=1.28$ and $2.56 \mathrm{M}$, respectively; checked by comparing calculated and observed spectra of other solutions of same acidity and ionic strength).

In looking for higher nitrate complexes at the higher concentrations, Betts and Michels found only slight deviations of observed from the calculated spectra at $\left.\eta=7.05\left[\mathrm{~K}_{\left(\mathrm{UO}_{2} \mathrm{NO}\right.}\right)=0.270 \pm 0.007\right]$. The se deviations were in the direction of stronger absorption, as expected for a higher complex but they were so small that Betts and Michels considered them to be due to slight variations of $\mathrm{K}$ with [ $\mathrm{UO}_{2}^{+}$] (at constant $\eta$ ), rather than to the formation of deeper-colored higher complexes.

According to a note by Arden (1949), potentiometric and conductometric measurements indicate the formation of the following complexes in uranyl sulfate solutions:

$$
\mathrm{UO}_{2} \mathrm{SO}_{4} ; \mathrm{U}_{3} \mathrm{O}_{3}^{+} ;\left(\mathrm{UO}_{2} \mathrm{OH}\right)_{2} \mathrm{SO}_{4} ; \mathrm{U}_{3} \mathrm{O}_{8} \mathrm{OH}^{+} ; \mathrm{UO}_{2}(\mathrm{OH})_{2} ; \mathrm{U}_{3} \mathrm{O}_{8}(\mathrm{OH})_{2}
$$

The formation of a trinitro complex from uranyl nitrate and concentrated nitric acid in certain organic solvents will be described in Section 3 of this chapter.

Ahrland (1951 c) measured extinction curves of $0.033 \mathrm{M}$ (or $0.015 \mathrm{M}$ ) $\mathrm{UO}_{2}\left(\mathrm{ClO}_{4}\right)_{2}$ solutions in $0.25 \mathrm{M}$ (or $\left.0.10 \mathrm{M}\right) \mathrm{HClO}_{4}$, to which $\mathrm{NaCl}(0.25-0.75 \mathrm{M}$ ), $\mathrm{NaBr}(0.75 \mathrm{M})$ or $\mathrm{NaNO}_{3}(0.75 \mathrm{M})$ was added, the ionic strength being adjusted to $\eta=1.0$ by $\mathrm{NaClO}_{4}$. The curves showed slight, but real differences, indicative of weak complexing. Assuming a $1-1$ complex only, its equilibrium constant could be calculated, for uranyl chloride, as

$$
\mathrm{K}_{1}=\frac{\left[\mathrm{UO}_{2} \mathrm{Cl}^{+}\right]}{\left[\mathrm{UO}_{2}^{+}\right]\left[\mathrm{Cl}^{-}\right]}=0.5 \pm 0.3(\mathrm{~mole} / \mathrm{l})^{-1} \quad\left(20^{\circ} \mathrm{C}\right)
$$




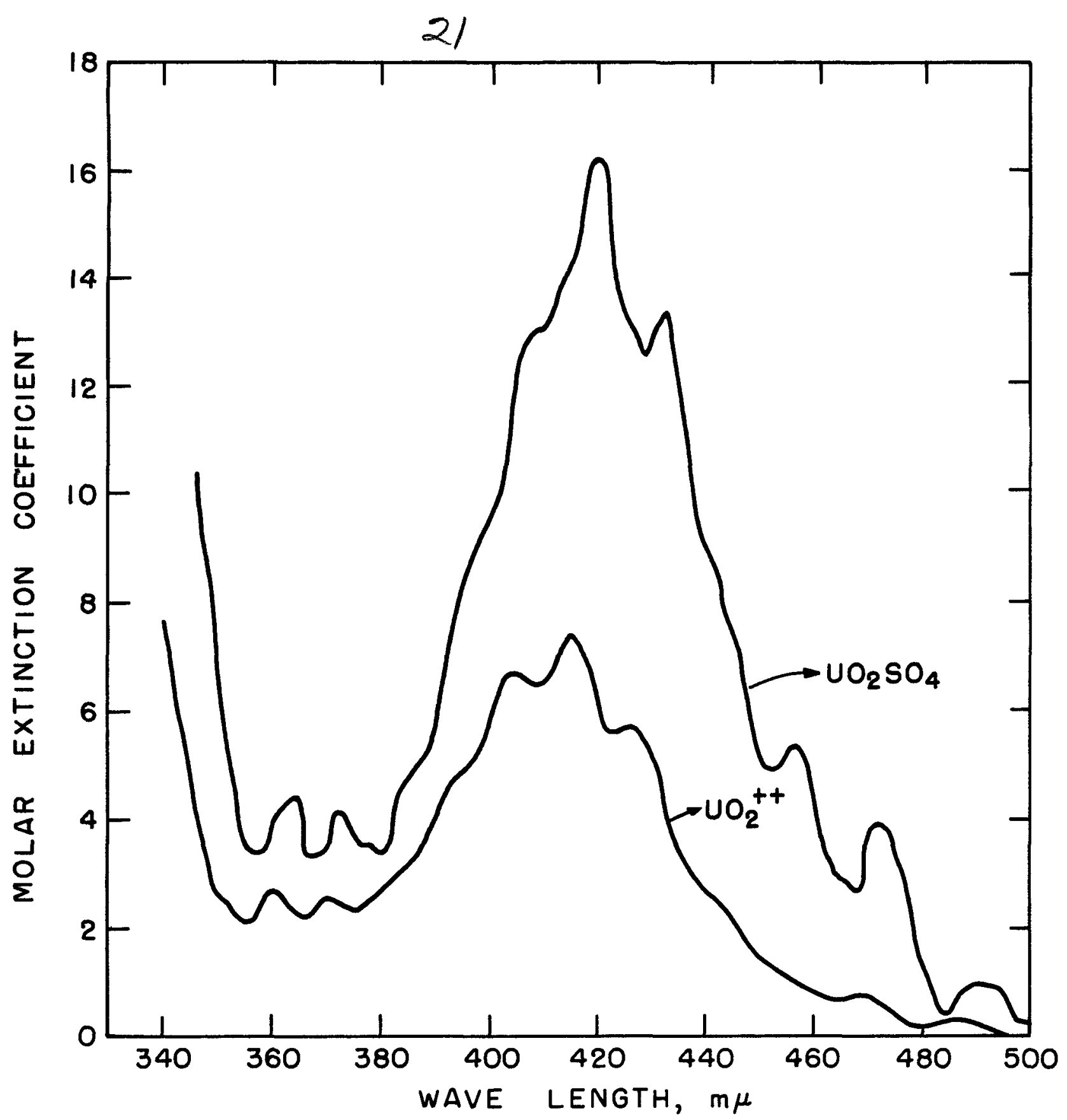

FIG. 2.6- ABSORPTION SPECTRUM OF THE COMPLEX $\mathrm{UO}_{2} \mathrm{SO}_{4}$ (after Betts and Michels, 1949). 


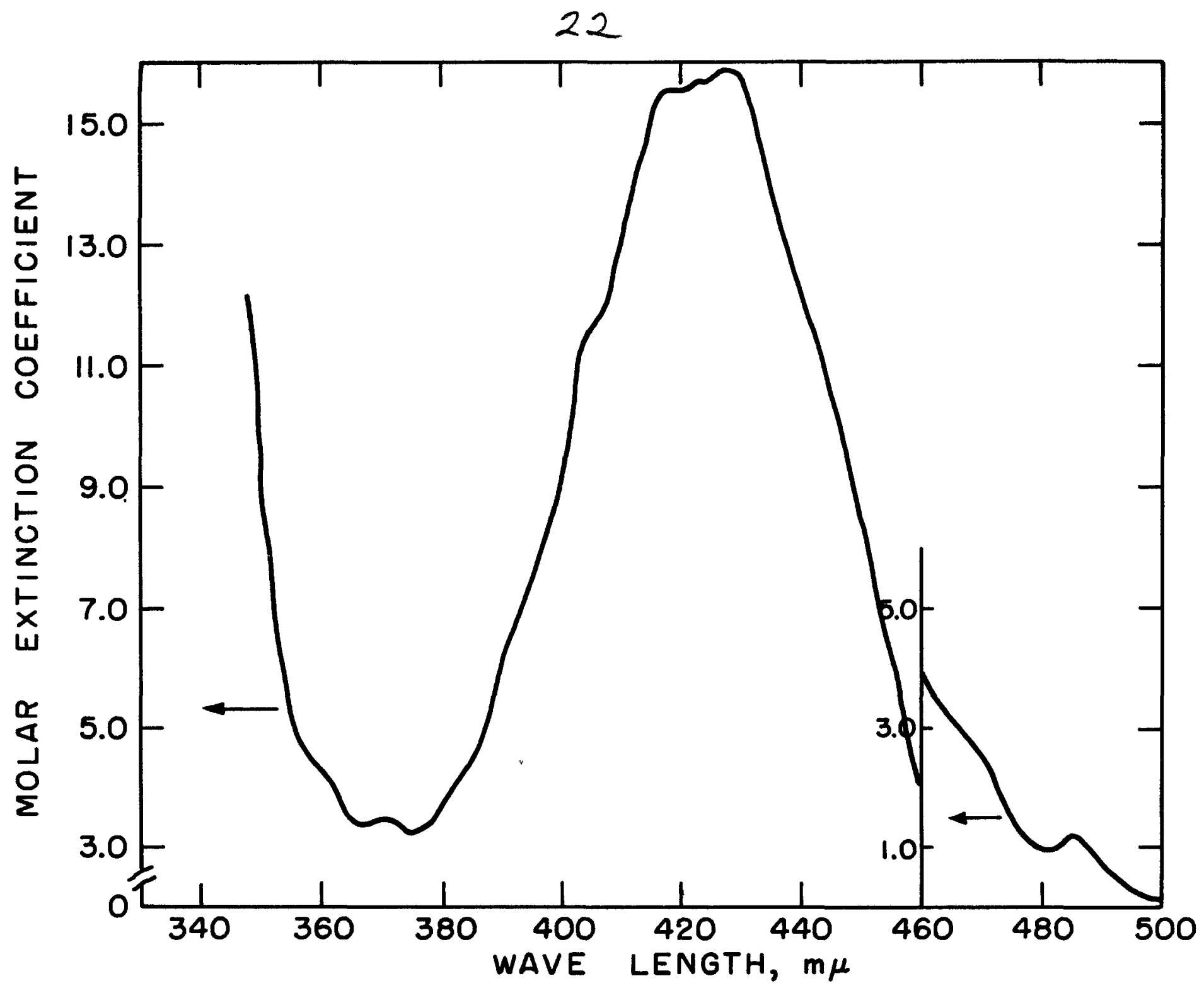

FIG. 2.7 - ABSORPTION SPECTRUM OF $\mathrm{UO}_{2} \mathrm{NO}_{3}^{+}$.

N 


\section{3}

For all three salts, the first complexing constant at $20^{\circ} \mathrm{C}$ was determined potentiometrically; the resulting values were $0.8,0.5$, and $0.5( \pm 0.2)$ (mole $/ \ell)^{-1}$ for the chloride, bromide, and nitrate, in this order. The last value can be compared with Betts and Michels' result $(0.21 \pm 0.01$ at $\eta=$ 5.38 and $25^{\circ} \mathrm{C}$ ).

A similar study of sulfate (Ahrland, 1951b) gave Figure 2.8A for the absorption spectra at different sulfate concentrations, and Figure $2.8 \mathrm{~B}$ for the molar absorption coefficient at $310 \mathrm{~m} \mu$ as function of [sulfate] and three different [uranyl] values. Again, only monouranyl complexes of $\mathrm{UO}_{2}^{++}$with $\mathrm{SO}_{4}^{--}$are indicated, with the association constants

$$
K_{1}=56 \pm 6(\text { mole } / \ell)^{-1} \quad K_{2}=450 \pm 50(\text { mole } / \ell)^{-2}
$$

The first constant, valid at $20^{\circ} \mathrm{C}$ and $\eta=1.0$, can be compared with Betts and Michels' value of $59.5 \pm 4(\text { mole } / \ell)^{-1}$. (Ahrland makes objections against the method used by Betts and Michels.)

The association constants derived from potentiometric methods were:

$$
\begin{aligned}
& K_{1}=50 \pm 10(\text { mole } / \ell)^{-1} \\
& K_{2}=350 \pm 150(\text { mole } / \ell)^{-2} \\
& K_{3}-2500 \pm 1000(\text { mole } / \ell)^{-3}
\end{aligned}
$$

Association constants of mixed acetate-sulfate complexes, $\mathrm{UO}_{2}^{++} \mathrm{Ac}^{-} \mathrm{SO}_{4}^{--}$and $\mathrm{UO}_{2}^{++} \mathrm{Ac}_{2}^{--} \mathrm{SO}_{4}^{--}$, also were estimated potentiometrically.

2.2 Complexing with Organic Ions - The spectroscopic evidence of uranyl ion complexing with anions of organic acids is much stronger than in the case of mineral acids but here, too, older data are insufficient for satis factory quantitative analysis, and new systematic measurements, under controlled conditions of acidity and ionic strength, are needed.

Early data on the absorption spectrum of uranyl acetate in the visible range were mentioned on p. 15 (cf. Table 2.3). Jones and Strong $(1910 \mathrm{a}, 1911 \mathrm{~b}$ ) noted that the long-wave edge of the blue-violet absorption band of a $0.04 \mathrm{M}$ solution of this salt moved from $450 \mathrm{~m} \mu$ at $6^{\circ} \mathrm{C}$ to $460 \mathrm{~m} \mu$ at $75^{\circ} \mathrm{C}$.

Henri and Landau (1914) measured the absorption coefficients of several uranyl salt solutions in the medium ultraviolet (236-330 m $\mu$ ). The results are shown in Table 2.6. A substantial increase in absorption is caused by the addition of oxalate or acetate. Henri and Landau saw in this an example of "photochemical exaltation"; according to this concept, the absorption of light by a mixture of molecular species that can react with each other photochemically is stronger than the sum of the absorption of the components. 


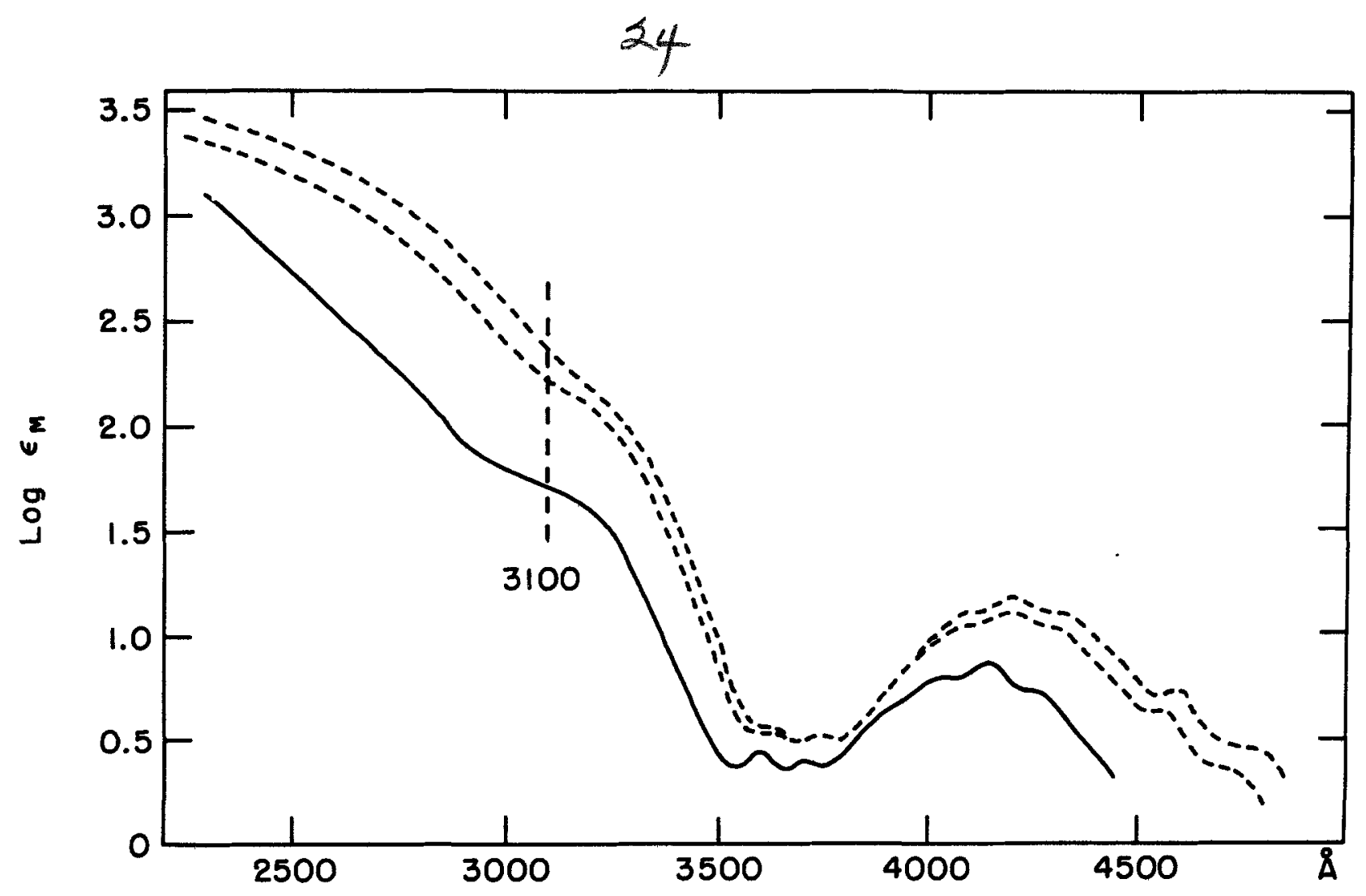

Figure $2.8 \mathrm{~A}$

MOLAR DECADIC EXTINCTION CURVES OF URANYL SULFATE COMPLEXES (AFTER AHRLAND, $195 \mathrm{lb}$ ). SOLID LINE: URANYL IONS (FREE). DASHED LINES: $\left[\mathrm{UO}_{2}^{++}\right]_{0}=0.01 \mathrm{M} ;[\text { SULFATE }]_{0}=0.05 \mathrm{M}$ (LOWER CURVE), $0.2 \mathrm{M}$ (UPPER CURVE). $\left[\mathrm{UO}_{2}^{++}\right]_{0}=$ TOTAL CONCENTRATION OF FREE AND BOUND URANYL. [SULFATE $]_{0}=$ TOTAL CONCENTRATION OF SULFATE USED (URANYL SULFATE + SODIUM SULFATE). A SMALL CORRECTION IS MADE FOR ASSOCIATION OF $\mathrm{SO}_{4}^{--}$IONS WITH $\mathrm{H}^{+}$IONS (ENOUGH PERCHLORIC ACID IS ADDED TO SUPPRESS HYDROLYSIS OF URANYL IONS). IONIC STRENGTH $\eta=1.0$ ADJUSTED BY $\mathrm{NaClO}_{4}$. 


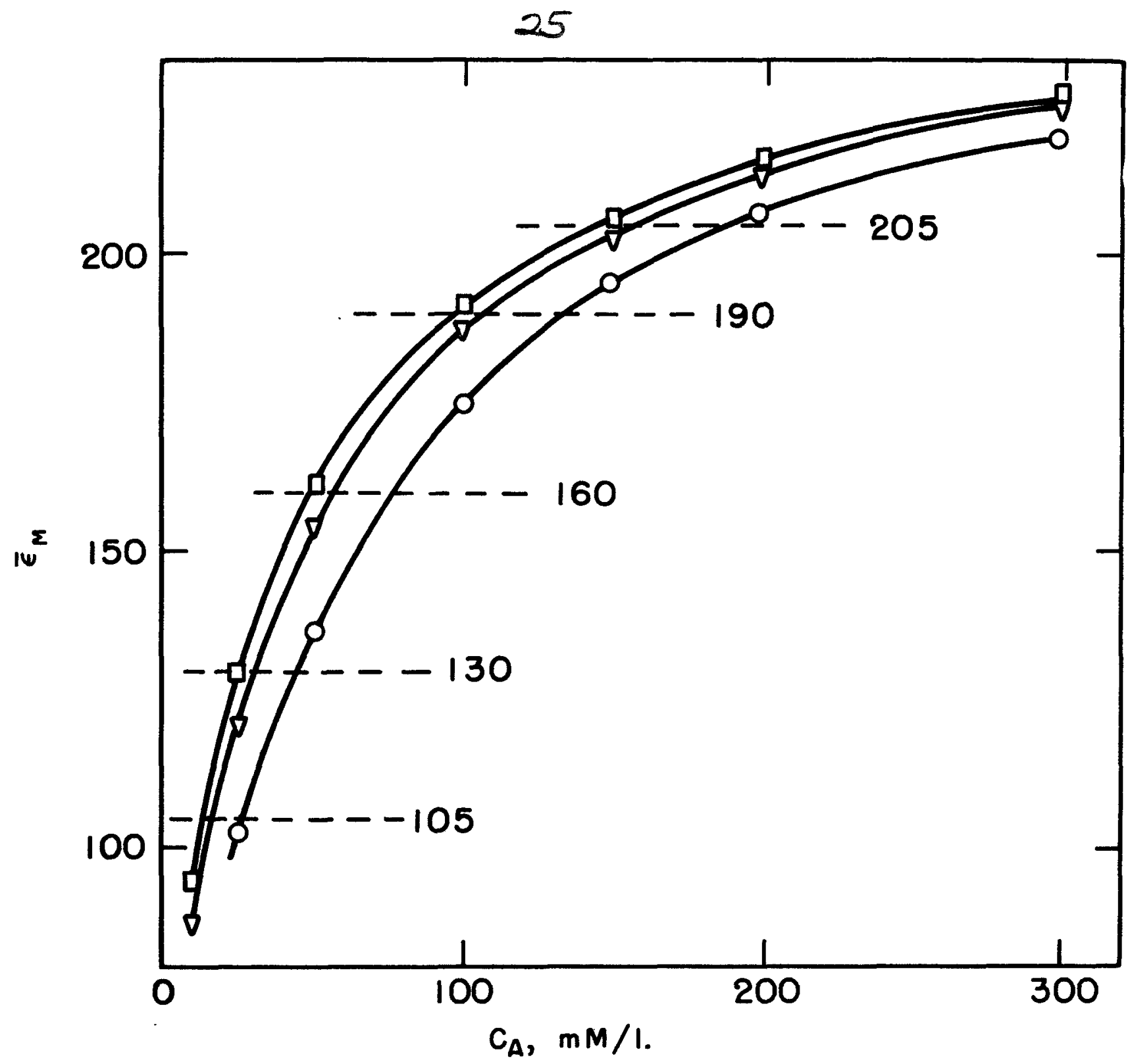

Figure 2.8B

AVERAGE MOLAR DECADIC EXTINCTION COEFFICIENT AT $310 \mathrm{~m} \mu$ IN URANYL + SULFATE SOLUTION AS FUNCTION OF TOTAL SULFATE CONCENTRATION $C_{A}$ (FREE SULFATE IONS + SULFATE IONS COMPLEXED WITH URANYL). $O\left[\mathrm{UO}_{2}^{++}\right]_{0}=0.030 \mathrm{M} . \nabla\left[\mathrm{UO}_{2}^{++}\right]_{0}=0.010 \mathrm{M}$. $\square\left[\mathrm{UO}_{2}^{++}\right]_{0}=0.003 \mathrm{M}$. HORIZONTAL LINES CUT THE SEVERAL CURVES AT POINTS CORRESPONDING TO CONSTANT CONCENTRATION OF FREE ANIONS. 


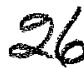

Table 2.6

EFFECT OF DIFFERENT ANIONS ON THE ABSORPTION COEFFICIENTS OF

URANYL IONS IN ULTRAVIOLET (AFTER HENRI AND LANDAU, 1914)

$\log _{10}\left(\mathrm{I}_{0} / \mathrm{I}\right)=\operatorname{ecd}$

$\mathrm{c}$ in mole U/liter. Acid concentration not specified.

\begin{tabular}{|l|r|r|r|r|r|r|r|r|r|r|}
\hline \multirow{2}{*}{ Solution Contains } & \multicolumn{8}{|c|}{ Wavelength, m $\mu$} \\
\cline { 2 - 10 } & 236 & 243.5 & 251.0 & 259.2 & 272.4 & 289.5 & 300.1 & 307.6 & 318.6 & 330.6 \\
\hline $\mathrm{UO}_{2}\left(\mathrm{NO}_{3}\right)_{2}$ & 2020 & 1350 & 675 & 540 & 295 & 160 & 125 & 108 & 65 & 27 \\
$\mathrm{UO}_{2} \mathrm{SO}_{4}$ & 1350 & 1000 & 720 & 545 & 375 & 200 & 108 & 81 & 54 & - \\
$\mathrm{UO}_{2} \mathrm{Cl}_{2}$ & 1050 & 890 & 540 & 490 & 320 & 275 & 170 & - & - & - \\
$\mathrm{UO}_{2}\left(\mathrm{CH}_{3} \mathrm{COO}\right)_{2}$ & 2200 & 1825 & 1575 & 1300 & 970 & 810 & 630 & 500 & 320 & 210 \\
$\mathrm{UO}_{2}\left(\mathrm{NO}_{3}\right)_{2}+\mathrm{H}_{2} \mathrm{C}_{2} \mathrm{O}_{4}$ & - & - & 2480 & 1950 & 1390 & 780 & 540 & 440 & 300 & - \\
$\mathrm{UO}_{2} \mathrm{SO}_{4}+\mathrm{H}_{2} \mathrm{C}_{2} \mathrm{O}_{4}$ & 3225 & 2850 & 2445 & 2030 & 1440 & 640 & 410 & 280 & 190 & - \\
$\mathrm{UO}_{2} \mathrm{Cl}_{2}+\mathrm{H}_{2} \mathrm{C}_{2} \mathrm{O}_{4}$ & - & - & 1610 & 1380 & 1010 & 585 & 370 & 260 & 180 & - \\
$\mathrm{UO}_{2}\left(\mathrm{CH}_{3} \mathrm{COO}\right)_{2}$ & & & & & & & & & & \\
$+\mathrm{H}_{2} \mathrm{C}_{2} \mathrm{O}_{4}$ & 3160 & 2670 & 2280 & 1840 & 1230 & - & - & - & - & - \\
$\mathrm{UO}_{2} \mathrm{C}_{2} \mathrm{O}_{4}$ & 2770 & 2380 & 1990 & 1690 & 1230 & 580 & 435 & 290 & 165 & 120 \\
\hline $\mathrm{Oxalic} \mathrm{Acid}^{*}$ & 88 & 64 & 57 & & 49 & 22 & 5 & 2 & - & - \\
\hline
\end{tabular}

* Figures in this row show how much light oxalate alone would have absorbed at the different wave lengths. Henri and Landau noted that $\epsilon$ (oxalate), added to $\epsilon\left(\mathrm{UO}_{2}\left(\mathrm{NO}_{3}\right)_{2}\right)$ (top row in Table 2.6) is smaller than $\epsilon$ of the mixture $\left(\mathrm{UO}_{2}\left(\mathrm{NO}_{3}\right)_{2}+\right.$ oxalate), and considered this difference as "photochemical exaltation"; we interpret it as evidence of complex formation.

A parallelism between enhanced absorption and photochemical reactivity is in fact possible, but the latter cannot be considered as cause of the former. What is essential is that the two components form a more or less stable complex. Light absorption can then cause the transfer of an electron from one part of the complex (e.g., the anion), to another part (e.g., the cation); the absorption band is an "electron transfer band." Such a transfer is equivalent to an internal oxidation-reduction; the complex may then - but does not need to - dissociate into an oxidized and a reduced product (e.g., into a reduced uranyl ion and an oxidized oxalate ion). If the anion-cation electron transfer band lies in the same region as the absorption bands of one (or both) of the separate ions, the effect of complexing will be to enhance absorption in this region. Whether or not, the lifting of the electron into the 


\section{7}

transfer band will lead to a photochemical change depends on the amount of vibrational energy of a certain type required for this change and the probability of conversion of electronic excitation energy into vibrational energy of this kind. This probability may be large or small, both in photochemically unstable and in photochemically stable complexes.

The change of absorption spectrum observed by Henri and Landau upon mixing of uranyl salts with acetic or oxalic acid seems to consist in a strong general enhancement of absorption, rather than a shift of the absorption band; this is a reason for attributing it to a new excited state, not possessed by the separate ions. Often, however, the absorption bands of complexes are not much more intense than those of the non-complexed ions, but only appear so because they shifted towards longer waves, thus enhancing the absorption in the visible and near ultraviolet. In this case, one does not need to postulate a new electronic level in the complex, but can assume that complexing merely lowers the energy of an excited state belonging to one of the free ions. In further developing the picture, we note that "free ions," in the case of aqueous solutions, means hydrated ions; some of their strong ultraviolet absorption bands may be (and probably are) due to the transfer of an electron from the hydration sphere to the central cation, or vice versa. (The much weaker bands in the visible and near ultraviolet, on the other hand, are likely to be caused by prohibited transitions within the ion itself.) The effect of complexing with an anion is to introduce the latter into the hydration sphere of the cation. This may merely make the electron transfer to or from the water envelope easier (thus shifting the absorption band towards longer waves); or it may permit a new kind of transfer, in which the electron originates (or ends), not in the hydration sphere, but in the anion. This new electronic transition produces a general enhancement of absorption in the region of the new electron transfer band.

With the se general remarks concerning enhanced absorption of complex ions (compared to that of non-complexed, hydrated ions) prompted by Henri and Landau's "photochemical exaltation" concept, we return to the experimental data obtained with uranyl ions and organic acids.

Somewhat more systematic measurements than those of Henri and Landau were carried out by Ghosh and Mitter (1928). They observed the enhancement of ultraviolet absorption of $5 \times 10^{-4} \mathrm{M}$ and $10 \times 10^{-4} \mathrm{M}$ uranyl solutions by the addition of various organic acids (0.005M to $1 \mathrm{M})$, and found effects which they attributed to the formation of $1-1$ complexes between uranyl ions and the acid, with an equilibrium constant $\mathrm{K}_{\mathrm{c}}$ :

$$
\mathrm{K}_{\mathrm{C}}=\frac{\left[\mathrm{UO}_{2}^{++} \mathrm{A}\right]}{\left[\mathrm{UO}_{2}^{++}\right][\mathrm{A}]}=\frac{[\mathrm{C}]}{\left([\mathrm{U}]_{0}-[\mathrm{C}]\right)\left([\mathrm{A}]_{0}-[\mathrm{C}]\right)}
$$

where [C] is the concentration of the complex, and [U] $]_{0}$ and $[A]_{0}$ are the total concentrations of uranyl salt and acid, respectively. 
28

Spectroscopic evidence of the formation of a uranyl tartrate complex was obtained by Hakomori (1927); he noted that increased addition of Rochelle salt to $0.02 \mathrm{~N}$ uranyl sulphate'solution causes the ultraviolet absorption to move from 335 to $360 \mathrm{~m} \mu$, when a $1: 1$ ratio is reached, and then to recede again.

In analogy with the hydrolysis equilibria discussed in Section 1 , the possibility of formation of polyuranyl ions should not be forgotten. However, Ahrland $(1949,1951)$ found, with several inorganic $\left(\mathrm{HCl}, \mathrm{HBr}, \mathrm{HNO}_{3}, \mathrm{H}_{2} \mathrm{SO}_{4}\right)$ and organic (acetic, monochloracetic, thiocyanic) acids, no evidence of complexes containing more than one uranyl ion. Even considering $1-1$ complexes only, Equation (17) is unsatisfactory, because [A] denotes total acid, no distinction being made between acid anions and neutral acid molecules. Even if relatively few free ions are present in weak acids at $A_{0} \geq 0.1 \mathrm{M}$, the most important complex species may still be that containing anions, e.g.,

$$
\mathrm{UO}_{2}^{++}+\mathrm{HCOO}^{-}=\mathrm{UO}_{2} \mathrm{HCOO}^{+}
$$

Equation (17) must, therefore, be replaced by one involving the dissociation constant of the acid, $\mathrm{D}$, in addition to the complexing constant $\mathrm{K}$ :

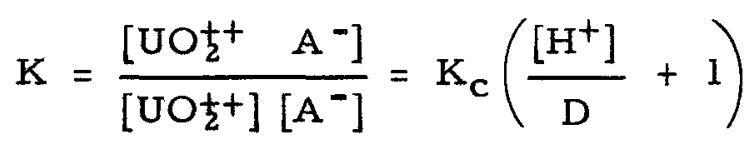

When acid dissociation is practically complete (i.e., when $D>>\left[\mathrm{H}^{+}\right]$) we have:

$$
\mathrm{K} \simeq \mathrm{K}_{\mathrm{c}}
$$

and Ghosh and Mitter's procedure becomes admissible (leaving out "second order" effects, such as the -generally quite considerable - dependence of the complexing constant on ionic strength). In the case of weak dissociation $\left(\left[\mathrm{H}^{+}\right]>\mathrm{D}\right)$, on the other hand, we have

$$
\mathrm{K} \simeq \mathrm{K}_{\mathrm{C}} \frac{\left[\mathrm{H}^{+}\right]}{\mathrm{D}}, \text { or } \mathrm{K}_{\mathrm{c}} \simeq \frac{\mathrm{KD}}{\left[\mathrm{H}^{+}\right]} \simeq \mathrm{K} \sqrt{\frac{\mathrm{D}}{\mathrm{A}_{0}}}
$$

and thus see that Ghosh and Mitter's "constant," $K_{C}$, cannot remain constant except in buffered solutions $\left(\left[\mathrm{H}^{+}\right]=\right.$const.), while in the absence of a buffer, the observed values of the "constant" $\mathrm{K}_{c}$ will decrease with increasing concentration of the acid. In the region of very weak dissociation, $\mathrm{K}_{\mathrm{c}}$ will be inversely proportional to $\sqrt{\mathrm{A}_{0}}$.

Ghosh and Mitter's $\mathrm{K}_{\mathrm{c}}$ calculations could have thus given a correct picture of the relative strength of complexing with different acids only if their measurements would have been made in the region of approximately complete dissociation; in fact, however, they were made mostly in the region 


\section{9}

of weak dissociation, where the apparent "complexing constants,", $\mathrm{K}_{\mathrm{c}}$, are smaller the weaker the acid. With very weak dissociation, when Equation (20) is valid, $K_{c} / K$ will be proportional to $\sqrt{D}$ at any given concentration of the added acid; in other words, of two acids with equal true complexing constants, $\mathrm{K}^{\prime}$ and $\mathrm{K}^{\prime \prime}$, the one with the higher dissociation constant, $\mathrm{D}$, will appear to form more stable complexes:

$$
K_{c}^{\prime} \simeq \sqrt{\frac{D^{\prime}}{D^{\prime \prime}}} K_{c}^{\prime \prime}
$$

One can imagine the acid anions as having a choice of complexing, either with $\mathrm{H}^{+}$ions or with $\mathrm{UO}_{2}^{++}$ions. The tendency for complexing with hydrogen ions is generally greater than that for complexing with uranyl ions ( $\mathrm{K}$ is smaller than $\mathrm{I} / \mathrm{D} !)$. The number of $\mathrm{H}^{+}$ions available (i.e., in practice, in unbuffered solution, the total acid concentration, [A] $]_{0}$ ) was in Ghosh's experiments much higher than the total number of available uranyl ions. Therefore, the concentration of free acid anions was determined mainly or exclusively by $[A]_{0}$ and $D$, and the concentration of uranyl complexes was in its turn determined by the concentration of free acid anions.

Similarly, the uranyl ions have a choice of association either with the acid anions or with the anions of water $\left(\mathrm{OH}^{-}\right.$and $\left.\mathrm{O}^{--}\right)$.

Improved calculation should take into consideration also the hydrolysis equilibria of the uranyl ion, described in Section 1, which become important at $\mathrm{pH}>2$. Finally, the equilibrium constants depend on ionic strength, so that measurements should be made at known and constant ionic strength.

When Equation (17) is valid, the complexing constant, $K_{c}$, can be calculated, together with the absorption coefficient, $\epsilon_{\mathrm{c}}$, of the complex $\left[\mathrm{UO}_{2}^{++} \mathrm{A}\right.$ ], by measuring the absorption coefficient $\bar{\epsilon}$ (the average molar absorption coefficient referred to the total uranyl content) at a given wave length, $\lambda$, with two different concentrations of total added. acid, $A_{0}$.

Each measured value of $\bar{\epsilon}$ can be expressed by an equation

$$
\bar{\epsilon}=\frac{[\mathrm{C}]\left(\epsilon_{\mathrm{c}}-\epsilon_{\mathrm{u}}\right)+[\mathrm{U}]_{\mathrm{o}} \epsilon_{\mathrm{u}}}{[\mathrm{U}]_{\mathrm{o}}}
$$

with two unknowns: [C] = concentration of complex, and $\epsilon_{c}=$ absorption coefficient of complex, while $\epsilon_{\mathrm{u}}$, the absorption coefficient of non-complexed uranyl ions, can be presumed to be known from measurements made without added acid. Two such equations, together with two equations of type (17) for the two concentrations $A_{0}$, provide four equations with four unknowns, which can be solved.

Ghosh and Mitter tabulated $\mathrm{K}_{\mathrm{c}}$ values (Table 2.7) and the absorption coefficients, $\epsilon_{\mathrm{c}}$ (Table 2.8) calculated in this way for the several acids they have studied. However, closer scrutiny reveals, in the first place, that the 
values designated by them as "absorption coefficients of the complex" (i.e., $\epsilon_{c}$ ) are not these coefficients, but differences between them and the absorption coefficients of free uranyl ions, (i.e., $\epsilon_{c}-\epsilon_{u}$, cf. Equation (22)). This error has been corrected in Table 2.8. Furthermore, no indication can be found in the paper of Ghosh and Mitter as to whether their absorption coefficients were based on decadic or natural logarithms. Since in some later papers from Ghosh's laboratory, natural logarithms were specified, we presume that the same was true of the values of Ghosh and Mitter as well.

Table 2.7

$$
\begin{aligned}
& \text { COMPLEXING CONSTANTS OF URANYL IONS WITH ORGANIC ACIDS } \\
& \text { (AFTER GHOSH AND MTTER, 1928) } \\
& \mathrm{K}_{\mathrm{c}}(\mathrm{mole} / \ell)^{-1}=\frac{[\text { complex }]}{[\text { free uranyl }] \times[\text { free acid }]} ; \mathrm{D}=\frac{\left[\mathrm{H}^{+}\right]\left[\mathrm{A}^{-}\right]}{[\mathrm{AH}]}(\mathrm{mole} / \ell)^{-1}
\end{aligned}
$$

\begin{tabular}{|c|c|c|c|c|c|}
\hline Acid & Formula & $\mathrm{K}_{\mathrm{c}}(\mathrm{mole} / \ell)^{-1}$ & D $\times 10^{4}$ & $\sqrt{\mathrm{D}} \times 10^{2}$ & $\frac{\mathrm{K}_{\mathrm{c}}}{\sqrt{\mathrm{D}}}(\text { mole } / \ell)^{-1}$ \\
\hline Formic & $\mathrm{HCOOH}$ & 10 & 176 & 13 & 77 \\
\hline Acetic & $\mathrm{CH}_{3} \mathrm{COOH}$ & 6 & 17.5 & 4.2 & $143^{*}$ \\
\hline Propionic & $\mathrm{CH}_{3} \mathrm{CH}_{2} \mathrm{COOH}$ & 4 & 14 & 3.7 & 108 \\
\hline Oxalic & НОOС СOOH & 115 & 65,000 & 254 & 45 \\
\hline Malonic & $\mathrm{HOOC} \mathrm{CH}_{2} \mathrm{COOH}$ & 80 & 1,600 & 40 & 200 \\
\hline Succinic & $\mathrm{HOOC} \mathrm{CH}_{2} \mathrm{CH}_{2} \mathrm{COOH}$ & 50 & 66 & 8.2 & 610 \\
\hline Glycolic & $\mathrm{CH}_{2} \mathrm{OH} \mathrm{COOH}$ & 15 & - & - & - \\
\hline Lactic & $\mathrm{CH}_{3} \mathrm{CHOH} \mathrm{COOH}$ & 20 & - & - & - \\
\hline Tartaric $\dagger$ & HOOC CHOHCHOH COOH & 20 & 1,100 & 33 & 60 \\
\hline Mandelic & $\mathrm{C}_{6} \mathrm{H}_{5} \mathrm{CHOH} \mathrm{COOH}$ & 50 & - & - & - \\
\hline
\end{tabular}

*Ahrland (1951a) calculated $\mathrm{K}=240(\mathrm{~mole} / \ell)^{-1}$ for the first association constant of uranyl with acetate ions at $20^{\circ} \mathrm{C}, \eta=1.0$.

$\dagger_{\text {Rana Char }}(1942)$ calculated $K_{c} \cong 10$ from optical rotation measurements; $c$. Chap. 4 ,

The absorption coefficients given by Henri and Landau (Table 2.6) are generally lower than those given by Ghosh and Mitter; this may be due to the fact that the (unspecified concentrations of the acids used by Henri and Landau probably were not high enough to achieve complete complexing. (The values of Ghosh and Mitter were extrapolated to complete complexing, but extrapolation must have been unreliable because of disregard of changes in 
acid dissociation with the concentration of the acid in unbuffered solution.) The same criticism applies to the value in the last column given by Ghosh, Banerjee and Bhatta (1936) for the absorption coefficient of uranyl ions at $366 \mathrm{~m} \mu$ in $0.1 \mathrm{M}$ succinic acid.

Table 2.8

EFFECT OF COMPLEXING ON ABSORPTION SPECTRUM OF URANYL IONS IN AQUEOUS SOLUTION (AFTER GHOSH AND MITTER, 1928)

$$
\begin{aligned}
& \epsilon=\log _{10}\left(I_{0} / I\right) / c d \\
& c=\text { total concentration of uranium in mole/e } \\
& d=\text { light path in } \mathrm{cm}
\end{aligned}
$$

\begin{tabular}{|c|c|c|c|c|c|c|c|c|c|c|}
\hline \multirow{2}{*}{ Complex with } & \multicolumn{10}{|c|}{ Wavelength, $\mathrm{m} \mu$} \\
\hline & 250.7 & 254.5 & 260.0 & 272.2 & 277.0 & 296.1 & 327.4 & 336.4 & 343.5 & 366.0 \\
\hline None $^{*}$ & 304.3 & 260.9 & 239.1 & 130.4 & 108.7 & 65.2 & $(<43.5)$ & - & - & - \\
\hline Formate & 565.2 & 391.3 & 396.6 & - & 152.2 & 91.3 & - & - & - & - \\
\hline Acetate & - & 608.7 & 513.0 & 360.9 & 287.0 & 152.2 & - & - & - & - \\
\hline Propionate & 908.7 & 808.7 & 780.4 & - & 395.7 & 213.0 & - & - & - & - \\
\hline Oxalate & - & - & - & - & - & 534.8 & 239.1 & 117.4 & 63.0 & - \\
\hline Malonate & - & - & 934.8 & 521.7 & 408.7 & 165.2 & $(52.2)$ & - & - & - \\
\hline Succinate & 630.4 & 491.3 & 469.6 & - & 221.7 & 156.5 & $(78.3)$ & - & - & $7.39 \dagger$ \\
\hline Glycolate & - & 760.9 & 595.7 & 421.7 & 287.0 & 139.1 & $(56.5)$ & - & - & - \\
\hline Lactate & - & 782.6 & 673.9 & - & 369.6 & 195.7 & (91. 3) & - & - & - \\
\hline Tartrate & - & 956.5 & 752.2 & - & 360.9 & 256.5 & $(195.7)$ & $(130.4)$ & - & - \\
\hline Mandelate & - & - & - & 630.4 & 421.7 & 273.9 & $(130.4)$ & $(104.3)$ & $(65.2)$ & - \\
\hline
\end{tabular}

${ }^{*}$ Uranyl nitrate solution $5 \times 10^{-4} \mathrm{M}$ (cf. p. 16 about complexing with nitrate).

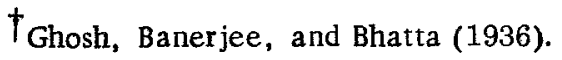

$\$$ See dat a of Ghosh, Naraganmuoti and Ray in Table 4.22; an $\in$ value of 15 is given there for $\lambda 436 \mathrm{~m} \mu$ 
32

The approximate proportionality between the values of $K_{c}$ and $\sqrt{D}$ in Table 2.7 supports the hypothesis that association occurs mainly between cations and anions (and not between cations and neutral acid molecules), and that the "constants" $K_{c}$ of the weaker acids measure their acid strength rather than the stability of their uranyl complexes.

Some figures for the effect of oxalic acid on the absorption spectrum of uranyl sulfate in the visible and the near ultraviolet (above $346 \mathrm{~m} \mu$ ) were given also by Pringsheim (1937). They are shown in Tables 2.9 and 2.10.

Table 2.9

EFFECT OF OXALATE ON AVERAGE ABSORPTION COEFFICIENTS OF URANYL SULFATE (AFTER PRINGSHEIM, 1937)

$\epsilon=\log _{10}\left(\mathrm{I}_{0} / \mathrm{I}\right) / \mathrm{cd} ; \mathrm{c}$ in mole $\mathrm{U} /$ liter.

\begin{tabular}{|c|c|c|c|c|c|}
\hline$\lambda(\mathrm{m} \mu)$ & 346.6 & 361.2 & 365.0 & 404.7 & 435.8 \\
\hline $\mathrm{UO}_{2} \mathrm{SO}_{4}(0.05 \mathrm{M})^{*}$ & 67 & 5.3 & 2.2 & 8.5 & 6 \\
same $+\mathrm{H}_{2} \mathrm{C}_{2} \mathrm{O}_{4}(0.005 \mathrm{M})$ & 200 & 20 & 11 & 10.5 & 7.5 \\
\hline
\end{tabular}

* According to p. 7, the se values correspond to a product of hydrolysis, rather than to free $\mathrm{UO}_{2}^{++}$ions.

Table 2.10

AVERAGE ABSORPTION COEFFICIENT OF URANYL IONS (0.02M) AT $365.0 \mathrm{~m} \mu$, AS FUNCTION OF CONCENTRATION OF ADDED OXALIC ACID (AFTER PRINGSHEIM, 1937) $\epsilon=\log _{10}\left(I_{0} / \mathrm{I}\right) / \mathrm{cd} ; \mathrm{c}$ in mole U/liter.

\begin{tabular}{|c|c|c|c|c|c|c|c|}
\hline$\frac{\left[\mathrm{H}_{2} \mathrm{C}_{2} \mathrm{O}_{4}\right]}{\left[\mathrm{UO}_{2} \mathrm{SO}_{4}\right]}$ & 0 & $1 / 16$ & $1 / 8$ & $1 / 4$ & $1 / 2$ & 1 & 2 \\
\hline$\epsilon(365.0 \mathrm{~m} \mu)$ & 2.2 & 2.9 & 3.7 & 4.9 & 7.2 & 11.1 & 12.4 \\
\hline
\end{tabular}

Table 2.10 shows that complexing is not complete even when more than one molecule of $\mathrm{H}_{2} \mathrm{C}_{2} \mathrm{O}_{4}(0.02 \mathrm{M})$ are present per molecule of uranyl sulfate; this indicates that the figures in Table 2.9 must be much lower than the true absorption coefficients of the uranyl oxalate complex. 


\section{3}

A systematic spectroscopic study of uranyl complexes in solution has been undertaken by Ahrland. His first paper (1949a) dealt with hydrolysis (cf. Section 1). He then (1949b) proceeded to study the complexing of $\mathrm{UO}_{2}^{++}$ions by monochloracetic acid, using the range below $\mathrm{pH} 3$, where hydrolysis is insignificant. Potentiometric measurements indicated that no polyuranyl complexes were formed; the spectroscopic data were interpreted correspondingly. The spectrum of a $10^{-2} \mathrm{M}$ solution of uranyl perchlorate showed, in the presence of $0.1 \mathrm{M}$ chloroacetate buffer, a general enhancement of absorption between 300 and $450 \mathrm{~m} \mu$. No exact spectral curves were determined, but absorption at $313 \mathrm{~m} \mu$ was studied as function of concentration. The result could be explained by assuming a sequence of three complexing steps (in the range from $[\mathrm{A}]=0.02 \mathrm{M}$ to $[\mathrm{A}]=0.4 \mathrm{M}$; the three complex dissociation constants (for $20^{\circ} \mathrm{C}$ and $\eta=1$ ) were calculated with the following results:

$$
\begin{array}{ll}
\mathrm{UO}_{2}^{++} \mathrm{A}^{-} & \mathrm{K}_{1}=24 \pm 3(\mathrm{~mole} / \ell)^{-1} \\
\mathrm{UO}_{2}^{++} \mathrm{A}^{--} & \mathrm{K}_{2}=150 \pm 40(\mathrm{~mole} / \ell)^{-2} \\
\mathrm{UO}_{2}^{++} \mathrm{A}_{3}^{---} & \mathrm{K}_{3}=350 \pm 150(\mathrm{~mole} / \ell)^{-3}
\end{array}
$$

Potentiometric measurements gave, for the same constants, the values 27.5 , 195 and 625 , respectively.

Ahrland (1949c) studied in the same way $\mathrm{UO}_{2}^{++}$complexes with thiocyanate ions. Figure $2.8 \mathrm{C}$ shows the effect of thiocyanate $(0.03$ to $0.16 \mathrm{M})$ on the absorption spectrum of $0.03 \mathrm{M}$ uranyl perchlorate. Again, no polynuclear complexes were found; dissociation constants of three monouranyl complexes were derived from extinction measurements at $366 \mathrm{~m} \mu$. The following values (for $20^{\circ} \mathrm{C}$ and $\eta=1$ ) were obtained:

$$
\begin{array}{ll}
\mathrm{UO}_{2}^{++} \mathrm{A}^{-} & \mathrm{K}_{1}=5.7(\mathrm{~mole} / \ell)^{-1} \\
\mathrm{UO}_{2}^{++} \mathrm{A}_{2}^{--} & \mathrm{K}_{2}=5.5(\mathrm{~mole} / \ell)^{-2} \\
\mathrm{UO}_{2}^{++} \mathrm{A}_{3}^{--} & \mathrm{K}_{3}=15(\mathrm{~mole} / \ell)^{-3}
\end{array}
$$

Ahrland (195la) then made a similar potentiometric and spectroscopic measurement on uranyl acetate. Figure 2.8D shows the spectra between $250 \mathrm{~m} \mu$ and $500 \mathrm{~m} \mu$ of uranyl solution in different acetate buffers. The wave length $260 \mathrm{~m} \mu$ was chosen for the calculation of acetate complexing constants, since at $\lambda>260 \mathrm{~m} \mu$, the hydrolysis effect on the spectrum became significant (as shown by the divergence of curves 2-6). By plotting the molar extinction coefficient as a function of acetate concentration, for three different uranyl concentrations, Figure 2.8E was obtained. For each value of $\epsilon$ (horizontal lines in the figure), the values of [acetate] are found to be linear functions of the corresponding values of [uranyl], indicating that only mononuclear complexes are formed. The following association constants were calculated: 


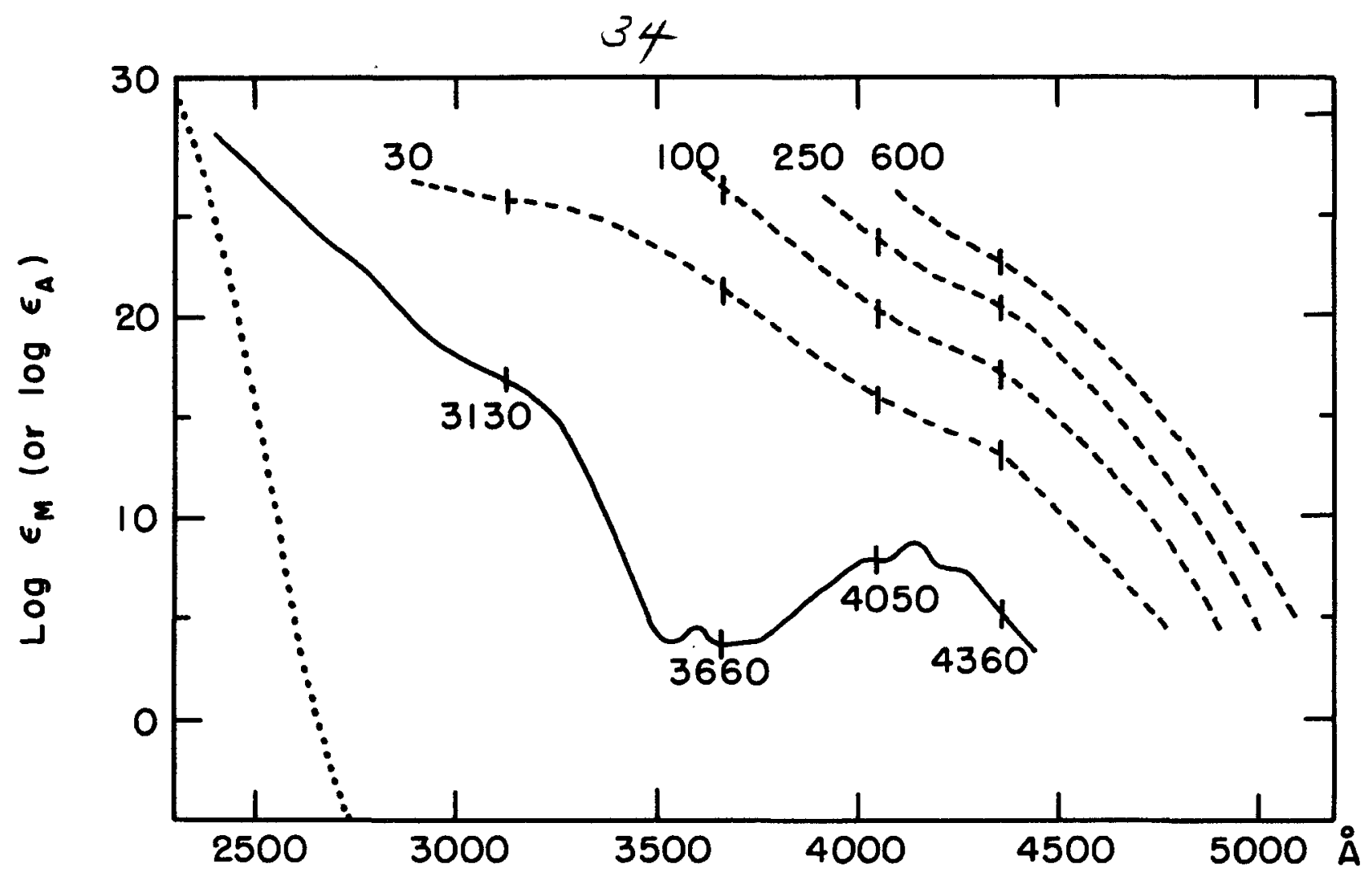

Figure 2.8C

MOLAR DECADIC EXTINCTION CURVES OF URANYL THIOCYANATE COMPLEXES

(AFTER AHRLAND, 1949c). SOLID LINE: URANYL IONS (FREE). DASHED LINES: $\left[\mathrm{UO}_{2}^{++}\right]_{0}=0.0331 \mathrm{M} ;[\text { THIOCYANATE }]_{0}=0.030,0.100,0.250$ AND $0.600 \mathrm{M}$, RESPECTIVELY. DOTTED LINE: THIOCYANATE ALONE, $\epsilon_{A}=\left(L O G I_{0} / 1\right) /[\text { THIOCYANATE }]_{0} D$. $\left[\mathrm{UO}_{2}^{++}\right]_{0}=$ TOTAL CONCENTRATION OF URANYL (COMPLEXED AND FREE).

$[\text { THIOCYANATE }]_{0}=$ TOTAL CONCENTRATION OF THIOCYANATE (IN $0.1 \mathrm{M} \mathrm{HC10}$, TO AVOID HYDROLYSIS OF URANYL; NO CORRECTION FOR INCOMPLETE DISSOCIATION OF THIOCYANIC ACID NEEDED; CONSTANT IONIC STRENGTH $\eta=1.0$ ADJUSTED BY $\mathrm{NaClO}_{4}$ ). 


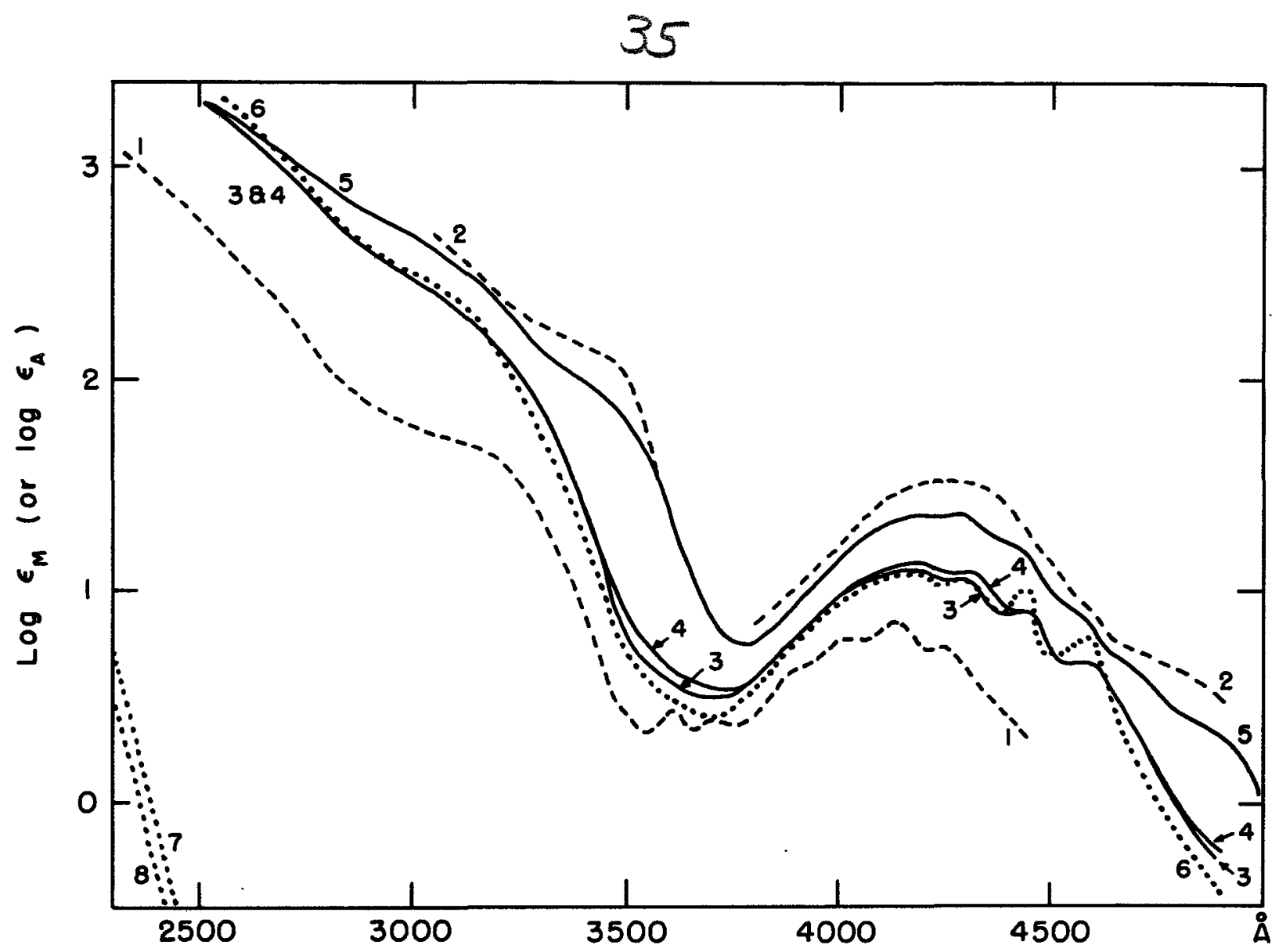

Figure 2.8D

MOLAR EXTINCTION CURVES OF URANYL ACETATE SOLUTIONS (AFTER AHRLAND, 1951a). CURVE 1: URANYL ION. CURVE 2: SAME, PARTIALLY HYDROLYSED $\left[\mathrm{UO}_{2}^{++}\right]_{0}=0.033 \mathrm{M}, \mathrm{pH}$ 4.1). CURVES 3, 4, 5: URANYL ACETATE COMPLEXES WITH $\left[\mathrm{UO}_{2}^{++}\right]_{0}=0.010 \mathrm{M},[\text { ACETATE }]_{0}=0.030 \mathrm{M}$, IN ACETIC ACID-ACETATE BUFFERS 5:1, 2:1, AND 0.5:1, RESPECTIVELY. CURVE 6: SAME, WITH $\left[\mathrm{UO}_{2}^{++}\right]_{0}=0.010 \mathrm{M},[\text { ACETATE }]_{0}=0.060 \mathrm{M}$, IN ACETIC ACID-ACETATE BUFFER $2: 1$. CURVES 7, 8: ACETIC ACID-ACETATE BUFFERS 5:1 AND 0.5:1, RESPECTIVELY. $\left[\mathrm{UO}_{2}^{++}\right]_{0}=$ TOTAL CONCENTRATION OF FREE AND COMPLEXED URANYL; [ACETATE $]_{0}=$ TOTAL CONCENTRATION OF ACETATE USED (A SMALL CORRECTION MUST BE MADE FOR THE EFFECT OF ACETIC ACID ON THE CONCENTRATION OF FREE ACETATE IONS). COMPLEXING OF URANYL WITH ACETATE STRONG ENOUGH TO PREVENT HYDROLYSIS IN ABOVE BUFFERS. IONIC STRENGTH $\eta=1.0$ ADJUSTED BY $\mathrm{NaClO}_{4}$. 


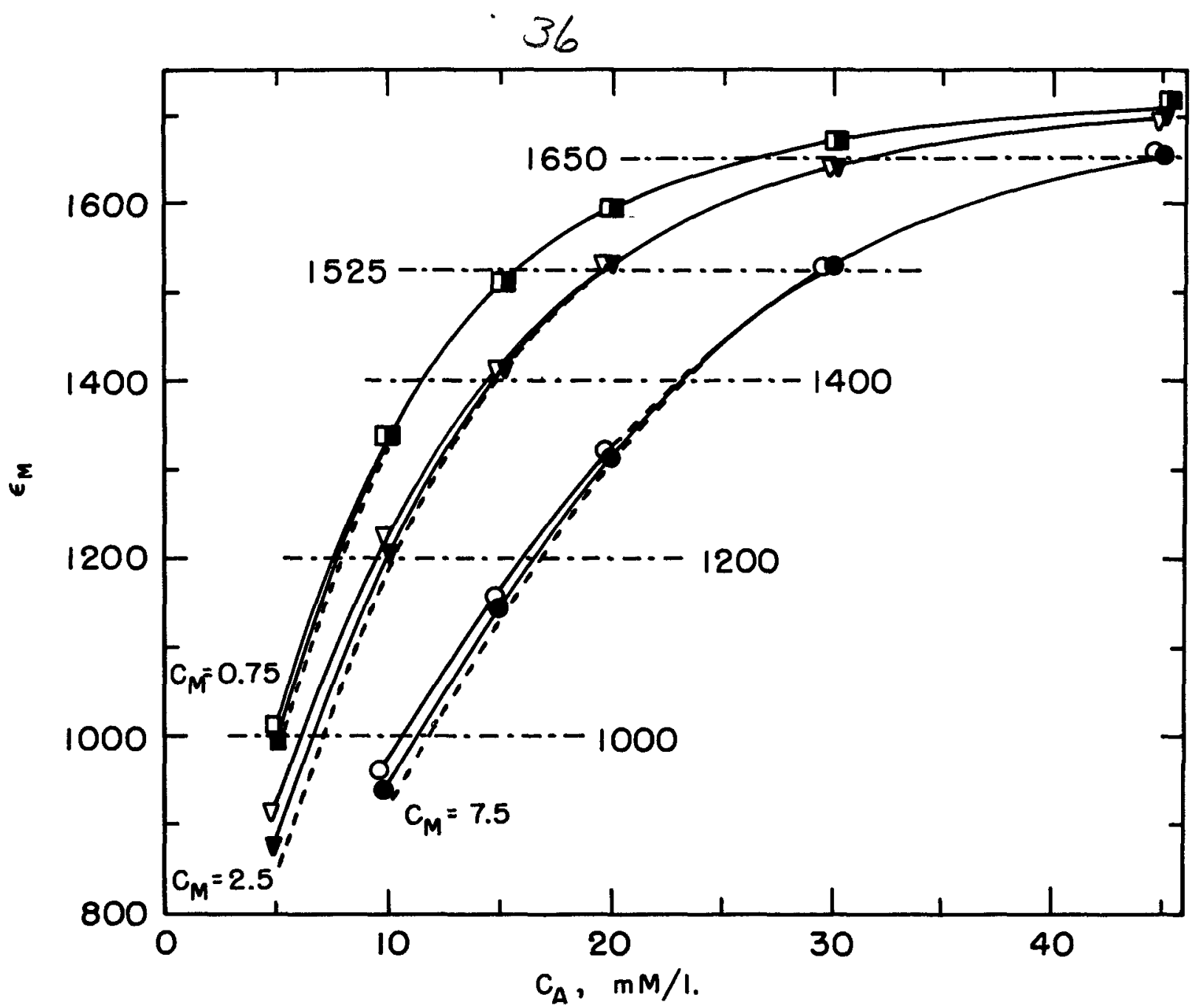

Figure $2.8 \mathrm{E}$

MOLAR DECADIC EXTINCTION COEFFICIENTS OF URANYL ACETATE COMPLEX SOLUTIONS AS FUNCTION OF TOTAL CONCENTRATION OF ACETATE $C_{A}$ (FREE + COMPLEXED WITH URANYL). $\square . \square:\left[\mathrm{UO}_{2}^{++}\right]_{0}=0.00075 \mathrm{M}$;

$\nabla . \nabla:\left[\mathrm{UO}_{2}^{++}\right]_{0}=0.0025 \mathrm{M} ; O . \mathrm{O}:\left[\mathrm{UO}_{2}^{++}\right]_{0}=0.0075 \mathrm{M}$. OPEN SIGNS: [ACETIC ACID]: [ACETATE] = 5; FULL SIGNS: [ACETIC ACID]: [ACETATE] $=2$. DASHED LINES EXTRAPOLATED TO $\left[\mathrm{H}^{+}\right]=\infty$ (NO HYDROLYSIS). THE POINTS IN WHICH A HORIZONTAL $\epsilon_{M}=$ CONST. CROSSES THE SEVERAL CURVES CORRESPOND TO THE SAME CONCENTRATION OF FREE ANIONS. 


$$
\begin{aligned}
& \mathrm{K}_{1}=240(\operatorname{mole} / \ell)^{-1} \\
& \mathrm{~K}_{2}=2.3 \times 10^{4}(\mathrm{~mole} / \ell)^{-2} \\
& \mathrm{~K}_{3}=2.2 \times 10^{6}(\mathrm{~mole} / \ell)^{-3}
\end{aligned}
$$

for $20^{\circ} \mathrm{C}$ and ionic strength 1.0 .

Table 2.10A summarizes the complexing constants derived by Ahrland $(1949,1951)$ for mononuclear uranyl ions. with several inorganic and organic ions.

Table 2.10A

SPECTROSCOPICALLY DETERMINED EQUILIBRIUM CONSTANTS OF REACTIONS UO ${ }_{2}^{++}+\mathrm{nA}^{-}=\mathrm{UO}_{2}^{+} \mathrm{A}_{n}^{-\mathrm{n}}$ AFTER AHRLAND $(1949,1951) .20^{\circ} \mathrm{C}$; ionic strength 1.0 .

\begin{tabular}{|l|l|l|l|}
\hline \multicolumn{1}{|c|}{$\mathrm{A}^{-}$} & \multicolumn{1}{|c|}{$\begin{array}{c}\mathrm{n}=1 \\
(\mathrm{~mole} / \ell)^{-1}\end{array}$} & \multicolumn{1}{c|}{$\begin{array}{c}\mathrm{n}=2 \\
(\mathrm{~mole} / \ell)^{-2}\end{array}$} & \multicolumn{1}{c|}{$\begin{array}{c}\mathrm{n}=3 \\
(\mathrm{~mole} / \ell)^{-3}\end{array}$} \\
\hline $\mathrm{OH}^{-}$ & $2 \times 10^{9 *}$ & & \\
$\mathrm{Cl}^{-}$ & $0.5( \pm 0.3)$ & & \\
$\mathrm{SO}_{4}^{-}$ & $56( \pm 6)$ & $450( \pm 50)$ & \\
$\mathrm{CH}_{3} \mathrm{COO}^{-}$ & $240( \pm 10)$ & $2.3 \times 10^{4}( \pm 0.2)$ & $2.2 \times 10^{6}( \pm 0.3)$ \\
$\mathrm{CH}_{2} \mathrm{ClCOO}^{-}$ & $24( \pm 3)$ & $150( \pm 40)$ & $350( \pm 150)$ \\
$\mathrm{CNS}^{-}$ & $5.7( \pm 0.3)$ & $5.5( \pm 1)$ & $15( \pm 5)$ \\
\hline
\end{tabular}

*Ahrland gives $2 \times 10^{-5}$ mole/ $/ \ell$ for $\left[\mathrm{UO}_{2}^{++} \mathrm{OH}^{-}\right]\left[\mathrm{H}^{+}\right] /\left[\mathrm{UO}_{2}^{++}\right]$(cf. p. 13); assuming $\left[\mathrm{H}^{+}\right]\left[\mathrm{OH}^{-}\right] \simeq 10^{14}$, we calculate $\left[\mathrm{UO}_{2}^{++} \mathrm{OH}^{-}\right] /\left[\mathrm{UO}_{2}^{++}\right]\left[\mathrm{OH}^{-}\right]$ $=2 \times 10^{9}(\text { mole } / \ell)^{-1}$.

Foley and Anderson (1949) observed the effect of sulfosalicylic acid on the spectrum of an aqueous solution of uranyl acetate. Figure 2.9 shows the absorption curves of a $5 \times 10^{-3} \mathrm{M}$ solution of $\mathrm{UO}_{2} \mathrm{Ac}_{2}$ ( $\mathrm{pH} 4.5$ ) (curve I) and of a $7.5 \times 10^{-4} \mathrm{M}$ solution of $\mathrm{UO}_{2} \mathrm{Ac}_{2}$ to which $4.25 \times 10^{-3} \mathrm{M}$ sulfosalicylic acid has been added ( $\mathrm{pH} 4.65$ )(curve II). Although the added acid does not absorb in the visible, and the concentration of $\mathrm{UO}_{2}^{++}$is lower by a factor of 6.7, absorption curve II lies much higher than curve I. The acetate curve probably corresponds to a solution containing hydrolyzed uranyl ions $\left(\left[\left(\mathrm{UO}_{2}\right)_{3} \mathrm{O}_{2}\right]^{++}\right.$according to Sutton's Figure 2.3) and uranyl acetate complexes. According to Tables 2.6 and 2.8 , the uranyl acetate complexes absorb strongly in the far ultraviolet; but their formation does not affect significantly 


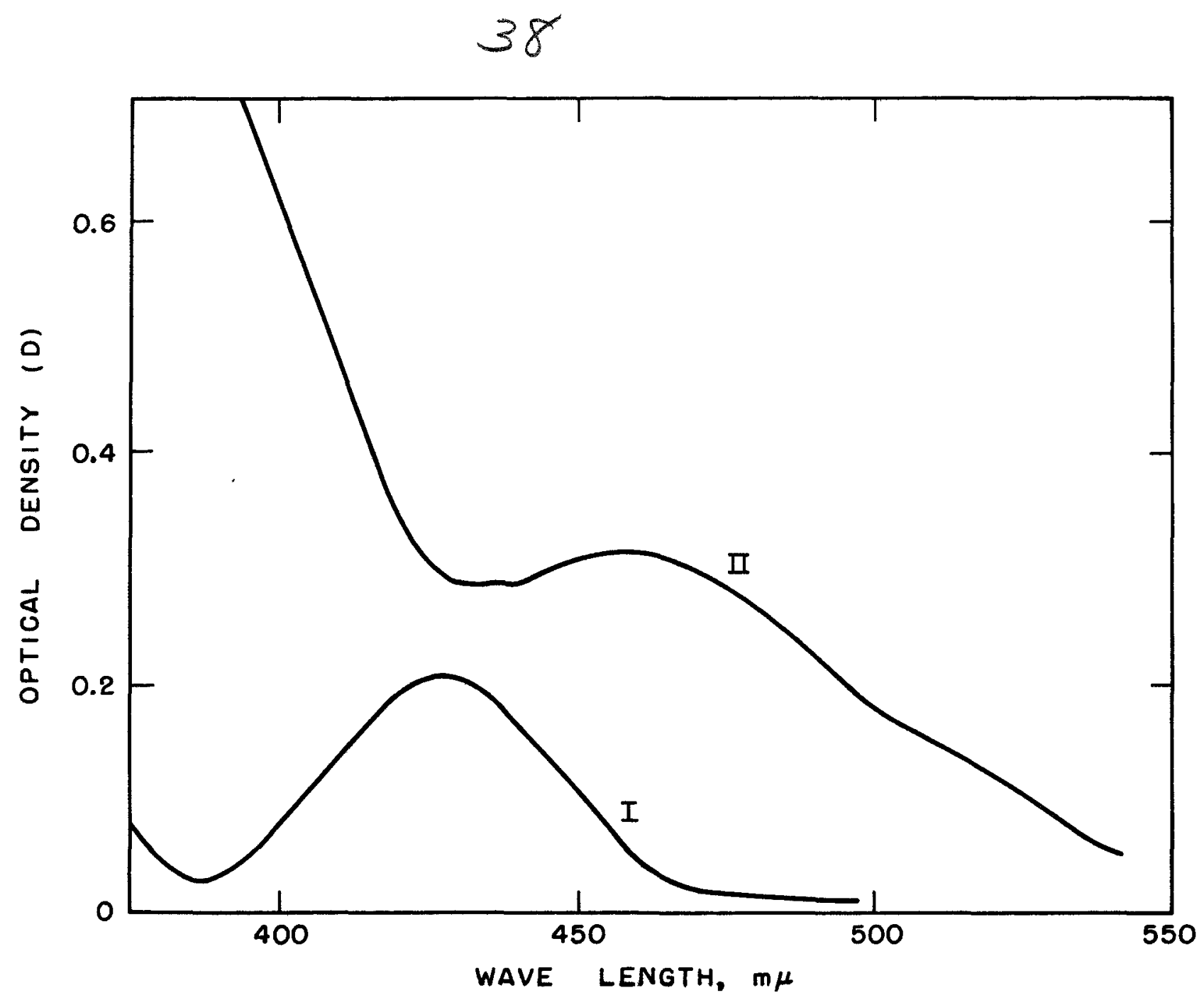

Figure 2.9

EFFECT OF SULFOSALICYLIC ACID ON ABSORPTION SPECTRUM OF URANYL IONS (AFTER FOLEY AND ANDERSON, 1949) CURVE $1: 5 \times 10^{-3} \mathrm{MUO}_{2} \mathrm{Ac}_{2}$. CURVE II: $7.5 \times 10^{-4} \mathrm{MUO}_{2} \mathrm{Ac}_{2}+4.25 \times 10^{-3} \mathrm{M}$ SULFOSALICYLIC ACID. 
the visible and near ultraviolet spectrum, which remains similar to that of nitrate. The sulfosalicylate complex, on the other hand, absorbs strongly in the visible and near ultraviolet. Foley and Anderson noted that addition of increasing amounts of acetate buffer caused absorption in the visible region to become weaker, indicating competition of acetate with sulfosalicylate for uranyl ions.

By plotting the difference between the optical density, at selected wave lengths, of the mixture and of an equal amount of uranyl salt without sulfosalicylic acid, as a function of the ratio $x=\left[\mathrm{UOS}_{2}^{+}\right] /\left(\left[\mathrm{UO}_{2}^{+}\right]+[\mathrm{SSA}]\right)$, Foley and Anderson obtained, for $\lambda=400,420,440$ and $460 \mathrm{~m} \mu$, symmetrical curves with peaks at $x=0.5$. As first pointed out by Job, this is a proof of formation of a $1: 1$ complex. The same result was obtained at $\mathrm{pH} 4.6,5.1$ and 6.1 . The optical density was highest at pH 4.5-4.7, and declined at both lower and higher $\mathrm{pH}$ values. The decline at low $\mathrm{pH}$ values was considered as indicating that the complex formation occurred with the divalent anion of the sulfosalicylic acid $(\mathrm{pK}=2.86)$; the decline at high $\mathrm{pH}$ values was ascribed to hydrolysis.

The extinction coefficients of the complex were determined by using a solution containing a 9:1 excess of the complexing anions; they were $\epsilon=403$ at $440 \mathrm{~m} \mu$ and $\epsilon=432$ at $460 \mathrm{~m} \mu$. Using these values, the concentration of the complex was calculated in different mixtures, and thence the dissociation constant was derived:

$$
\mathrm{K}=\frac{\left[\mathrm{UO}_{2}^{++}\right][\mathrm{R}]}{\left[\mathrm{UO}_{2}^{++} \mathrm{R}\right]}=(1.3 \pm 0.8) \times 10^{-4}(\mathrm{~mole} / \ell)^{-1}
$$

corresponding to a complexing constant of between 5,000 and 20,000. An improved method of calculation, using solution pairs of constant ionic strength, with the same complex concentration, but different ratios of the components, led to a more precise value:

$$
\mathrm{K}=(1.93 \pm 0.08) \times 10^{-4}\left(25^{\circ} \mathrm{C}\right)
$$

or $1 / K \simeq 5200$. This corresponds to a free energy of association

$$
\Delta F=-5.06 \mathrm{kcal}\left(25^{\circ} \mathrm{C}\right)
$$

Raising the temperature increases the complexing, but the increase is slight, indicating a small negative heat of formation.

Concentration [R] in Equation (23) refers to total acid, which at the $\mathrm{pH}$ of maximum color depth is completely dissociated into $\mathrm{R}^{--}$and $2 \mathrm{H}^{+}$. $\mathrm{A}$ complex of a divalent anion and a divalent cation ( $\mathrm{UO}_{2}^{++}$) is neutral as a whole, but Foley and Anderson suggested that the uranyl sulfosalicylate complex is a "zwitterion,"," $+\mathrm{UO}_{2} \mathrm{R}^{-}$. 


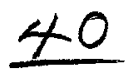

Foley and Anderson found that addition of $0.18 \mathrm{M}$ acetate to $0.002 \mathrm{M}$ sulfosalicylate reduces the optical density at $460 \mathrm{~m} \mu$ from 0.643 to 0.242 ; this indicates a ratio of association constants of the order of $10^{2}$, i.e., an acetate complexing constant of the order of 50. This can be compared with the value of 240 (mole/ $/ \ell)^{-1}$ derived by Ahrland (for $20^{\circ} \mathrm{C}$ and $\eta=1.0$ ), and also with the value of $\mathrm{K}_{\mathrm{C}} / \sqrt{\mathrm{D}}$ given in the last column of Table 2.7 . If it is assumed that the latter corresponds to an average acetic acid concentration of $\overline{\mathrm{A}}_{0} \simeq 0.1 \mathrm{M}$ (it was calculated from measurements between 0.005 and $1 \mathrm{M})$, the corresponding value of $K$ is

$$
K=\frac{K_{c} \sqrt{A_{0}}}{\sqrt{D}} \simeq 40(\text { mole } / \ell)^{-1}
$$

Since complexing of uranyl ions with organic acids is of great importance for the behavior of uranium in the living organism, it has been also studied by toxicologists. Electrochemical methods (polarography, transference, etc.) have been used by them, and only a few spectroscopic observations have been made. The results obtained up to 1947 were summarized by Dounce et al. (1949). One important general result of electrochemical studies is that they indicated, in all systems studied, the formation of higher complexes in addition to the $1: 1$ complexes whose existence appeared sufficient to explain the above-described spectroscopic results of other investigators. For example, in acetate buffers ( $\mathrm{NaAc}+\mathrm{HAc}$ ) a neutral complex, probably $\mathrm{UO}_{2}^{++} \mathrm{Ac}_{2}^{-}$, was indicated at $\left[\mathrm{Ac}^{-}\right]>0.025 \mathrm{M}$ by trans ference measurements at $20^{\circ} \mathrm{C}$, and at $\left[\mathrm{Ac}^{-}\right]>0.05 \mathrm{M}$ by polarographic measurements at $25^{\circ} \mathrm{C}$. An anionic uranyl acetate complex, probably $\mathrm{UO}_{2}^{++} \mathrm{Ac}_{3}^{---}$, also was observed in transference experiments. Its relative concentration was independent of the concentration of neutral acetic acid molecules and only dependent on that of the Ac-ions, as expected for a complex in whose formation only acetate ions take part.

Absorption changes observed in $0.2 \mathrm{M}$ acetate buffers with varying $\mathrm{pH}$, described in the same review, probably refer to hydrolysis rather than formation of uranyl acetate complexes (as assumed by the review). They have been therefore described in Section 1 of this chapter.

Polarographic studies have been continued by the Rochester toxicological group with other organic acids, such as pyruvic, malic, and particularly citric, by Neuman et al. [Neuman and Havill (1948), Rodgers and Neuman (1948), and Neuman, Havill and Feldman (1949)]. They led to the conclusion that dicarboxylic acids generally have a stronger tendency for association with uranyl ions than acetic acid, even when - as in the case of succinic acid - their dissociation constant is not higher than that of acetic acid. It was surmised that complexing with dibasic acids involves formation of 5-,6-or 7-membered rings with both carboxyls. In fact mixing uranyl nitrate ( $\mathrm{pH} \mathrm{2.8)}$ with oxalic acid ( $\mathrm{pH} 1.6$ ) lowered the $\mathrm{pH}$ to 1.3 , indicating that uranyl ions displaced a second proton from the monobasic oxalic acid anion. 
A further complication of the complexing mechanism was found in these studies: it was deduced that the 1:1 uranyl citrate complex forms a rather stable dimer. The formation of the dimer was described by Neuman et al. (1949) in the following way:

$$
\begin{aligned}
& \mathrm{UO}_{2}^{++}+\mathrm{H}_{2} \mathrm{Cit}^{-} \longrightarrow \mathrm{UO}_{2}^{+} \mathrm{HCit}^{2}+\mathrm{H}^{+} \\
& 2\left\{\mathrm{UO}_{2}^{++} \mathrm{HCit}^{=}\right\} \longrightarrow\left\{\left(\mathrm{UO}_{2}^{++}\right)_{2} \mathrm{H}^{+}\left(\mathrm{Cit}^{\equiv}\right)_{2}\right\}+\mathrm{H}^{+}(=\text {dimer } \\
&
\end{aligned}
$$

giving for the dissociation constant the expression

$$
\mathrm{K}_{\mathrm{d}}=\frac{\left[\mathrm{UO}_{2}^{++}\right]\left[\mathrm{H}_{2} \mathrm{Cit}^{-}\right]}{\left[\mathrm{H}^{+}\right]^{3 / 2}\left[\text { dimer }^{-}\right]^{1 / 2}}
$$

A value of $0.18 \pm 0.08$ was calculated for $K_{d}$ at $p H 2.9-3.6$ and a total uranyl concentration of $5 \times 10^{-4} \mathrm{M}$.

The uranyl citrate system was further studied spectroscopically by Feldman, Neuman and Havill (1949). Figure 2.10A represents the optical density of uranyl salt solutions with and without added citric acid, in the alkaline region ( $\mathrm{pH} 7.5$ ) and in the acid region ( $\mathrm{pH} 3.75)$. The steep change of absorption (at $320 \mathrm{~m} \mu$ ) as a function of $\mathrm{pH}$ in the regions $<3$ and 5-7 (Figure 2.10B) indicates successive formation of two complexes; the second one is stable up to $\mathrm{pH} 11$ (while non-complexed uranyl nitrate solution of the same concentration precipitates above $\mathrm{pH} 4.5$ ).

The complex that is stable at $\mathrm{pH} 3.85$ has the composition $1 \mathrm{UO}_{2}^{+}$: 1 citrate, as shown by the plot of absorption coefficients (at 320,330 or $350 \mathrm{~m} \mu)$ as function of $\left[\mathrm{UO}_{2}^{++}\right] /\left\{\left[\mathrm{UO}_{2}^{++}\right]+[\right.$citrate $\left.]\right\}$(Figure 2.10C). The authors assume, on the basis of previously described electrochemical results, that this complex is present mainly as a dimer, and calculated its dissociation constant according to Equation (24). The $\mathrm{K}_{\mathrm{d}}$ values obtained were 0.04 for $1 \times 10^{-4} \mathrm{M}$ uranyl solution $(\mathrm{pH} 3.16-3.69)$ and 0.065 for $5 \times 10^{-4} \mathrm{M}$ solution ( $\mathrm{pH} 3.03$ ). The agreement with the previously given potentiometric value $(K=0.18)$ is only in the order of magnitude; it is suggested that the spectroscopic values are more reliable.

The nature of the more strongly colored complex present at $\mathrm{pH} 7.5$ has not been clarified, but it seems to involve a uranyl:citrate ratio $>1$, perhaps 1.5 .

The absorption curves of aqueous solutions of a number of complex uranyl salts (mainly of the aldimine series) have been measured by von Kiss and co-workers in their extensive study of the spectra of such complexes [see von Kiss and Nyiri (1942b), and von Kiss, Csokan and Nyiri (1942a)].

Spectra of uranyl salts complexed with organic bases (or their salts) in organic solvents will be discussed in the next section. Some partaqueous systems, such as the system uranyl nitrate and tetrabutyl ammonium nitrate and concentrated nitric acid, will be included in this discussion. 


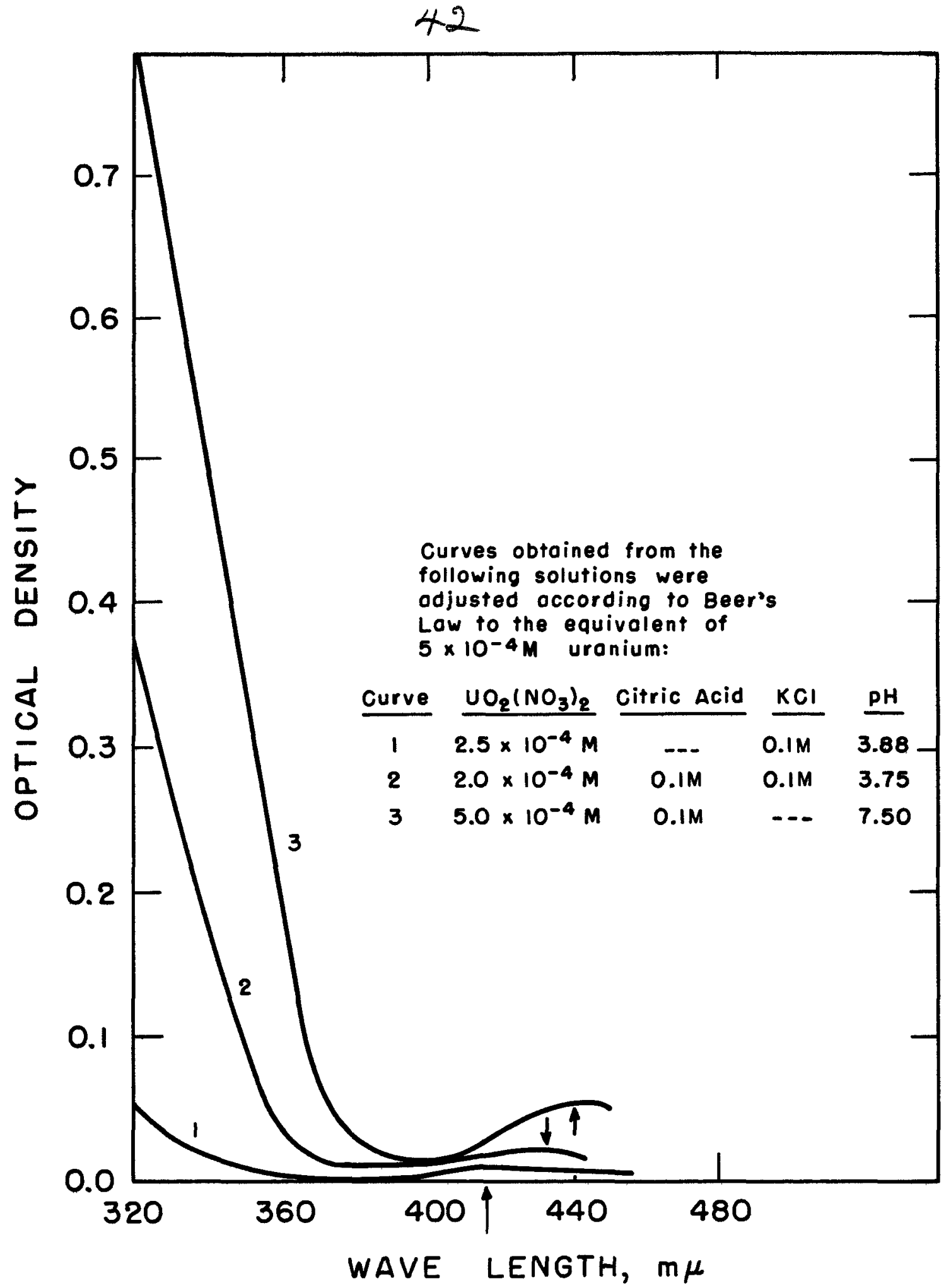

FIG. 2.IOA-ABSORPTION SPECTRA OF URANYL CHLORIDE AND URANYL CITRATE. 
43

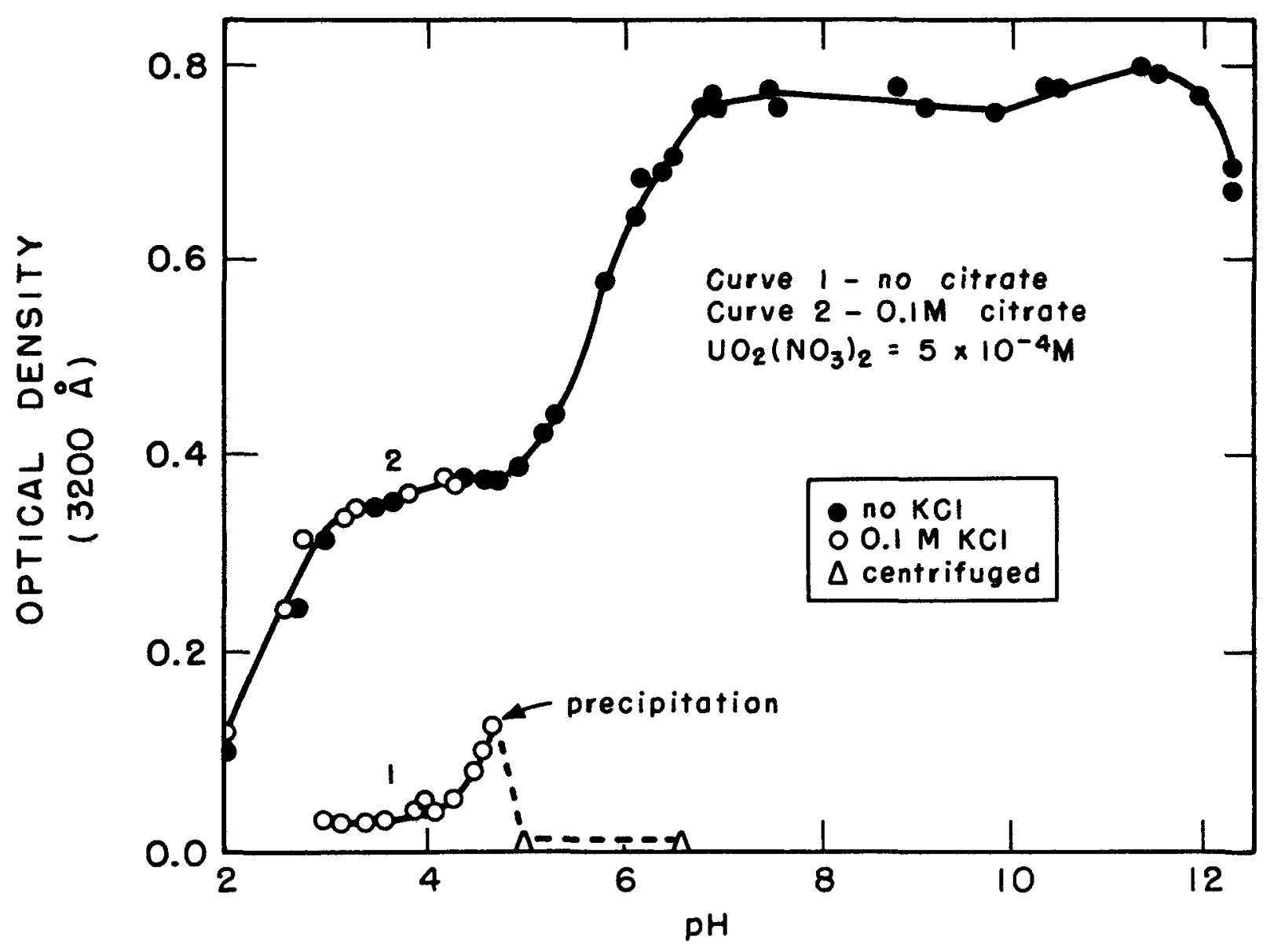

FIG. 2.1OB - THE EFFECT OF PH ON ABSORPTION OF URANYL SOLUTIONS. 


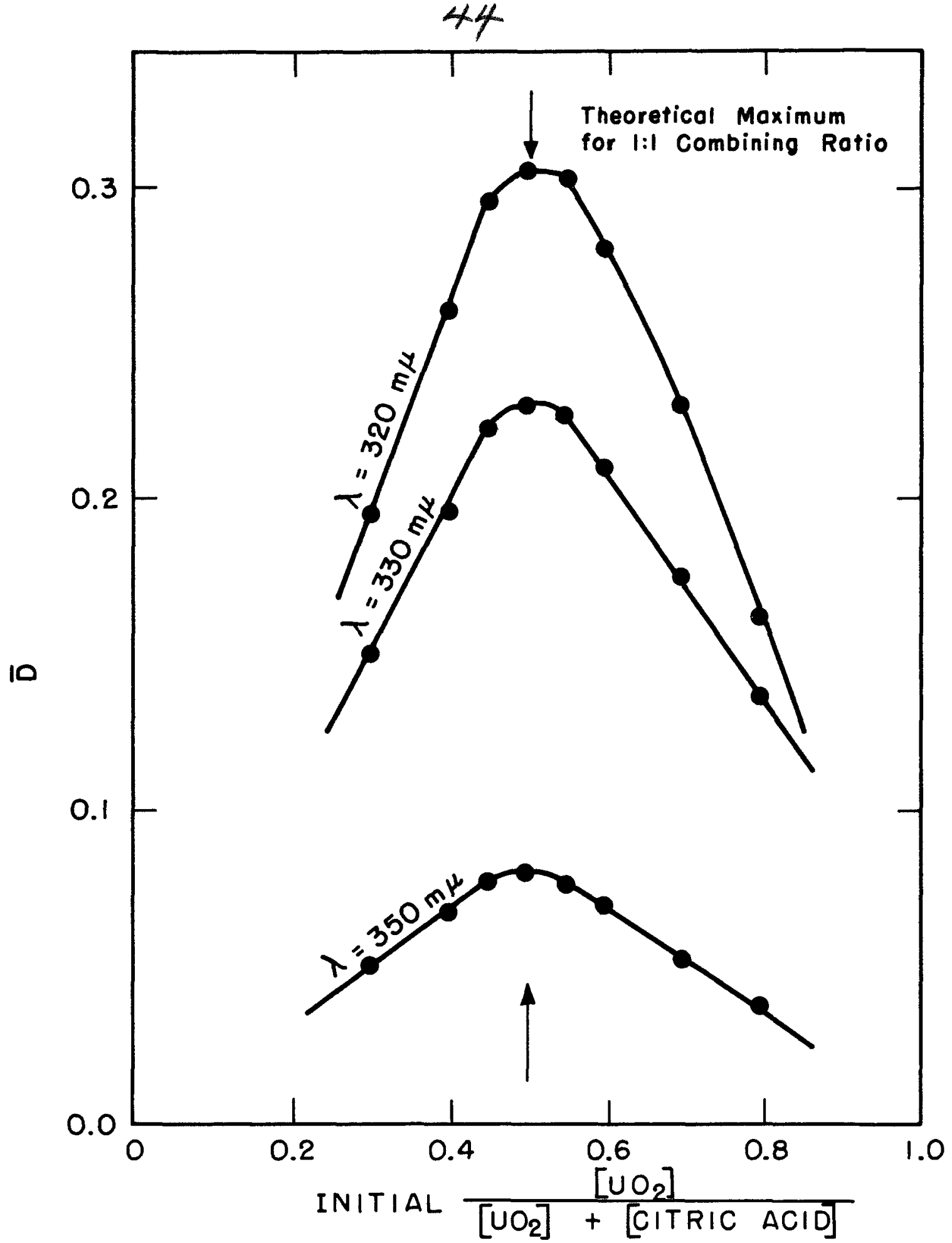

FIG. 2.1OC-APPLICATION OF JOB'S METHOD OF CONTINUOUS VARIATIONS TO THE STUDY OF THE URANYL CITRATE COMPLEX AT PH $3.85 \pm 0.03$. 


\section{5 \\ 3. ABSORPTION SPECTRA OF URANYL COMPOUNDS IN ORGANIC SOLVENTS}

Most comparisons of uranyl salt spectra in different solvents suffer from the lack of information concerning the nature of molecular species neutral or ionized - present in solution.

The first extensive comparisons of this type were made by Deussen (1898). He measured the positions of ten uranyl bands (486-369 $\mathrm{m} \mu)$ in water, methanol, ethanol, acetone, glycerol, amylol, acetic ester and ether. Addition of $50 \% \mathrm{C}_{2} \mathrm{H}_{5} \mathrm{OH}$ to water was found to shift all bands towards the red, but the direction of the shift was reversed in $80 \%$ and $100 \%$ ethanol. Addition of glycerol to water caused a shift of all bands towards the red; this shift increased with the amount of glycerol.

Jones and Strong (1910a) photographed the absorption spectra and estimated the positions of the band peaks of uranyl chloride and uranyl nitrate, in water, methanol, ethanol, glycerol, acetone, and in binary mixtures of these solvents and also of uranyl acetate in water and in methanol.

They noted that the absorption bands were considerably stronger in methanol than in water; the band peaks were sharper and were generally shifted towards the red. Beer's law was found to hold between $0.06 \mathrm{~N}$ and $0.25 \mathrm{~N}$ solutions of uranyl chloride in ethanol. Addition of calcium chloride had almost no effect on the absorption spectrum of uranyl chloride in methanol (in contradistinction to the behaviour of the same compound in aqueous solution).

A summary of the band positions of uranyl chloride in different solvents, including those above-mentioned, and also some investigated in a subsequent study by Jones and Strong (1912), is given in Table 2.11 .

The same authors observed the effect of temperature on the absorption spectra of uranyl chloride in acetone $\left(22-195^{\circ}\right)$, of uranyl nitrate in propanol $\left(20^{\circ}-145^{\circ} \mathrm{C}\right)$, and of both these salts in isobutanol $\left(20-115^{\circ} \mathrm{C}\right)$ and methyl sulfate.

Von Kurelec (1927) made a comparison of the positions of the four lowest frequency bands of uranyl nitrate in 44 organic solvents: 13 aliphatic alcohols and glycols, 7 aliphatic aldehydes, 8 aliphatic acids, 9 esters of such acids, 4 nitriles, ether, acetone, and citronellal.

In all solvents, ionizing and non-ionizing, the position of the absorption bands of uranyl nitrate was approximately the same, For example, the center of the first band lay in aqueous solutions between $483 \mathrm{~m} \mu$ (conc. $\mathrm{HNO}_{3}$ ) and $493 \mathrm{~m} \mu$ (conc. $\mathrm{HCl}$ ) and in organic solvents between $483.4 \mathrm{~m} \mu$ (glacial acetic acid) and $490.4 \mathrm{~m} \mu$ (glycol). Similarly, the center of the second band lay between 468 and $478 \mathrm{~m} \mu$ in aqueous solutions, and between 466.6 and $472.9 \mathrm{~m} \mu$ in organic solutions. 
46

Table 2.11

\section{ABSORPTION BANDS OF URANYL CHLORIDE \\ IN DIFFERENT SOLVENTS}

(after Jones and Strong 1910a, 1912)

\begin{tabular}{|l|c|c|c|c|c|c|c|}
\hline \multirow{2}{*}{\multicolumn{1}{c|}{ Solvent }} & \multicolumn{7}{c|}{ Band Centers (mu) } \\
\cline { 2 - 8 } & 1 & 2 & 3 & 4 & 5 & 6 & 7 \\
\hline $\mathrm{H}_{2} \mathrm{O}$ & 492 & 474 & 456 & 446 & 431.5 & 417 & 402.5 \\
$\mathrm{CH}_{3} \mathrm{OH}$ & 493 & 476 & 459 & 446.5 & 434.5 & 422 & 409 \\
$\mathrm{C}_{2} \mathrm{H}_{5} \mathrm{OH}$ & 490 & 475 & 458 & 440 & - & 425 & 410 \\
$\mathrm{C}_{3} \mathrm{H}_{7} \mathrm{OH}$ & 491 & 475 & 458 & 458 & 446.0 & 423 & 410 \\
$\mathrm{i}-\mathrm{C}_{3} \mathrm{H}_{7} \mathrm{OH}$ & - & 475 & 456 & 436 & - & 425 & 410 \\
$\mathrm{C}_{4} \mathrm{H}_{9} \mathrm{OH}$ & 497 & - & 475 & 456 & 439 & 424 & 410 \\
$\mathrm{i}-\mathrm{C}_{4} \mathrm{H}_{9} \mathrm{OH}$ & 490 & - & 472 & 456 & 440 & - & - \\
$\left(\mathrm{C}_{2} \mathrm{H}_{5}\right)_{2} \mathrm{O}$ & - & - & 463 & 444 & 430 & 416 & 404 \\
$\mathrm{CH}_{3} \mathrm{OOCH}$ & 492 & 479 & 462 & 444 & 428 & 416 & 403 \\
$\mathrm{Glycerol}_{3}$ & 505 & 472 & 454 & 440 & 426 & 414 & 402.5 \\
F ormamide & 484 & - & 465 & 445 & - & - & - \\
\hline
\end{tabular}

Within a homologous series (e.g., the series of saturated straight chain alcohols, from $\mathrm{CH}_{3} \mathrm{OH}$ to $\mathrm{C}_{8} \mathrm{H}_{17} \mathrm{OH}$ ), a "red shift" could be observed with increased index of refraction of the solvent (cf. Table 2.12). (No similar regularity is noticeable in Table 2.11.)

In mixed organic solvents, early observations indicated preferential association of uranyl salts (or their ions) with one of the components. Thus, Hartley (1903) concluded from spectroscopic evidence that when hydrated uranyl nitrate is dissolved in ether the spectrum remains that characteristic of uranyl ions in water.

Jones and Strong (1910a) noted that addition of as little as $8 \%$ water to a uranyl chloride solution in methanol caused the uranyl bands to shift appreciably towards their position in aqueous solution. Similarly, addition of $10 \%$ glycerol to methanol caused the spectrum of uranyl chloride to. assume the character of that in pure glycerol. 


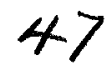

Table 2.12

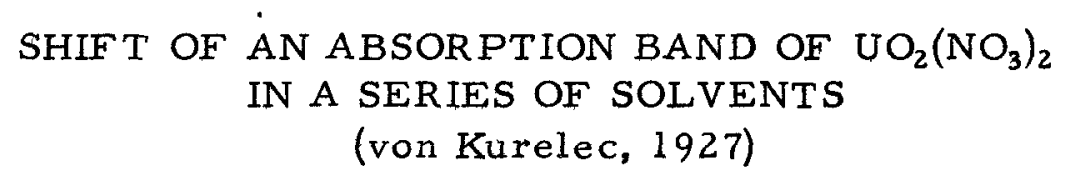

\begin{tabular}{|l|c|c|}
\hline Solvent & $\mathrm{m} \mu$ & $\eta$ \\
\hline $\mathrm{CH}_{3} \mathrm{OH}$ & 465.0 & 1.3326 \\
$\mathrm{C}_{2} \mathrm{H}_{5} \mathrm{OH}$ & 465.8 & 1.3614 \\
$\mathrm{C}_{3} \mathrm{H}_{7}^{-} \mathrm{OH}$ & 466.3 & 1.3859 \\
$\mathrm{C}_{4} \mathrm{H}_{9} \mathrm{OH}$ & 467.9 & 1.3991 \\
$\mathrm{C}_{5} \mathrm{H}_{11} \mathrm{OH}$ & 467.2 & 1.4078 \\
$\mathrm{C}_{8}^{5} \mathrm{H}_{17} \mathrm{OH}$ & 467.4 & 1.4314 \\
\hline
\end{tabular}

Jones and Strong (1912) and Jones (1913a) asserted that the broadened and shifted bands observed in uranyl salt solutions in methanol upon addition of water can be interpreted as the result of mutual superposition of "methanolate bands" and "hydrate bands," a conclusion which they used as argument supporting the solvate theory of solutions. Ta test this theory was the main motivation of the long series of studies devoted to absorption spectra of inorganic salts by Jones and co-workers, and summarized in Jones and Strong's monographs in 1910 and 1911. (The most convincing examples of the coexistence of bands characteristic of individual solvents in a mixed solvent were found by Jones in solutions of U(IV) salts, such as $\mathrm{UBr}_{4}$. )

Müller (1940) observed that the ultraviolet absorption edge of uranyl nitrate is shifted towards the longer waves, and the absorption appears stronger when ether is substituted for water as solvent. The effect is stronger the more dilute the uranyl solutions.

Mathieson (1949) studied the absorption spectra of uranyl nitrate in two ketones: acetone and methyl ethyl ketone, and, for comparison, in diethyl ether and water. He found, in ketonic solutions, a sharp enhancement of the long-wave absorption peaks, and a general increase in absorption intensity above $330 \mathrm{~m} \mu_{0}$ He attributed these spectral changes to complex formation. Stable crystalline complexes with the composition $\mathrm{UO}_{2}\left(\mathrm{NO}_{3}\right)_{2} \mathrm{Me}_{2} \mathrm{CO} \cdot 3 \mathrm{H}_{2} \mathrm{O}$ and $\mathrm{UO}_{2}\left(\mathrm{NO}_{3}\right)_{2} \mathrm{MeEtCO} \cdot 3 \mathrm{H}_{2} \mathrm{O}$ could in fact be crystallized from these solutions. A similar complex, $\mathrm{UO}_{2}\left(\mathrm{NO}_{3}\right)_{2} \mathrm{Et}_{2} \mathrm{O} \cdot 3 \mathrm{H}_{2} \mathrm{O}$ was obtained from ethyl ether.

A similar study was carried out by Kaplan, Hildebrandt and Ader (1950a), who measured the spectra of uranyl nitrate solutions in methyl isobutyl ketone ("hexone"), cyclohexanone, and acetone. Since nitrates of organic bases are 


\section{8}

known to enhance the extractability of uranyl nitrate into methyl isobutyl ketone, the effect of the se compounds on the uranyl spectrum also was. investigated.

Figure 2.11 shows that the absorption spectra of uranyl nitrate (hexahydrate ?) are very similar in the three ketones. Beer's law is followed (in hexone) at least up to $0.1 \mathrm{M}$. Addition of tetrabutyl ammonium nitrate, $\mathrm{NBu}_{4} \mathrm{NO}_{3}$, (as well as that of tributylammonium nitrate, pyridinium nitrate or methyl isobutyl ketazinium nitrate) produces a striking spectral change. Four bands in the long-wave part of the spectrum become strongly enhanced, without apparent change in their positions. The increase of the absorption coefficient in this part of the spectrum is a linear function of concentration of the added tetrabutyl ammonium nitrate; the increase ceases abruptly when a molecular ratio $\left[\mathrm{UO}_{2}\left(\mathrm{NO}_{3}\right)_{2}\right]: \mathrm{NBu}_{4} \mathrm{NO}_{3}=1$ is reached. This points to the formation of a 1 : l complex, for which the following composition is suggested:

$$
\mathrm{UO}_{2}\left(\mathrm{NO}_{3}\right)_{2}+\mathrm{NO}_{3}^{-} \rightleftharpoons \mathrm{UO}_{2}\left(\mathrm{NO}_{3}\right)_{3}^{-}
$$

The method of continuous variations (comparison of spectra of mixtures with constant total amount of the two nitrates, but varying proportion, $x$, of uranyl nitrate) showed the average absorption coefficient (at 455 and $470 \mathrm{~m} \mu$ ) to rise with $x$ up to $x=0.5$, and then to decrease - as expected for a $1: 1$ complex whose absorption is stronger than that of the two components (Figure 2.12). The linearity of the change, and the consequent extreme sharpness of the peaks at $x=0.5$, indicate that the complex is very stable.

Kaplan et a1. point out that the argument does not depend on the extent of the ionic dissociation of uranyl nitrate in the organic solvent in the absence of $\mathrm{NBu}_{4} \mathrm{NO}_{3}$; the maximum in Figure 2.11 corresponds to three nitrate radicals present per one uranyl group.

A similar spectral change can be produced by the addition of nitric acid (instead of $\mathrm{NBu}_{4} \mathrm{NO}_{3}$ ) to a solution of uranyl nitrate in hexone. However, even at a nitric acid concentration of $0.78 \mathrm{M}$, the absorption between 420 and $480 \mathrm{~m} \mu$ is increased only about one-half as much as it is in $0.02 \mathrm{M} \mathrm{NBu} \mathrm{NO}_{3}$. The authors suggest that nitric acid addition leads to an equilibrium

$$
\mathrm{UO}_{2}\left(\mathrm{NO}_{3}\right)_{2}+\mathrm{HNO}_{3} \stackrel{\mathrm{K}}{=} \mathrm{HUO}_{2}\left(\mathrm{NO}_{3}\right)_{3}
$$

and that the neutral complex $\mathrm{HUO}_{2}\left(\mathrm{NO}_{3}\right)_{3}$ has practically the same spectrum as the complex ion $\mathrm{UO}_{2}\left(\mathrm{NO}_{3}\right)_{3}^{-}$. With these two assumptions, they calculated:

$$
\mathrm{K}=1.1 \pm 0.2=\frac{\left[\mathrm{HUO}_{2}\left(\mathrm{NO}_{3}\right)_{3}\right]}{\left[\mathrm{UO}_{2}\left(\mathrm{NO}_{3}\right)_{2}\right]\left[\mathrm{HNO}_{3}\right]}
$$

The close agreement they find between $K$ values calculated from two absorption vs. nitric acid concentration curves (at 454 and $469 \mathrm{~m} \mu$, respectively) by using for the complex ion the (previously determined) extinction coefficients of the complex molecule, is quoted by them as confirmation of the postulated identity of the two spectra. 


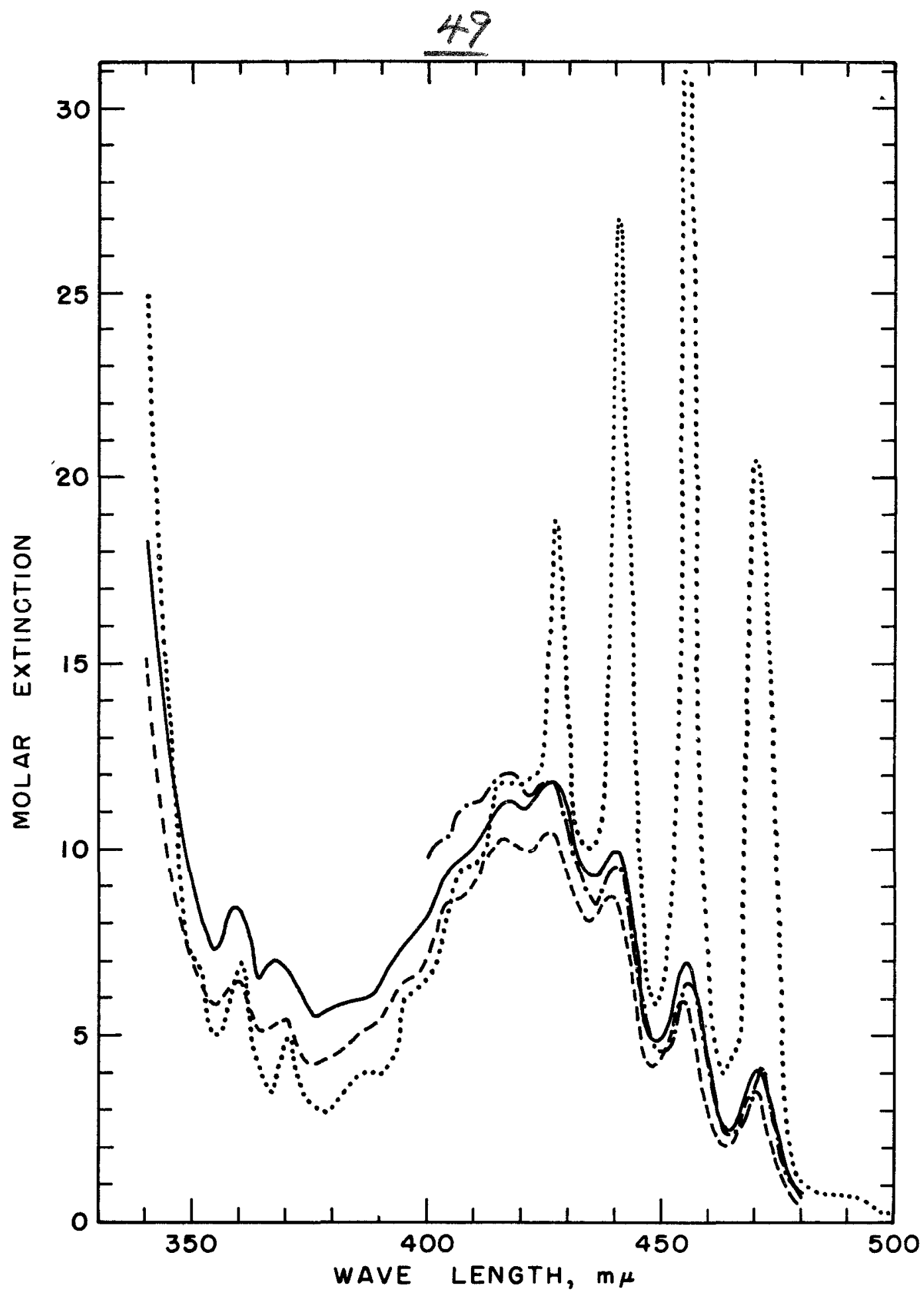

FIG.2.II-ABSORPTION SPECTRA OF URANYL NITRATE IN SOME KETONIC SOLVENTS.

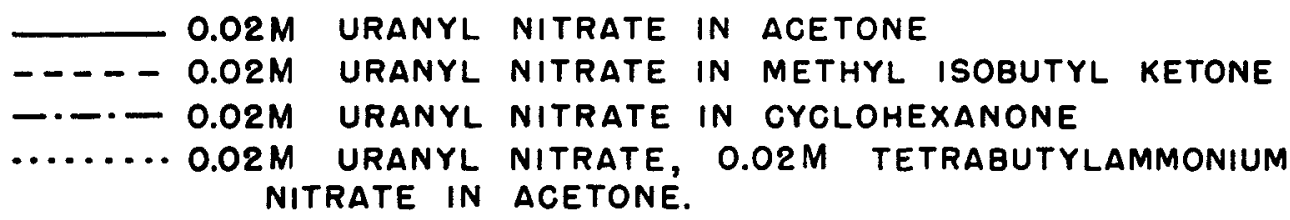




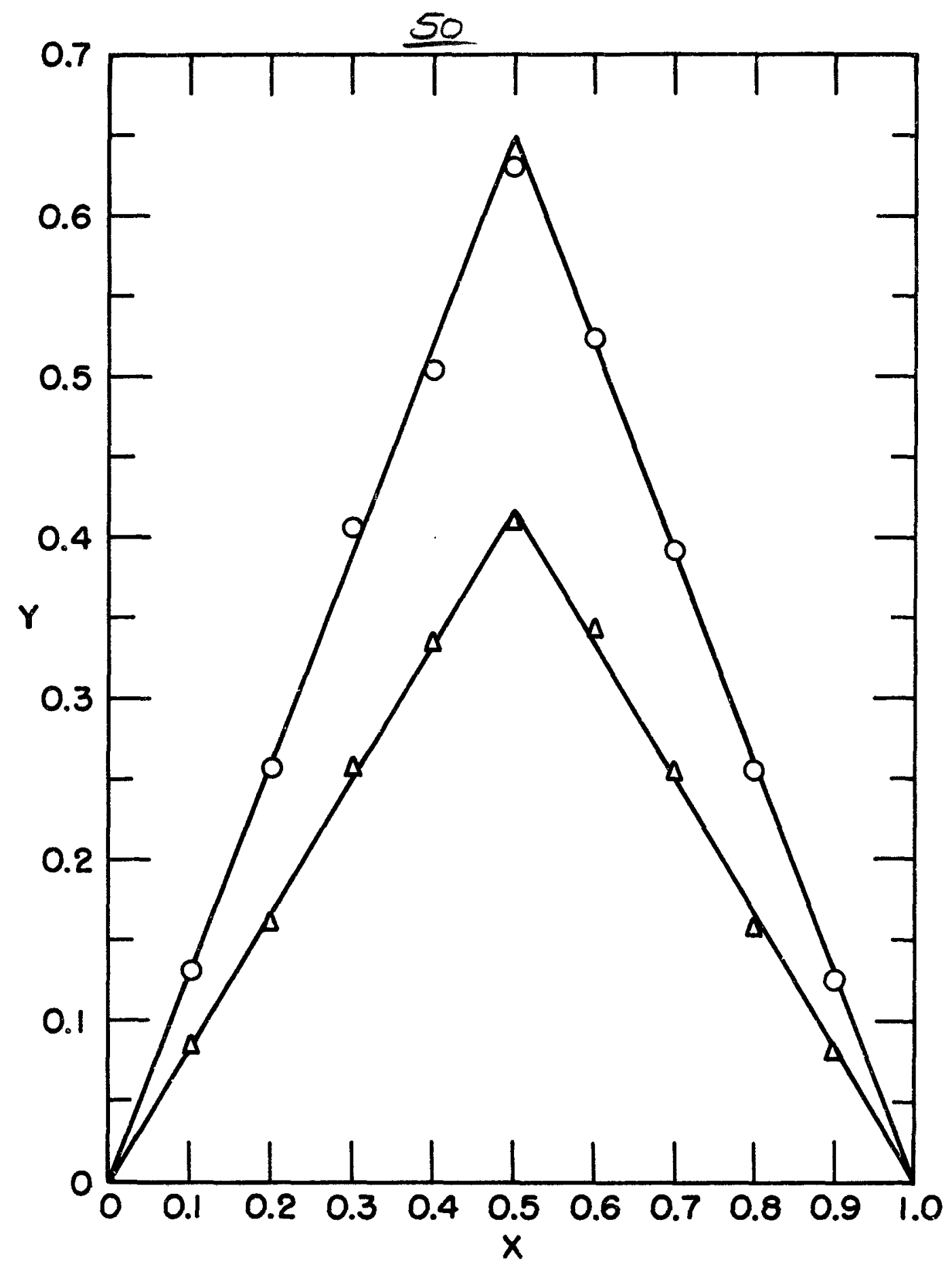

FIG.2.12-REACTION BETWEEN URANYL NITRATE AND TETRABUTYLAMMONIUM NITRATE IN METHYL ISOBUTYL KETONE.

$$
\begin{array}{ll}
O & 455 \mathrm{~m} \mu \\
\Delta & 470 \mathrm{~m} \mu
\end{array}
$$


Adding $\mathrm{NBu}_{4} \mathrm{NO}_{3}$ to a $\mathrm{UO}_{2} \mathrm{NO}_{3}$ solution containing large excess of nitric acid causes a further sharp rise of the absorption bands, even if the amount of organic nitrate added $(\sim 0.1 \mathrm{M})$ is small compared to that of the nitric acid already present $(\sim 1 \mathrm{M})$. The effect of $\mathrm{NBu}_{4} \mathrm{NO}_{3}$ is not quite as strong in the presence as in the absence of nitric acid, and the final spectrum, obtained upon. "saturation" with $\mathrm{NBu}_{4} \mathrm{NO}_{3}$, is the same with and without acid. Kaplan et al. pointed out that the addition of a certain amount of strong nitric acid also implies the addition of 1.6 molecules of water per molecule of added nitric acid; apparently the presence of this amount of water does not affect significantly the spectrum of the uranyl trinitrate complex.

Comparison of the action of several nitrates shows $\mathrm{NBu}_{4} \mathrm{NO}_{3}$ and $\mathrm{NPr}_{4} \mathrm{NO}_{3}(\mathrm{Pr}=\mathrm{n}$-propyl) to be equally effective (in acetone as solvent); with a tertiary amine $(2-n$-hexylpyridine), complexing is less complete (88\% in $0.02 \mathrm{M} \mathrm{UO}_{2}\left(\mathrm{NO}_{3}\right)_{2}+0.02 \mathrm{M}$ hexylpyridinium nitrate). This cannot be ascribed to an acid-base dissociation of $\mathrm{HNC}_{11} \mathrm{H}_{17} \mathrm{NO}_{3}\left(\rightleftharpoons \mathrm{HNO}_{3}+\mathrm{NC}_{11} \mathrm{H}_{17}\right)$, since addition of nitric acid does not affect the absorption. Rather, one has to assume a relatively low complexing constant of the tertiary amine $\left(\sim 3 \times 10^{3}\right.$, as against $>10^{5}$ with the quaternary ammonium salts). In hexone solution, too, pyridinium nitrate proves to be a less effective complexing agent than the quaternary ammonium nitrates. This (as well as the still lesser effect of nitric acid) may be related to the stronger complexing action of $\mathrm{NO}_{3}^{-}$ions compared to $\mathrm{RNO}_{3}$ molecules. (The larger size of the anion $\mathrm{UO}_{2}\left(\mathrm{NO}_{3}\right)_{3}^{-}$, compared to $\mathrm{NO}_{3}^{-}$, ought to make the ionization tendency of the complex $\mathrm{RUO}_{2}\left(\mathrm{NO}_{3}\right)_{3}$ stronger than that of the molecule $\mathrm{RNO}_{3}$.)

The molecule $\mathrm{UO}_{2}\left(\mathrm{NO}_{3}\right)_{2}$ is, according to the estimate of Kaplan et al., practically non-ionized in ketonic solvents, such as acetone or hexone, in the concentrations used, while molecules such as $\mathrm{NBu}_{4} \mathrm{NO}_{3}$ may be 40 or $70 \%$ dissociated in these solvents. Consequently, the significant complexing processes are those coupling the neutral molecules $\mathrm{UO}_{2}\left(\mathrm{NO}_{3}\right)_{2}$ with the molecules $\mathrm{RNO}_{3}$ and the ions $\mathrm{NO}_{3}^{-}$. The complexing is more stable the stronger the dissociation $\mathrm{RNO}_{3} \longrightarrow \mathrm{R}^{+}+\mathrm{NO}_{3}^{-}$.

The neutral complex $\mathrm{RUO}_{2}\left(\mathrm{NO}_{3}\right)_{3}$ itself undergoes ionic dissociation into $\mathrm{R}^{+}$and $\mathrm{UO}_{2}\left(\mathrm{NO}_{3}\right)_{3}^{-}$, while the neutral molecules $\mathrm{UO}_{2}\left(\mathrm{NO}_{3}\right)_{2}$ disproportionate into $\mathrm{UO}_{2} \mathrm{NO}_{3}^{+}$and $\mathrm{UO}_{2}\left(\mathrm{NO}_{3}\right)_{3}^{-}$. Trinitratouranyl anions can thus arise in three different ways: by association of uranyl nitrate with $\mathrm{NO}_{3}^{-}$ions, by association of the same salt with organic nitrates followed by ionic dissociation, and by disproportionation.

As mentioned before, the authors assume the spectroscopical difference between ionized and non-ionized complexes, $\mathrm{UO}_{2}\left(\mathrm{NO}_{3}\right)_{3}^{-}$and $\mathrm{RUO}_{2}\left(\mathrm{NO}_{3}\right)$, to be insignificant; if this is so, then the concentration ratio of these two forms cannot be derived from spectroscopic observations.

Further evidence for the formation of the trinitrato-uranyl complex is adduced by Kaplan et al. from solubility and solvent distribution measurements, and ionic transference observations. 


\section{2}

The same investigators (Kaplan, Hildebrandt and Ader, 1950b) also measured the spectra of uranyl nitrate in dioxane, pyridine, propanol, chloroform and other solvents, with and without addition of tetrabutyl ammonium nitrate, or of tertiary ammonium nitrates.

In some of the solutions studied, a darkening of color and turbidity appeared after several hours standing, indicating slow reaction of uranyl nitrate with the solvent. In cellosolve and dibutyl carbitol, the reaction occurred within a few minutes, making accurate spectroscopic measurements impossible.

All spectra had in common a broad band extending (in $0.02 \mathrm{M}$ solution) from about 380 to $500 \mathrm{~m} \mu$, with a peak around $425 \mathrm{~m} \mu$. The most important difference between the various spectra is in the four maxima between 420 and $480 \mathrm{~m} \mu$, whose enhancement by organic nitrates was first noted in ketones (Figure 2.11). The same strong effect of organic nitrates - attributed above to the formation of a trinitro complex - was noted in some other solvents, while in others only a minor effect was observed.

Figure 2.13 shows the spectra of uranyl nitrate in water, in dilute $(0.5 \mathrm{M})$ and strong $(16 \mathrm{M})$ nitric acid. The somewhat stronger absorption in water compared to dilute nitric acid must be due to partial hydrolysis (cf. Section 1). The effect of concentrated nitric acid in enhancing the longwave peaks, presumably by trinitrate complex formation, was mentioned above.

The similar effect of acetone, 31 so mentioned above (see Figure 2.11) is represented in Figure 2.14 in relation to the water content of the acetone, and the addition of tetrabutylammonium nitrate.

The absorption spectrum of $\mathrm{UO}_{2}\left(\mathrm{NO}_{3}\right)_{2}$ in dioxane (Figure 2.15) is rather similar to that in water, but the maxima in the 400-430 mu region are somewhat flattened, while the structure at longer waves is somewhat better resolved. It is, however, much less pronounced than in acetone, even in the presence of $\mathrm{NBu}_{4} \mathrm{NO}_{3}$. Presence of up to $20 \%$ water causes a general enhancement of the absorption curve, without significant change in shape, but at $40 \%$ water the spectrum acquires the shape typical of aqueous solutions. $\mathrm{NBu}_{4} \mathrm{NO}_{3}$ cannot be added to pure dioxane solution without causing precipitation; addition of 2-hexylpyridinium nitrate causes a marked enhancement of the long-wave bands, but the effect is much weaker than in ketonic solvents.

The absorption curves in ethanol and propanol (Figure 2.16) are similar to those in dioxane above $\overline{430 \mathrm{~m}} \mu$, but the absorption is stronger. Addition of $0.04 \mathrm{M} \mathrm{NBu} \mathrm{NO}_{3}$ to propanol solution, or of $0.04 \mathrm{M} \mathrm{HNEt}_{3} \mathrm{NO}_{3}$ to ethanol solution, raises the absorption somewhat, but causes no selective enhancement of the long-wave bands. 


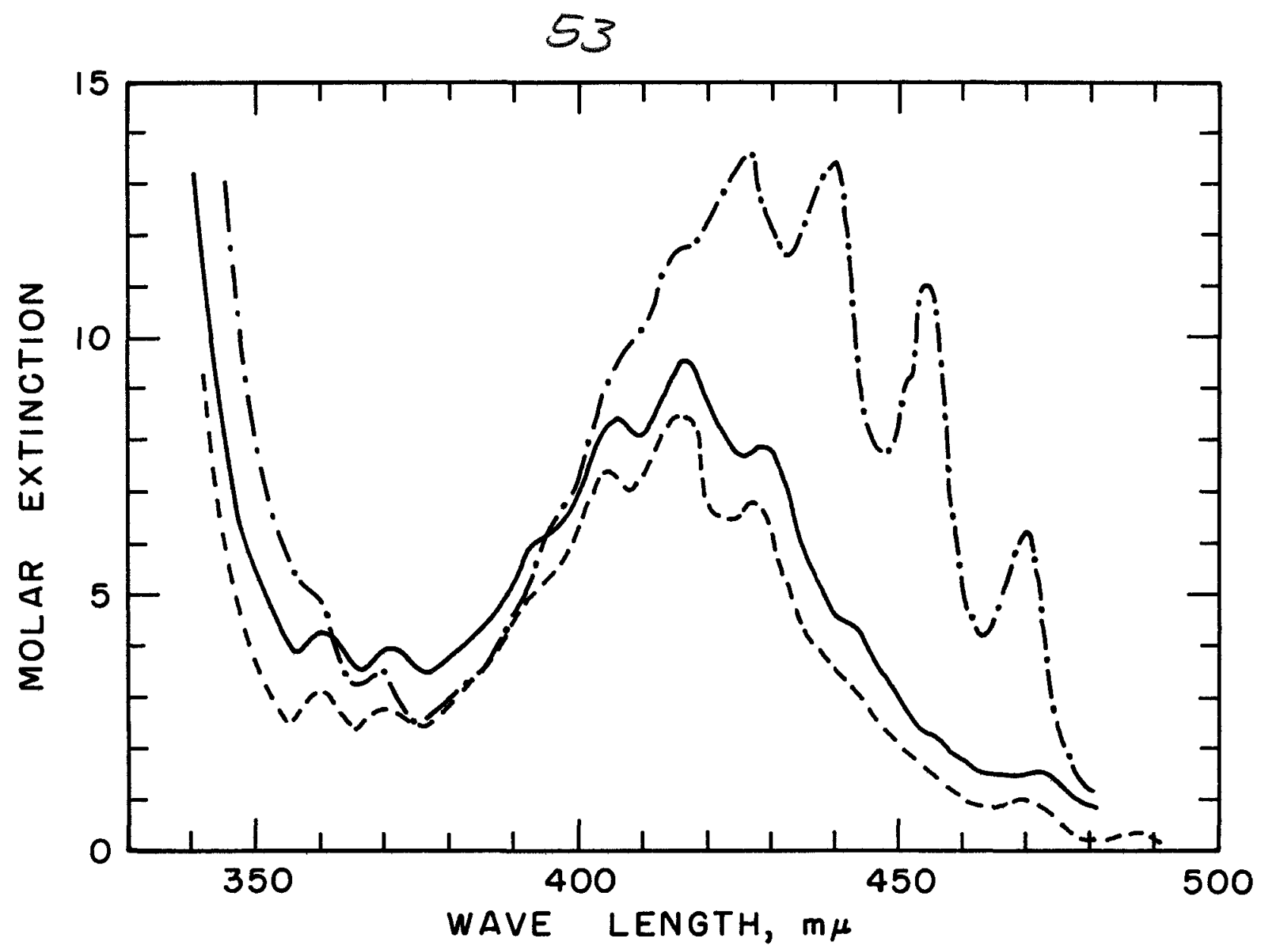

FIG.2.I3-ABSORPTION SPECTRA OF URANYL NITRATE IN SOME AQUEOUS SOLUTIONS.

$$
\begin{aligned}
& -0.02 \mathrm{M} \mathrm{UO} 2\left(\mathrm{NO}_{3}\right)_{2} \text { IN } \mathrm{H}_{2} \mathrm{O} \\
& ----0.00974 \mathrm{M} \mathrm{UO}_{2}\left(\mathrm{NO}_{3}\right)_{2} \mathrm{IN} 0.514 \mathrm{M} \mathrm{HNO}_{3} \\
& -\cdot-.-0.02 \mathrm{M} \mathrm{UO}_{2}\left(\mathrm{NO}_{3}\right)_{2} \text { IN } 16 \mathrm{M} \mathrm{HNO}
\end{aligned}
$$


54

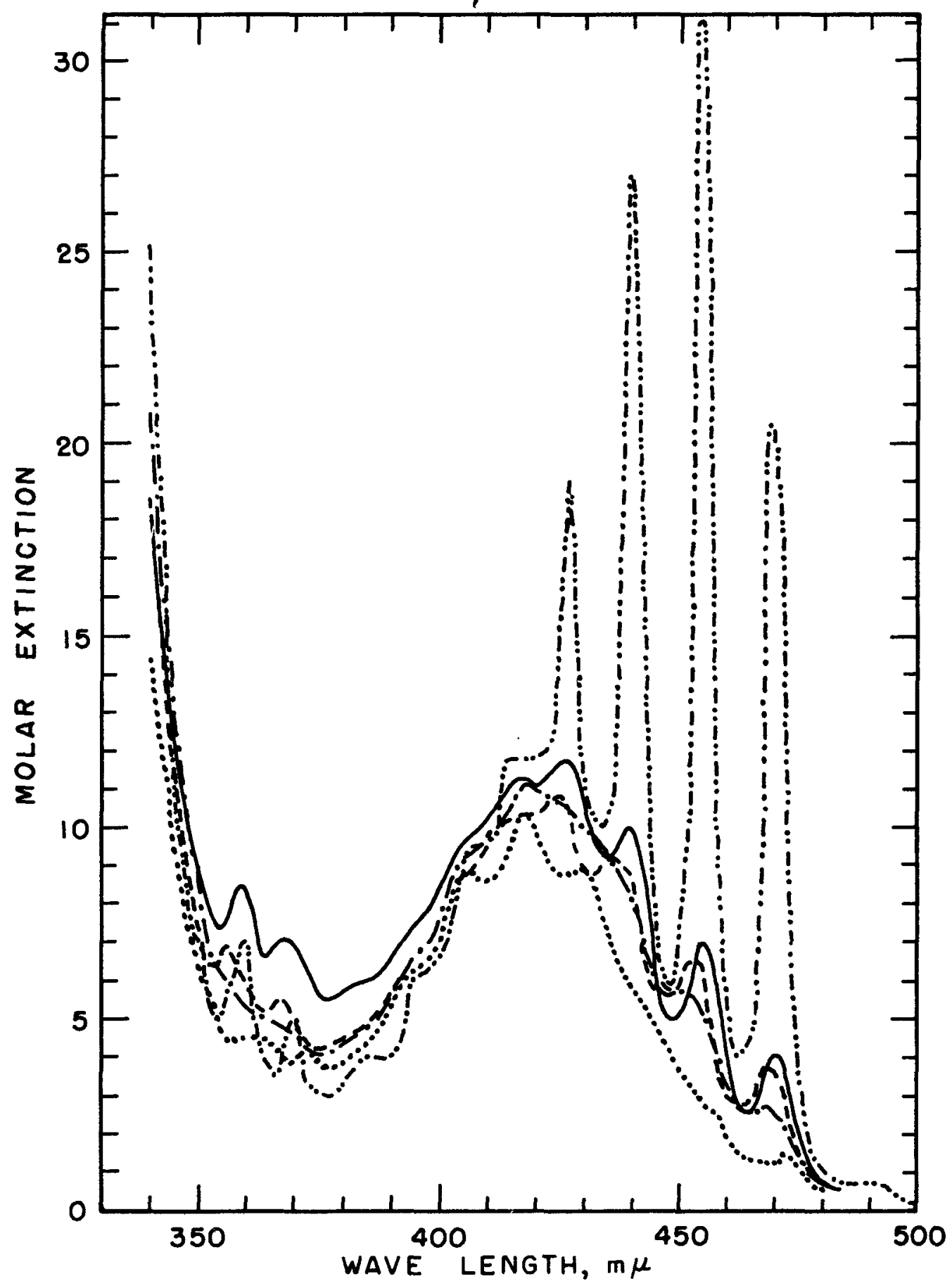

FIG. 2.14 ABSORPTION SPECTRA OF URANYL NITRATE IN SOME ACETONE SOLUTIONS.

$$
\mathrm{UO}_{2}\left(\mathrm{NO}_{3}\right)_{2} \cdot 6 \mathrm{H}_{2} \mathrm{O}=0.02 \mathrm{M}
$$

DRY ACETONE

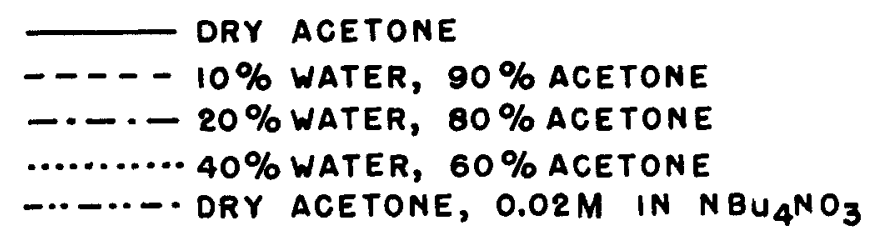




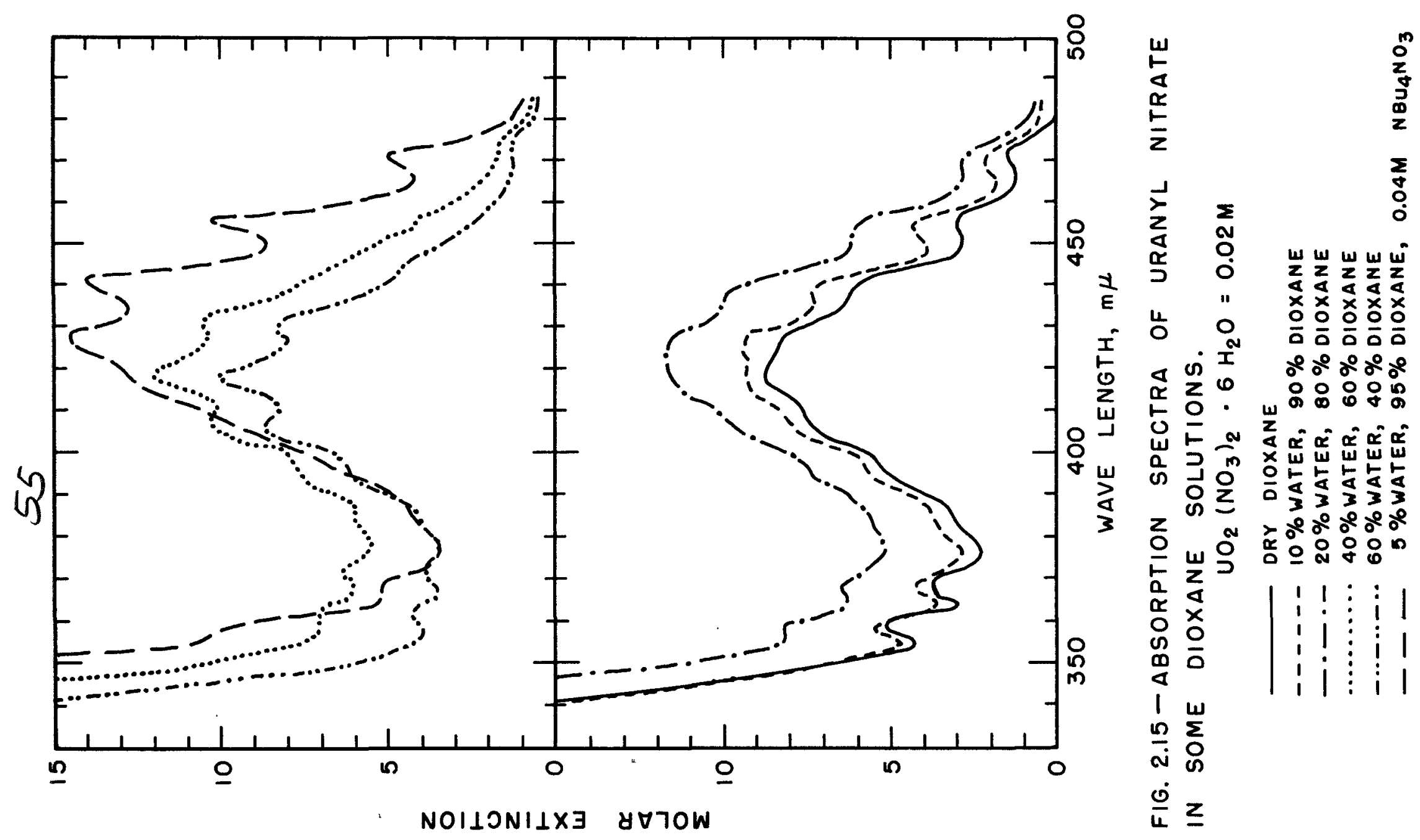




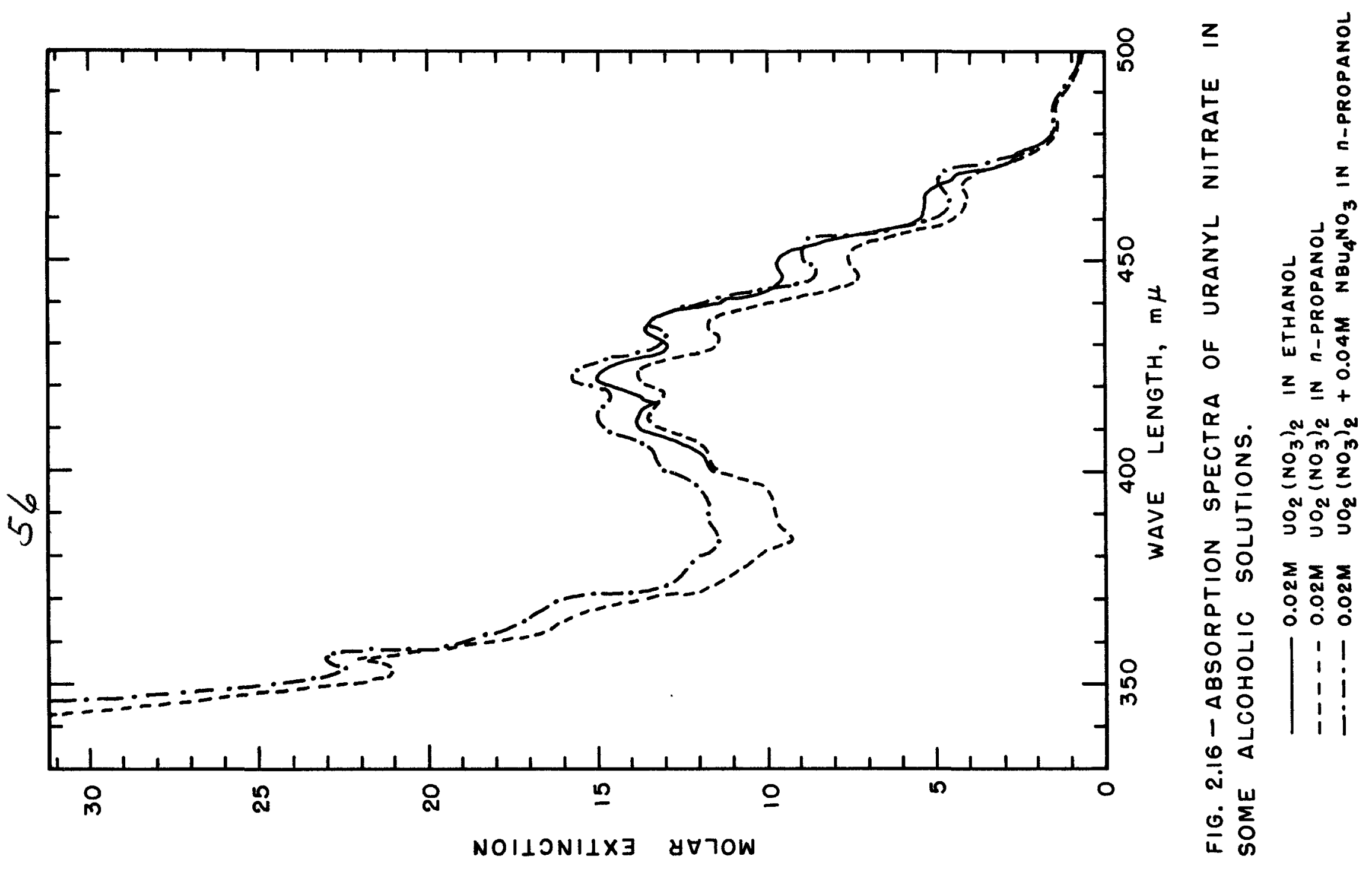




\section{7}

In chloroform (containing about $0.7 \%$ alcohol), $\mathrm{UO}_{2}\left(\mathrm{NO}_{3}\right)_{2} \cdot 2 \mathrm{H}_{2} \mathrm{O}$ is appreciably soluble, so that solutions $0.015 \mathrm{M}$ in uranyl nitrate could be prepared. Its spectrum (Figure 2.17) is similar to the solution of uranyl nitrate hexahydrate in dioxane. $\mathrm{NBu}_{4} \mathrm{NO}_{3}$ increases the solubility markedly, and the resulting solution has the same type of spectrum as is found in strongly complexed ketonic solutions.

In pyridine, the absorption spectrum of uranyl nitrate is quite different from that in other solvents (Figure 2.18). Addition of $\mathrm{NBu}_{4} \mathrm{NO}_{3}$ causes a general increase in absorption above $380 \mathrm{~m} \mu$, and a shift of the peak to longer waves, but produces no selective enhancement of the bands above $410 \mathrm{~m} \mu$.

Figure 2.19 shows the spectra of $\mathrm{UO}_{2}\left(\mathrm{NO}_{3}\right)_{2} \cdot 6 \mathrm{H}_{2} \mathrm{O}$ dissolved in nitroethane, ethyl acetate, glacial acetic acid, and tetraethylene glycol dibutylether. They are rather similar to that in acetone, and in all of them, with the exception of that in acetic acid, addition of an organic nitrate produces the same selective enhancement, although not always in equally extreme form. In acetic acid, the changes are more complex, probably indicating complexing with acetate ions.

For comparison, the spectrum of uranyl perchlorate solutions in methyl isobutyl ketone (with and without $\mathrm{NBu}_{4} \mathrm{NO}_{3}$ ) was also measured (Figure 2.20). The changes are similar to those described above for nitrate solutions.

Tables $2.12 \mathrm{~A}$ and $2.12 \mathrm{~B}$ summarize the above-described results. In discussing the absorption curves in Figures 2.13-2.19, Kaplan et al. note that the spacing of the bands is approximately the same $\left(710-746 \mathrm{~cm}^{-1}\right.$; average $727 \mathrm{~cm}^{-1}$ ) in all six solvents where it could be measured (the bands in pyridine are too diffuse).

The most remarkable result is the sharpness of the bands ascribed to the trinitrouranyl complex. The authors compare this spectrum (above $380 \mathrm{~m} \mu$ ) with that of solid uranyl cesium nitrate. (For the sake of this comparison, the sharp lines of the crystal, as measured by Dieke et al. (of Chapter 1) at $20^{\circ} \mathrm{K}$, are "smeared out" over a $2 \mathrm{~m} \mu$ range to simulate the effect of temperature. The lines of the "magnetic" series are omitted because they are known to disappear with rising temperature.) Kaplan et al. find a remarkable similarity between the two spectra (Figure 2.21), and conclude that the position of the three $\mathrm{NO}_{3}^{-}$ions in respect to the $\mathrm{UO}_{2}^{++}$ion must be similar in both cases. [In $\mathrm{UO}_{2} \mathrm{Rb}\left(\mathrm{NO}_{3}\right)_{3}$, where this position is known from $\mathrm{X}-\mathrm{ray}$ analysis, the three nitrate groups are arranged symmetrically around the O-U-O axis.] 
58

Table 2. 12A

THE EFFECT OF ADDED NITRATES, RNO 3 , ON THE ABSORPTION OF

URANYL NITRA TE IN ORGANIC SOLVENTS

\begin{tabular}{|c|c|c|c|c|c|c|}
\hline Solvent & $\begin{array}{c}\mathrm{H}_{2} \mathrm{O} \\
\%\end{array}$ & $\mathrm{R}$ & $\begin{array}{c}\left(\mathrm{RNO}_{3}\right) \\
\mathrm{M}\end{array}$ & $\epsilon_{470}-\epsilon_{464}(\mathrm{a})$ & $\epsilon_{455}-\epsilon_{448}(\mathrm{a})$ & $\epsilon_{441}-\epsilon_{434}(\mathrm{a})$ \\
\hline \multirow{4}{*}{ Acetone } & 0 & & 0 & 1.6 & 2.1 & 0.5 \\
\hline & 0 & $\mathrm{NBu}_{4}{ }^{(\mathrm{d})}$ & $0.02^{(g)}$ & 15.8 & 24.9 & 16.6 \\
\hline & 10 & $\mathrm{NBu}_{4}^{4}(\mathrm{~d})$ & 0.02 & 2.9 & 4.3 & \\
\hline & 20 & $\mathrm{NBu}_{4}{ }^{(\mathrm{d})}$ & 0.02 & 0.7 & 1.0 & \\
\hline \multirow[t]{2}{*}{ Nitroethane } & 0 & & 0 & 2.4 & 3.3 & 1.9 \\
\hline & 0 & $\mathrm{HNEt}_{3}(\mathrm{e})$ & $0.02(\mathrm{~g})$ & 13.8 & 22.2 & 14.9 \\
\hline Chloroform $^{(b)}$ & & $\mathrm{NBu}_{4}{ }^{(\mathrm{d})}$ & $0.02^{(\mathrm{g})}$ & 12.3 & 18.7 & 12.9 \\
\hline \multirow[t]{2}{*}{ Ethyl acetate } & 0 & & 0 & 0.7 & 1.3 & 0.4 \\
\hline & 0 & $\mathrm{HNEt}_{3}{ }^{(\mathrm{e})}$ & 0.02 & 10.3 & 15.9 & 11.4 \\
\hline \multirow{3}{*}{$\mathrm{C}_{16} \mathrm{H}_{34} \mathrm{O}_{5}{ }^{(\mathrm{c})}$} & 0 & & 0 & 0.7 & 0.8 & 0.5 \\
\hline & 0 & $\mathrm{HNEt}_{3}(\mathrm{e})$ & 0.02 & 9.2 & 13.5 & 9.5 \\
\hline & 0 & $\mathrm{HNEt}_{3}{ }^{(\mathrm{e})}$ & 0.04 & 10.6 & 17.3 & 13.0 \\
\hline \multirow[t]{5}{*}{ Dioxane } & 0 & $\mathrm{HNC}_{11} \mathrm{H}_{17}{ }^{(\mathrm{f})}$ & 0.02 & 3.2 & 5.1 & 2.7 \\
\hline & 0 & $\mathrm{HNC}_{11} \mathrm{H}_{17}(\mathrm{f})$ & 0.04 & 5.2 & 8.3 & 5.4 \\
\hline & 0 & $\mathrm{HNC}_{11} \mathrm{H}_{17}(\mathrm{f})$ & 0.08 & 6.5 & 10.8 & 7.5 \\
\hline & 5 & $\mathrm{NBu}_{4}(\mathrm{~d})$ & 0.02 & 0.5 & 1.3 & 0.4 \\
\hline & 5 & $\mathrm{NBu}_{4}{ }^{(d)}$ & 0.04 & 0.8 & 1.7 & 1.3 \\
\hline
\end{tabular}

(a) $\epsilon_{\lambda}=$ Molar extinction coefficient at $\lambda \mathrm{m} \mu$. Wave lengths of the maxima vary by $\pm 1 \mathrm{~m} \mu$ among the different solvents; minima vary by $\pm 2 \mathrm{~m} \mu$. Extinctions given are those at the actual maxima and minima in the particular solvent.

(b) Containing $0.7 \%$ e thanol.

(c) Tetrae thylene glycol dibutyl ether.

(d) Tetra-n-butylammonium.

(e) Trie thyla mmonium.

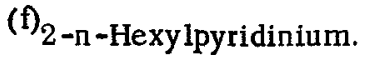

${ }^{(g)}$ Fur ther increase in the nitrate concentration caused no appreciable increase in the peak heights. 
59

Table 2.12B

SPACING OF THE ABSORPTION BANDS IN

URANYL NITRATE SOLUTIONS

\begin{tabular}{|l|c|c|c|}
\hline \multicolumn{1}{|c|}{ Solution } & $\begin{array}{c}\text { No. of Bands } \\
\text { Measured }\end{array}$ & $\begin{array}{c}\text { Average Spacing } \\
\mathrm{cm}^{-1}\end{array}$ & $\begin{array}{c}\text { Average Deviation } \\
\mathrm{cm}^{-1}\end{array}$ \\
\hline Water & 11 & 725 & 110 \\
Acetone & 10 & 735 & 80 \\
$\mathrm{UO}_{2}\left(\mathrm{NO}_{3}\right)_{3}^{-}$in & 10 & 722 & 80 \\
acetone & 4 & 710 & 27 \\
Nitroethane & 10 & 722 & 110 \\
Dioxane & 10 & 746 & 91 \\
Propanol & & Mean $727 \pm 9$ & 83 \\
\hline
\end{tabular}

In discussing the molecular species which may be present in the various solutions studied, Kaplan et al. noted that apart from the striking charge caused by formation of the trinitrouranyl complex, other spectroscopic changes observed were small, and thus difficult to analyze quantitatively. However, they thought to recognize six spectral types:

Type A - Sharp peaks at 426, 441,456, $470 \mathrm{~m} \mu$ (typical example: uranyl solution in acetone $+\mathrm{NBu}_{4} \mathrm{NO}_{3}$ ).

Type B - Distinct, but weaker peaks in same positions [e.g., $\mathrm{UO}_{2}\left(\mathrm{NO}_{3}\right)_{2}$ in acetone without $\mathrm{NBu}_{4} \mathrm{NO}_{3}$ ].

Type C - No marked peaks $>380 \mathrm{~m} \mu$, except for one broad maximum at $\sim 420 \mathrm{~m} \mu$ [e.g., $\mathrm{UO}_{2}\left(\mathrm{NO}_{3}\right)_{2}$ in dioxane].

Type D - Very little structure $>430 \mathrm{~m} \mu$; three peaks between 400 and $430 \mathrm{~m} \mu\left[\right.$ e.g., $\mathrm{UO}_{2}\left(\mathrm{NO}_{3}\right)_{2}$ in water].

Type E - Similar to type $\mathrm{C}$ above $440 \mathrm{~m} \mu$, but absorption stronger. Three peaks in the region 410-440 $\mathrm{m} \mu$; stronger absorption $<400 \mathrm{~m} \mu$ than in types $\mathrm{A}$ to $\mathrm{D}$; [e.g., $\mathrm{UO}_{2}\left(\mathrm{NO}_{3}\right)_{2}$ in propanol].

Type $\mathrm{F}$ - Diffuse absorption $\left[\mathrm{UO}_{2}\left(\mathrm{NO}_{3}\right)_{2}\right.$ in pyridine]. 
이

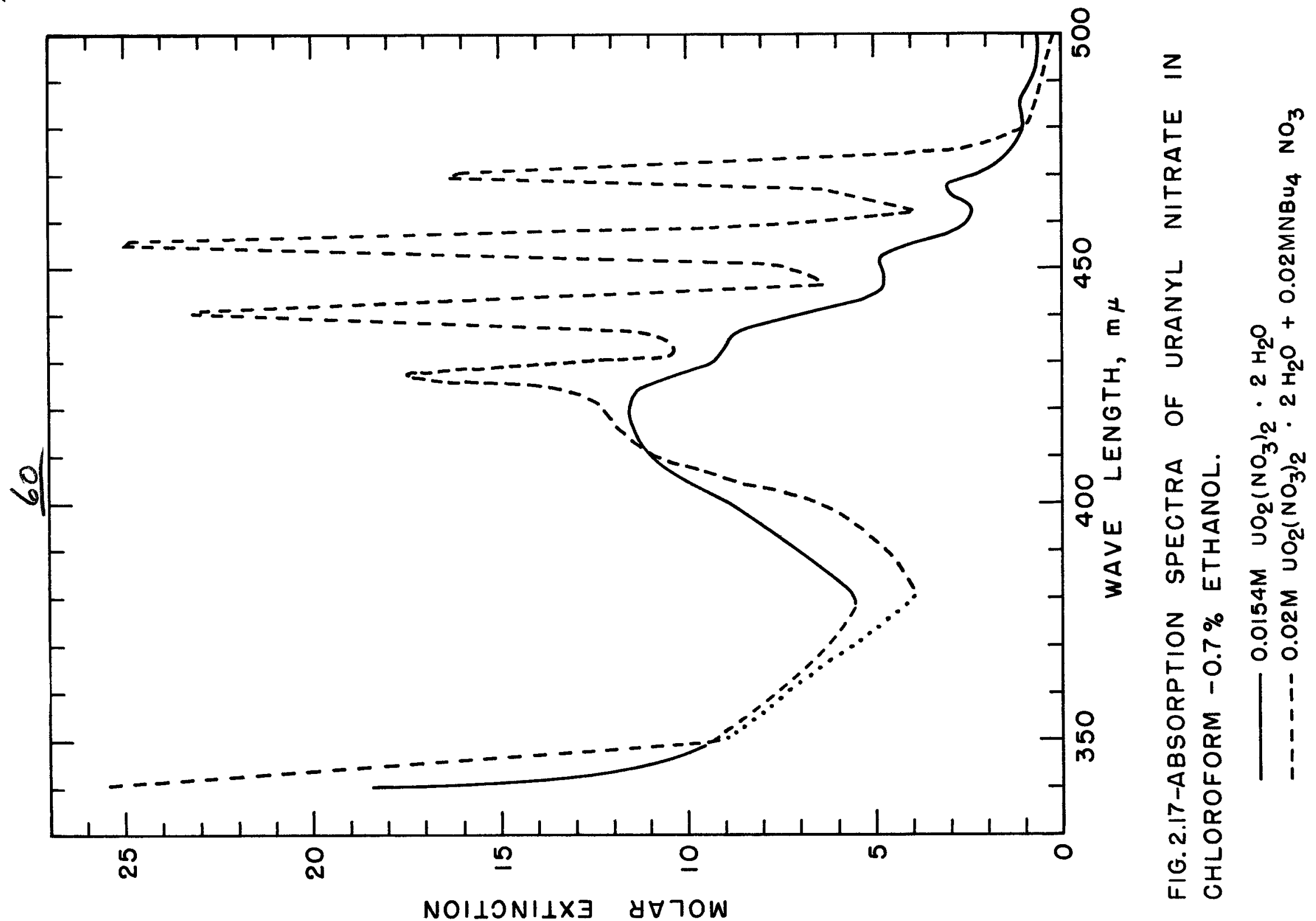




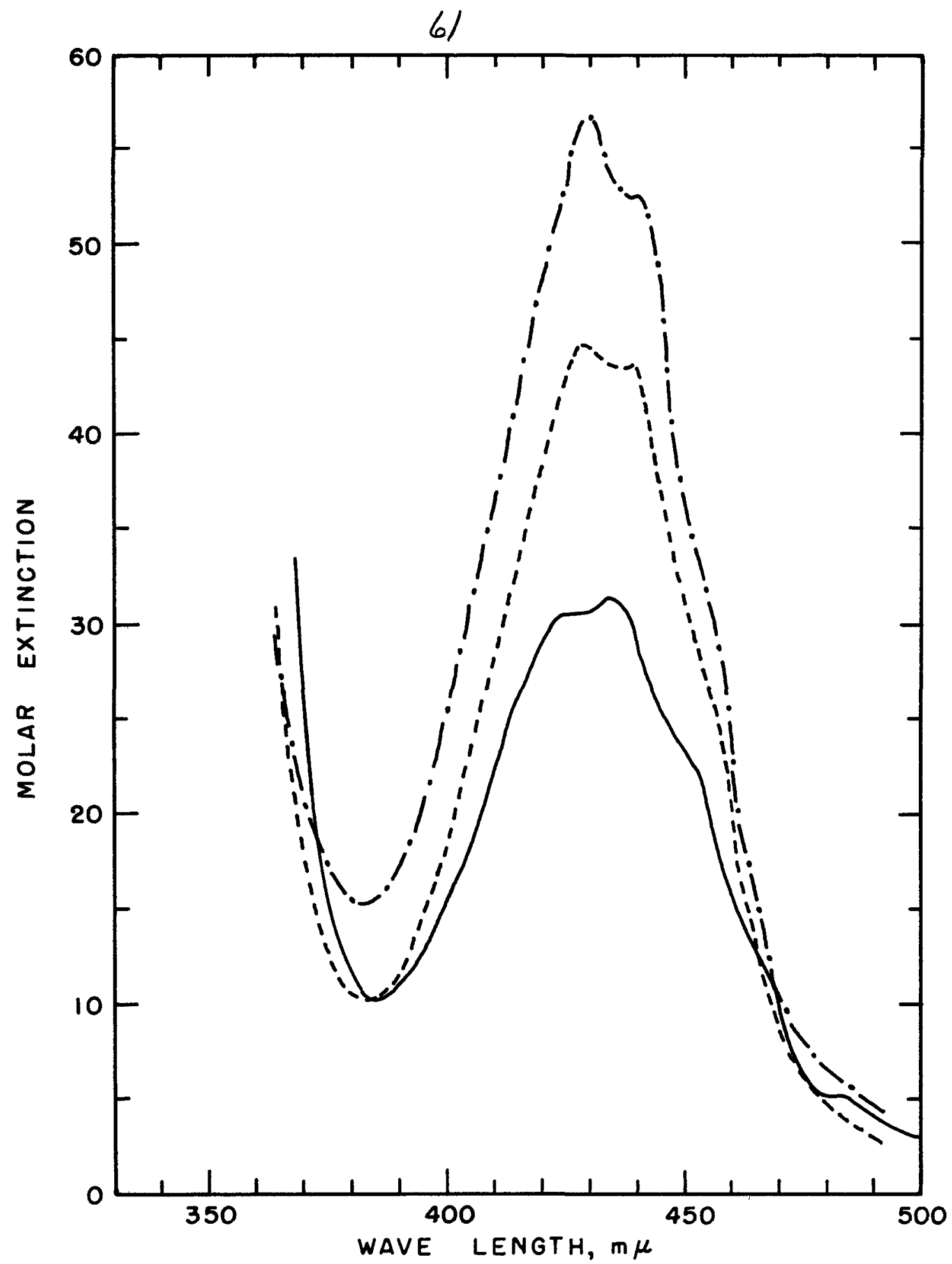

FIG. 2.18- ABSORPTION SPECTRA OF URANYL NITRATE IN PYRIDINE. $\quad \mathrm{UO}_{2}\left(\mathrm{NO}_{3}\right)_{2} \cdot 6 \mathrm{H}_{2} \mathrm{O}=0.02 \mathrm{M}$

$$
\begin{aligned}
& - \text { NO ADDED REAGENT } \\
& ----0.1 \mathrm{M} \mathrm{NBU}_{4} \mathrm{NO}_{3} \\
& -\cdots--0.8 \mathrm{M} \mathrm{NBU}_{4} \mathrm{NO}_{3}
\end{aligned}
$$




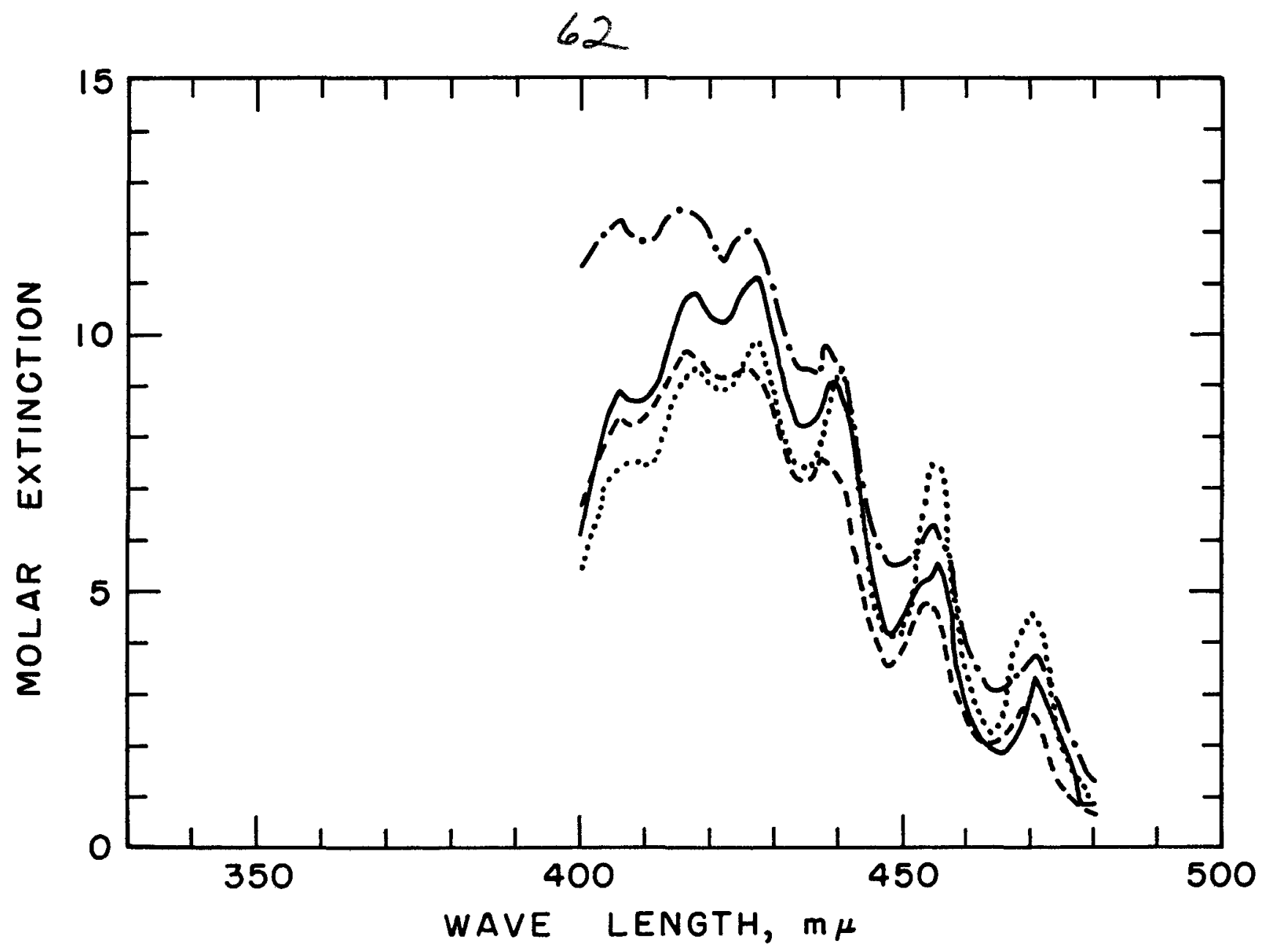

FIG. 2.19-ABSORPTION OF URANYL NITRATE IN VARIOUS SOLVENTS. $\quad \mathrm{UO}_{2}\left(\mathrm{NO}_{3}\right)_{2} \cdot 6 \mathrm{H}_{2} \mathrm{O}=0.02 \mathrm{M}$

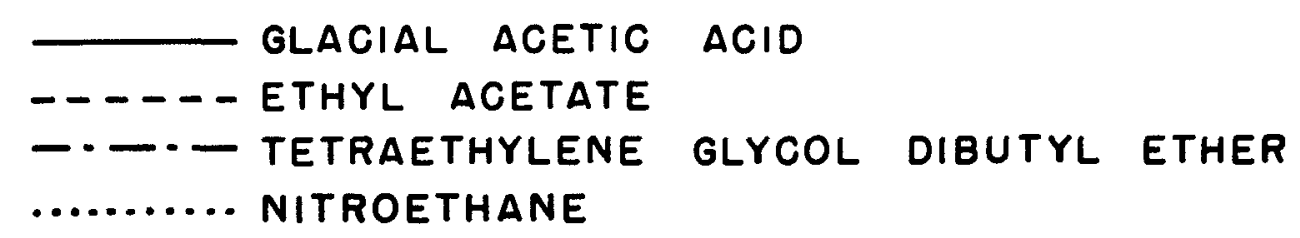




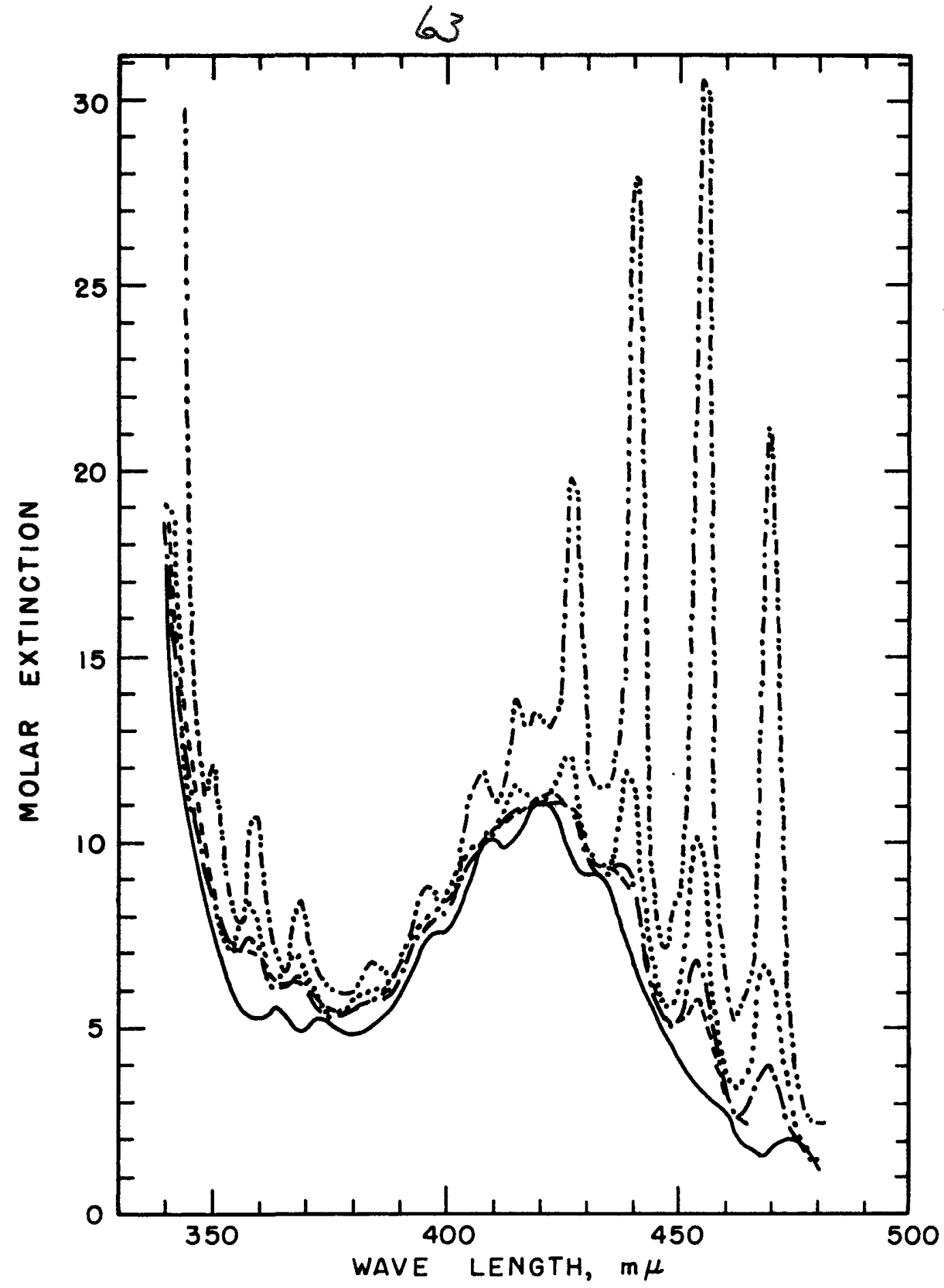

FIG. 2.20.-ABSORPTION SPECTRA OF METHYL ISOBUTYL KETONE SOLUTIONS CONTAINING URANYL PERCHLORATE. $\quad \mathrm{UO}_{2}\left(\mathrm{ClO}_{4}\right)_{2}=0.02 \mathrm{M}$

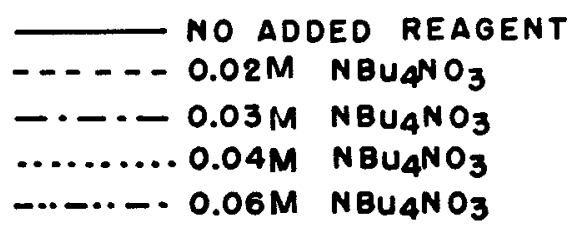




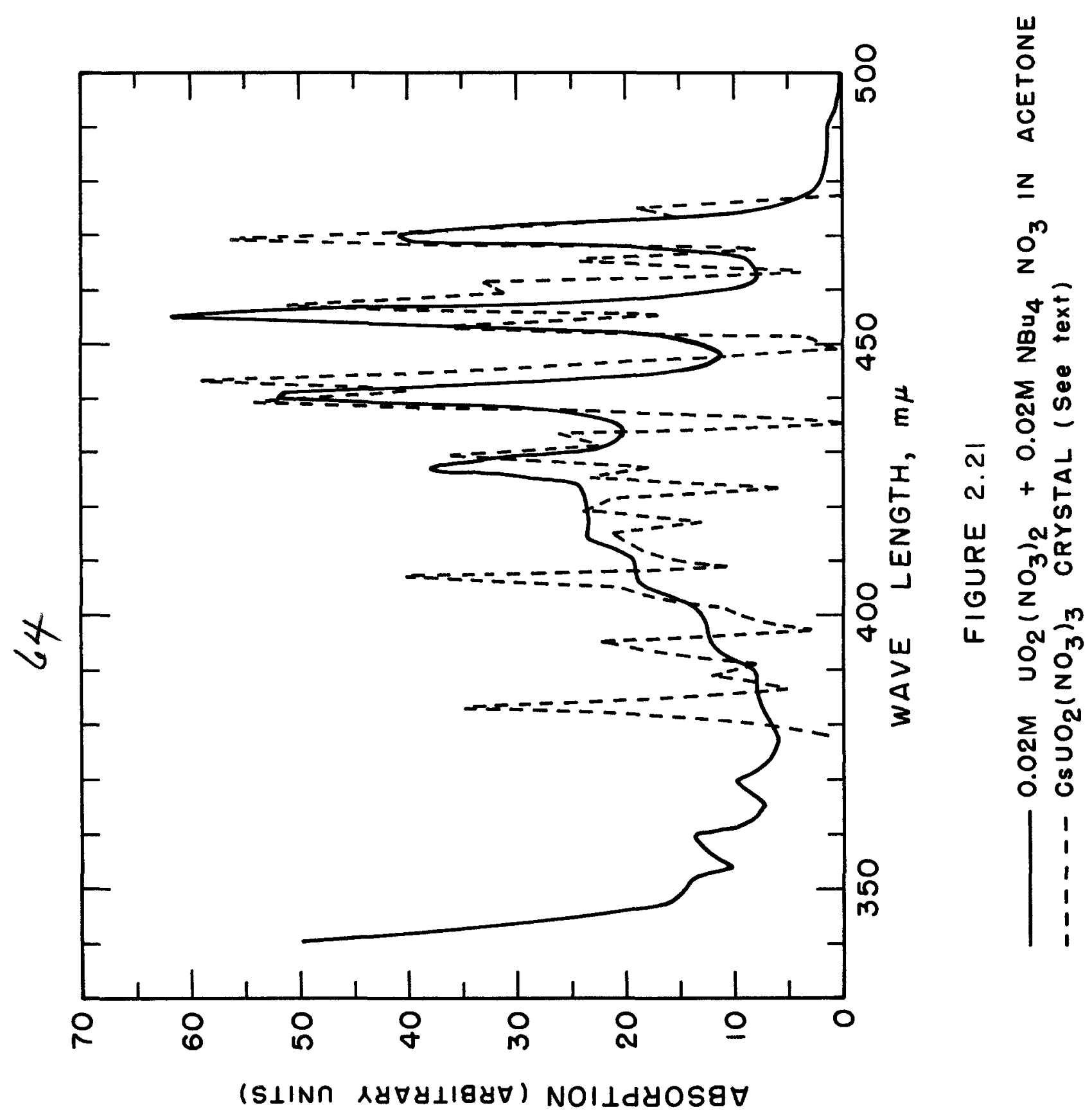




\section{5}

The authors interpreted spectra of the types $A, B, C$, and $D$ as indicative of a diminishing number of $\mathrm{NO}_{3}^{-}$ions in association with the $\mathrm{UO}_{2}^{++}$ion. Type $\mathrm{A}$ was ascribed above to the $\mathrm{UO}_{2}\left(\mathrm{NO}_{3}\right)_{3}^{-}$ion [or the $\mathrm{HUO}_{2}\left(\mathrm{NO}_{3}\right)_{3}$ molecule]. Type $\mathrm{B}$ may then indicate a dinitrate complex, $\mathrm{UO}_{2}\left(\mathrm{NO}_{3}\right)_{2}$, type $\mathrm{C}$, a mononitrocomplex, $\mathrm{UO}_{2} \mathrm{NO}_{3}^{+}$, and type $\mathrm{D}$ (exhibited, e.g., by uranyl nitrate in water) the non-complexed ion $\mathrm{UO}_{2}^{+}$. The existence of a dinitrocomplex is made plausible by quantitative analysis of the five curves in Figure 2.20. If trinitrate were the only complex formed, its concentration in the five solutions would have had to be $0,0.0067,0.01$, 0.013 , and $0.02 \mathrm{M}$, respectively; if, in addition to the trinitrate, only a (stable) mononitrate were formed, the trinitrate concentrations would have had to be $0,0,0.005,0.01$, and $0.02 \mathrm{M}$. With a (stable) dinitrate complex, the trinitrate concentrations would be zero in the first four solutions and $0.02 \mathrm{M}$ in the last one. The actual trinitrate concentrations, calculated from the curves on the assumption that the enhancement of absorption in the four peaks is caused by trinitrate alone, are as follows: $0,0.0016,0.0024,0.0052$, and $0.02 \mathrm{M}$. A plausible interpretation of these numbers is that a dinitrate complex does exist, and has absorption bands in the same positions as those of the trinitrate, but considerably weaker than the latter. If this hypothesis is correct, then the dinitrate complex predominates in $0.02 \mathrm{M}$ solutions of uranyl nitrate in the following solvents: $16 \mathrm{M} \mathrm{HNO}_{3}$, acetone, methyl isobutyl ketone, ethyl acetate, nitroethane and glacial acetic acid. Because of the low dielectric constant of solvents, such as dioxane, which show type C spectra (Figure 2.15), the mononitrate complex - which we assumed produces these spectra cannot be present in them as a free cation. The authors suggest that it is solvated and then associated with a solvated nitrate anion, thus:

$$
\left[\left(\mathrm{UO}_{2} \mathrm{NO}_{3}^{+}\right)_{\text {solv. }}\left(\mathrm{NO}_{3}^{-}\right)_{\text {solv. }}\right]
$$

Within a given spectral type, minor differences occur that can be attributed to solvation by different solvents. In the case of solvent mixtures containing water, partial hydrolysis also must be taken into consideration.

The peculiar effect of pyridine (type $F$ spectrum) can be tentatively attributed to coordination of $\mathrm{UO}_{2}^{+}$with the nitrogen atoms in pyridine molecules (in all the other cases, the only coordination taken into account was that with oxygen atoms).

The solvation of uranyl ions by alcohols must be particularly strong to account for the type $E$ spectra exhibited by solutions in these solvents. Addition of $\mathrm{NR}_{4} \mathrm{NO}_{3}$ leads to the formation of the trinitrate complex in acetone, methyl isobutyl ketone, ethyl acetate, nitroethane and chloroform, but not in acetic acid, dioxane, pyridine, or alcohols.

Some of these interpretations appear speculative, but they are quite similar to those suggested independently by other observers for the explanation of the spectra of other nitrates in mixed solvents. 


\section{6 \\ 4. RAMAN SPECTRUM AND INFRARED SPECTRUM OF URANYL SALT SOLUTIONS}

Pringsheim and Yost (1929) first observed the Raman spectrum of a concentrated uranyl sulfate solution (in sulfuric acid) and found a single frequency of $870 \mathrm{~cm}^{-1}$, obviously corresponding to the main vibrational frequency of the ground state of $\mathrm{UO}_{2}^{++}$, revealed by the fluorescence spectrum.

Conn and Wu (1938) investigated the Raman spectrum of saturated solutions of uranyl nitrate, chloride and sulfate, and found two vibrational frequencies (cf. Table 2.14). According to (Chap. 1), these are the symmetric and the bending frequency, respectively, of the $\mathrm{UO}_{2}^{++}$group. However, since the bending frequency should be "Raman-inactive" in linear molecules, Conn and Wu preferred an angular model of the uranyl ion, in

which the "symmetric" vibration $\longrightarrow \longrightarrow 0$ becomes

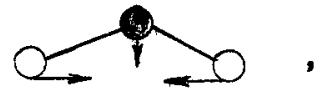

and the "bending" vibration 0 sult that both are now permitted in the Raman spectrum.

Satyanarayana (1942) used a saturated solution of uranyl chloride in water, adding potassium bromide to quench fluorescence. After $24 \mathrm{hr}$ exposure, with the mercury line $546.1 \mathrm{~m} \mu$ as exciting line, he was able to meas ure five Raman frequencies (Table 2.13).

Table 2.13

RAMAN FREQUENCIES OF $\mathrm{UO}_{2} \mathrm{Cl}_{2}$ IN WATER

(SATYANARAYANA, 1942)

\begin{tabular}{|l|r|r|r|r|r|}
\hline Raman frequency $\left(\mathrm{cm}^{-1}\right)$ & 197 & 226 & 853 & 865 & 909 \\
Intensity & 2 & 2 & 0 & 10 & 1 \\
Interpretation & $\nu_{\mathrm{b}}^{\prime \prime}$ & $\nu_{\mathrm{b}}^{\prime}$ & $\nu_{\mathrm{s}}^{\prime \prime}$ & $\nu_{\mathrm{s}}^{\prime}$ & $\nu_{\mathrm{a}}$ \\
\hline
\end{tabular}

Table 2.13 shows, in addition to the double bending and symmetric vibration frequencies, a single antisymmetric frequency, $\nu_{a}$, at $909 \mathrm{~m} \mu$. Similarly to Conn and $\mathrm{Wu}$, Satyanarayana considered the occurrence of Raman frequencies other than $\nu_{s}$ evidence of non-linear structure; he calculated (by means of the Penn-Sutherland theory) a value of $140^{\circ}$ for the $\mathrm{O}-\mathrm{O}$ angle. As a tentative explanation of the doubling of the fre-

quencies $\nu_{\mathrm{b}}$ and $\nu_{\mathrm{s}}$, he suggested partial ionization, with some photons scattered by uranyl ions and some by undissociated uranyl chloride molecules. Satyanarayana also found that the $865 \mathrm{~cm}^{-1}$ Raman line was strongly polarized. 
67

Cranda11 (1947,1949) measured the Raman lines of uranyl chloride solutions of different concentrations, and compiled Table 2.14, which includes the earlier results of Conn and $\mathrm{Wu}$, and of Satyanarayana.

Table 2.14

RAMAN FREQUENCIES IN URANYL SALT SOLUTION (AFTER CRANDALL)

\begin{tabular}{|c|c|c|c|c|c|c|}
\hline \multirow{3}{*}{ Frequency } & \multirow{3}{*}{$\begin{array}{c}\text { Perchlorate (sat.) } \\
\text { (Crandail) }\end{array}$} & \multicolumn{3}{|c|}{ Chloride } & \multirow{3}{*}{$\begin{array}{c}\text { Nitrate } \\
\text { (sat.) } \\
\text { (Conn, } \\
\text { Wu) }\end{array}$} & \multirow{3}{*}{$\begin{array}{c}\text { Sulfate } \\
\text { (sat.) } \\
\text { (Conn, } \\
\text { Wu) }\end{array}$} \\
\hline & & \multicolumn{2}{|c|}{ Sa turated } & \multirow{2}{*}{$\begin{array}{l}\text { 1. } 2 \mathrm{M} \mathrm{UO}_{2} \mathrm{Cl}_{2} \\
\text { 1. } \mathrm{OM}^{+} \mathrm{HCl} \\
\text { 1. } 2 \mathrm{M}^{+} \mathrm{NH}_{4} \mathrm{Cl} \\
\text { (Crandall) }\end{array}$} & & \\
\hline & & (Conn, Wu) & (Satyanarayana) & & & \\
\hline$\nu_{\mathrm{s}}$ (symmetric) & 880 & 860 & $865,853^{*}$ & 864 & 863 & 860 \\
\hline$\nu_{\mathrm{a}}$ (asymmetric) & - & - & $90 g^{*}$ & - & - & - \\
\hline$\nu_{b}$ (bending) & $199^{\frac{*}{k}}$ & 210 & 226,197 & 204 & 210 & 210 \\
\hline
\end{tabular}

*Weak lines

Crandall considered the difference between the frequencies in uranyl perchlorate solution and in the solutions containing other anions as an indication of complexing (of which incomplete dissociation, suggested by Satyanarayana, is a special case). The doublet structure found in Satyanarayana's experiments can then be interpreted as indicating the presence of two types of complexes. Crandall suggested that complexing may be responsible for an angular structure (if the occurrence of prohibited Raman lines is to be considered as proof that the $\mathrm{UO}_{2}^{++}$ion, which is linear in crystals, becomes angular in solution) or, alternatively, for the violation of exclusion rules theoretically valid for linear structures (if the $\mathrm{UO}_{2}^{++}$ion is assumed to remain linear in solution).

Crandall's experiments were made in connection with $\mathrm{O}^{18}$ exchange studies between uranyl ions and water. These studies indicated that the noncomplexed ion has simple structure

$$
\left[\mathrm{O}={ }^{+} \mathrm{U}^{+}=\mathrm{O}\right]^{+2}
$$

with four covalent bonds, and made unlikely the structure<smiles>O=CC(O)CO</smiles>

with four ionic bonds between a central $\mathrm{U}^{+6}$ ion and four $\mathrm{OH}^{-}$anions. (If the second model were correct, a fast isotopic exchange of uranyl oxygen with water could be expected.) 
The question of the shape of the $\mathrm{UO}_{2}^{++}$ion in solution was again taken up by Sutton (1952). He compared the Raman spectra of the following solutions: (a) $\mathrm{UO}_{2} \mathrm{Cl}_{2}$, saturated, in water, (b) same, saturated with hydrochloric acid, (c) same, saturated with calcium chloride, (d) same, saturated with $\mathrm{UO}_{3}$; and $(\mathrm{e}) \mathrm{UO}_{2}\left(\mathrm{NO}_{3}\right)_{2}$, saturated. Figures $2.22 \mathrm{~A}-\mathrm{E}$ were obtained with the mercury line $546.1 \mathrm{~m} \mu$ in $2-8 \mathrm{hr}$ exposure.

The "prohibited" $\nu_{a}$ frequency (about $980 \mathrm{~cm}^{-1}$ ) is not recognizable in (A), but appears clearly in (B) and (C), where $\mathrm{Cl}^{-}$ions were present in large excess. Sutton considers this evidence of formation of complexes of $\mathrm{UO}_{2}^{++}$with $\mathrm{Cl}^{-}$, in which the entrance of $\mathrm{Cl}^{-}$ions into the hydration spheres of the cations: $\mathrm{UO}_{2}^{++} \cdot 6 \mathrm{H}_{2} \mathrm{O}+\mathrm{Cl}^{-} \longrightarrow \mathrm{UO}_{2}^{++} \mathrm{Cl}^{-} \cdot 5 \mathrm{H}_{2} \mathrm{O}$, creates an asymmetric electric field that makes the prohibited transition possible. (Using the $\mathrm{UO}_{2} \mathrm{~F}_{2}$ crystal structure as a model, Sutton postulated that water molecules form a puckered $\mathrm{ring}$ around the $\mathrm{O}-\mathrm{U}-\mathrm{O}$ axis, with an $\mathrm{O}-\mathrm{U}$ about $73^{\circ}$.)

The even more pronounced appearance of the $\nu_{a}$ frequency in uranyl chloride solution saturated with $\mathrm{UO}_{3}$ (Figure $2.22 \mathrm{D}$ ) can be attributed to the formation of complex polyuranyl ions

$$
\mathrm{UO}_{2}^{++}+\mathrm{UO}_{3} \longrightarrow\left\{\mathrm{UO}_{2}^{++}-\mathrm{O}^{--}-\mathrm{UO}_{2}^{++}\right\}^{++}\left(=\mathrm{U}_{2} \mathrm{O}_{5}^{++}\right)
$$

(cf. Section 3), in which the $\mathrm{O}^{--}$ion in the "bridge" exercises a similar (but stronger) asymmetric electric influence on the linear $\mathrm{UO}_{2}^{++}$ions as does the $\mathrm{Cl}^{-}$ion in the chloride complexes.

The occurrence in nitrate solution (Figure $2.22 \mathrm{E}$ ) of the $\nu_{\mathrm{a}}$ frequency, with an intensity intermediate between those in Figures $2.22 \mathrm{~B}, \mathrm{C}$ on the one hand, and Figure 2.22 D on the other, is taken by Sutton as confirmation of the conclusion of Betts and Michels (1949) that the uranyl ion has a stronger tendency to complex with $\mathrm{NO}_{3}^{-}$ions than with $\mathrm{Cl}^{-}$ion (for contradictory evidence, see Section 2.1). In this case (Sutton suggests) two adjacent water molecules in the hydration sphere can be replaced by two nitrate oxygens $\left(\mathrm{UO}_{2}^{++} \cdot 6 \mathrm{H}_{2} \mathrm{O}+\mathrm{NO}_{3}^{-} \longrightarrow \mathrm{UO}_{2}^{++} \mathrm{NO}_{3}^{-} \cdot 4 \mathrm{H}_{2} \mathrm{O}\right)$.

The $\nu_{\mathrm{b}}$ frequency is not separated from the mercury line in Figures $2.22 \mathrm{~A}-\mathrm{E}$ because of insufficient dispersion; however, its presence is revealed by the distortion of the shape of this line, which is least pronounced in curve (A) and stronger in curves (B-E).

Sutton suggested that if the above argument is correct, the prohibited lines can be expected to be weaker in complex ions of higher symmetry, such as the trinitratouranyl ion, which is formed, according to Kaplan et al. $(1950 \mathrm{a}, \mathrm{b})$, in uranyl nitrate solutions in organic solvents in the presence of quaternary ammonium nitrates., 


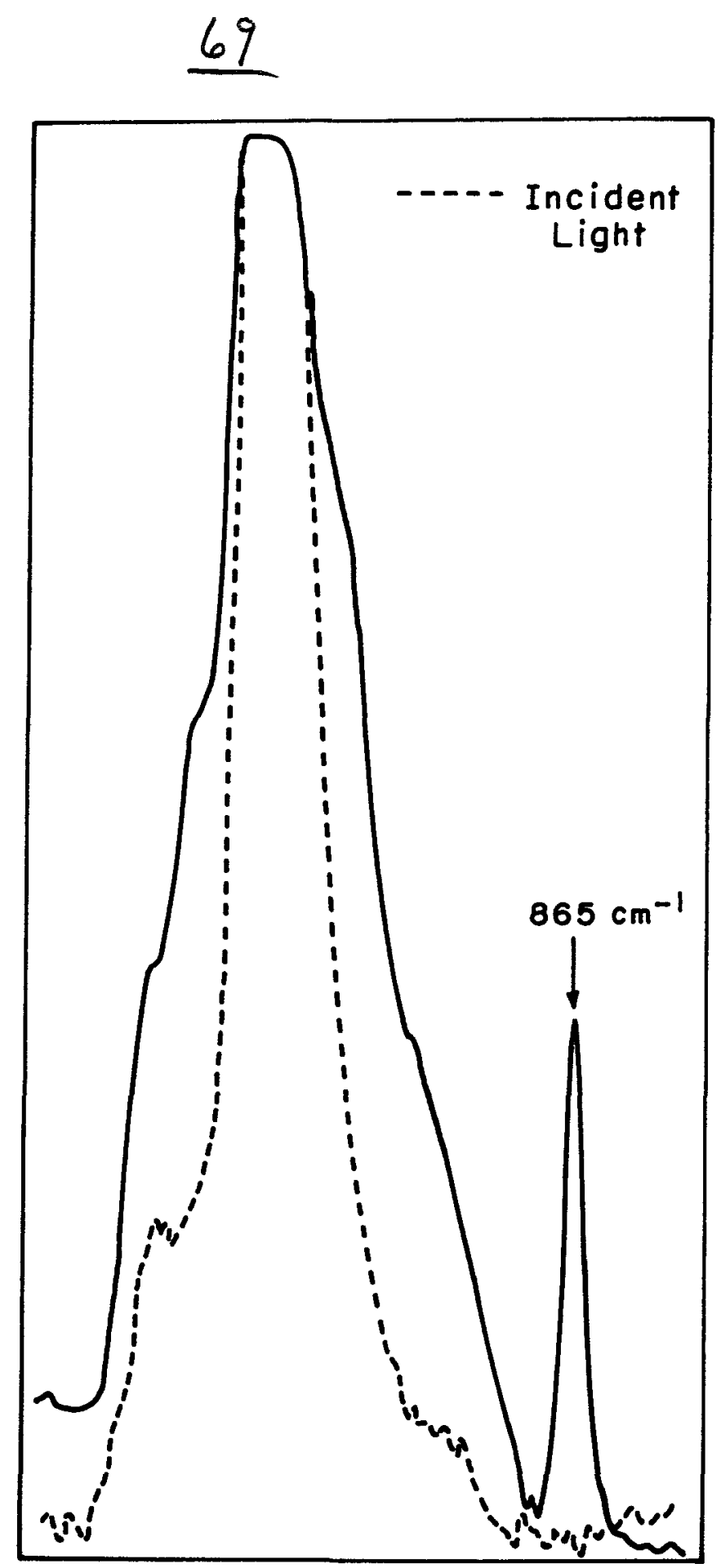

FIG. 2.22A-RAMAN SPECTRUM OF $\mathrm{UO}_{2} \mathrm{Cl}_{2}$. 
70

70

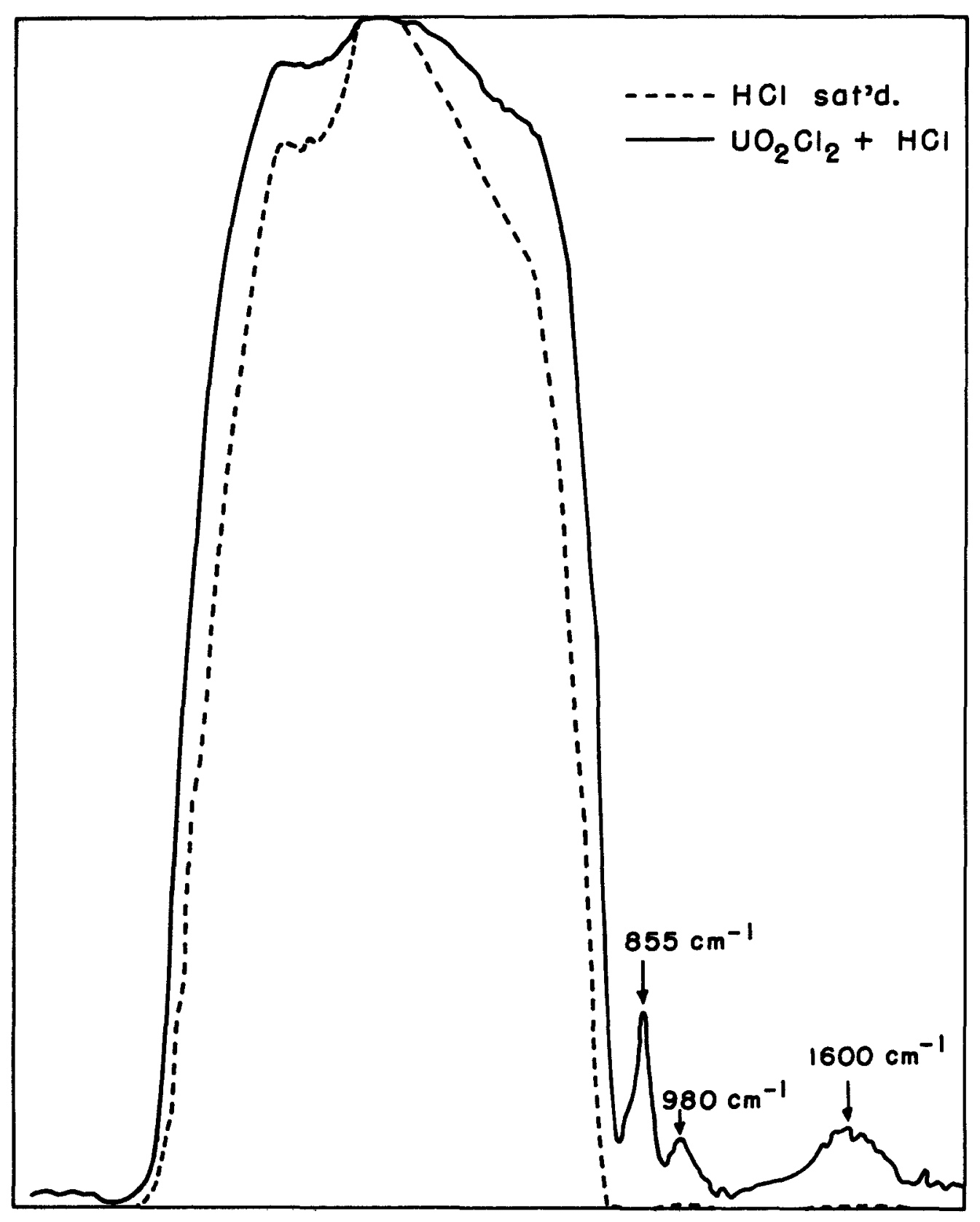

FIG. 2.22B-RAMAN SPECTRUM OF $\mathrm{UO}_{2} \mathrm{Cl}_{2}$ SATURATED 'WITH $\mathrm{HCl}$. 


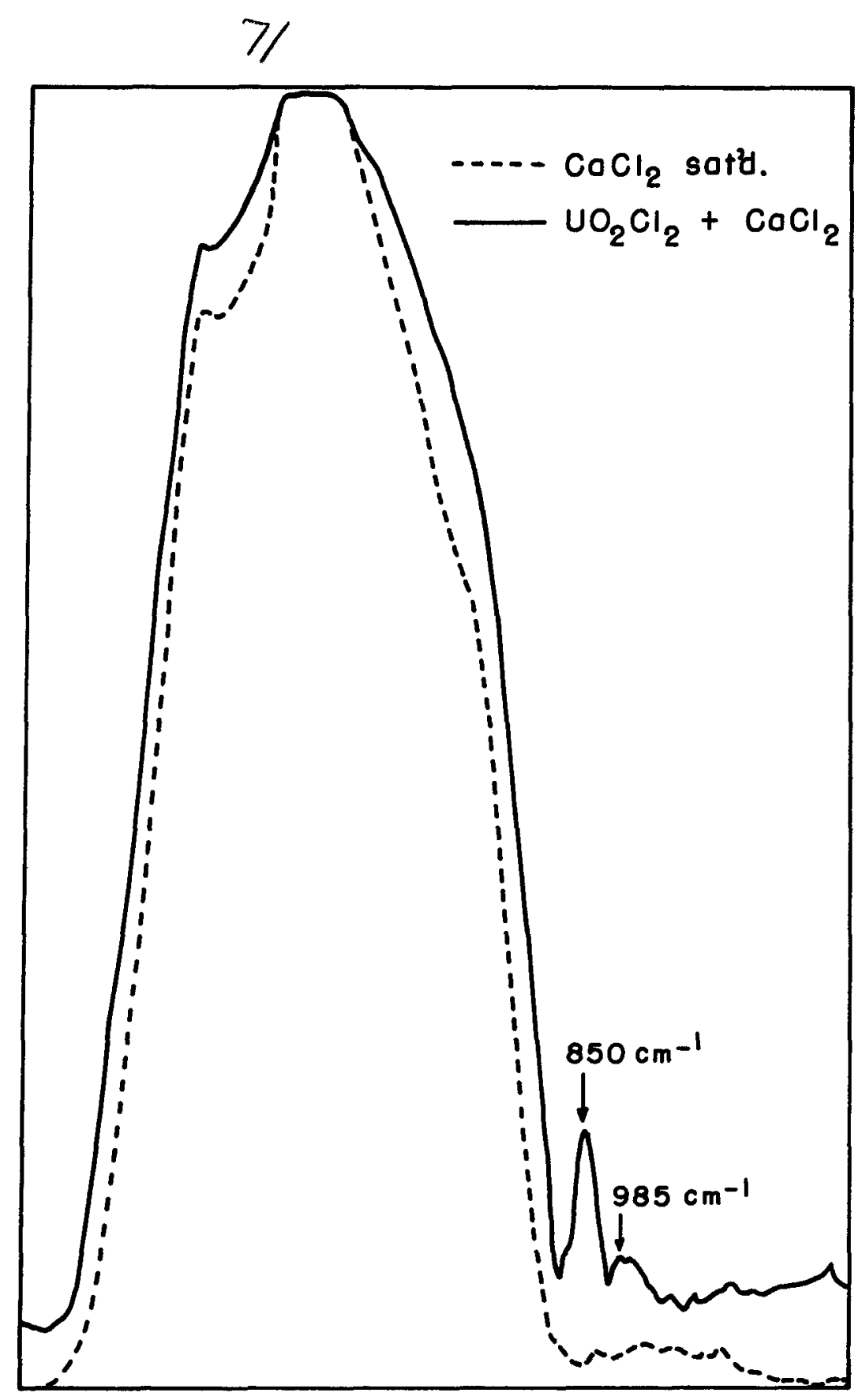

FIG.2.22C-RAMAN SPECTRUM OF $\mathrm{UO}_{2} \mathrm{Cl}_{2}$ SATURATED WITH $\mathrm{COCl}_{2}$. 


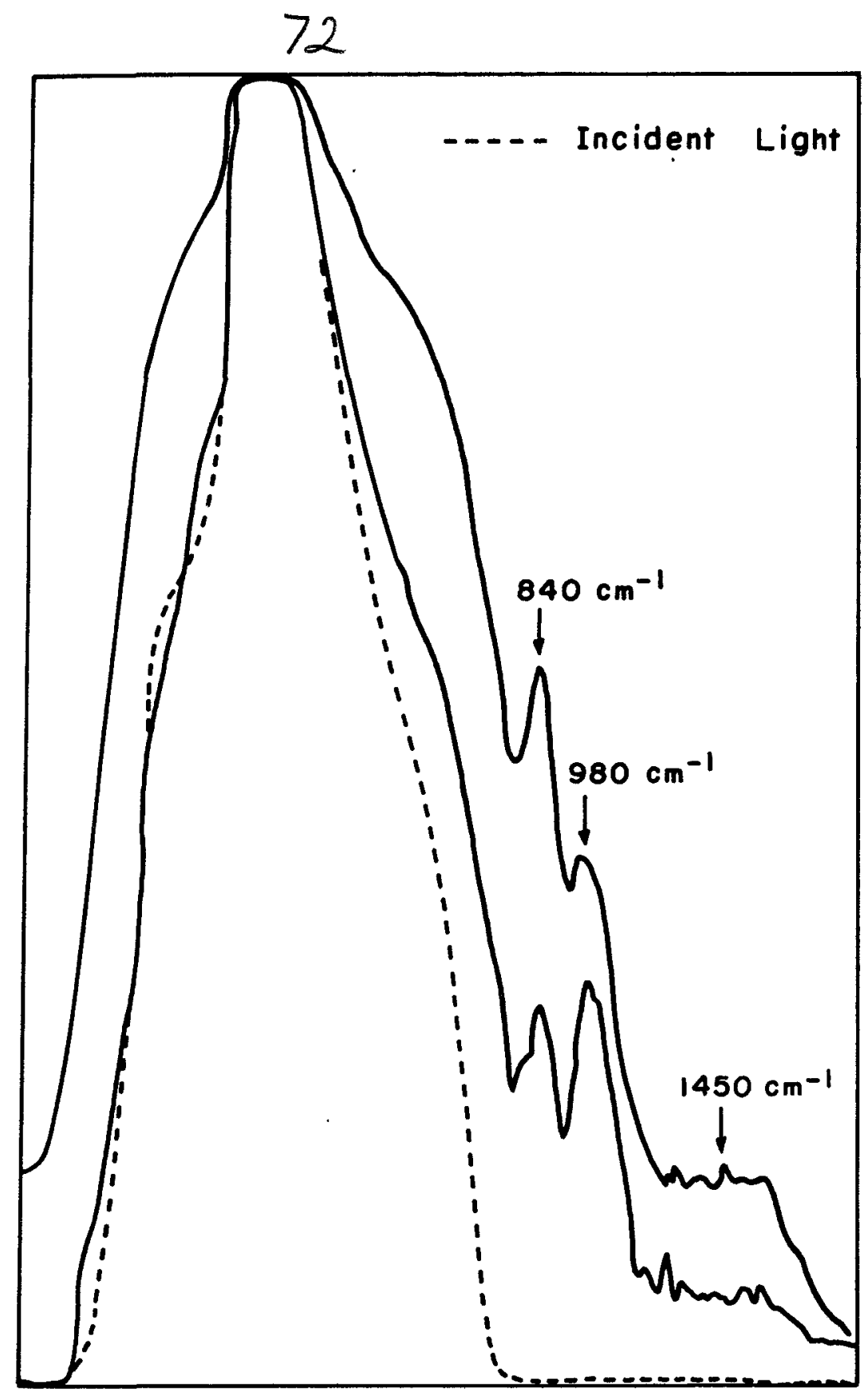

FIG 2.220-RAMAN SPECTRUM OF $\mathrm{UO}_{2} \mathrm{Cl}_{2}$ SATURATED WITH $\mathrm{UO}_{3}$. 
73

73

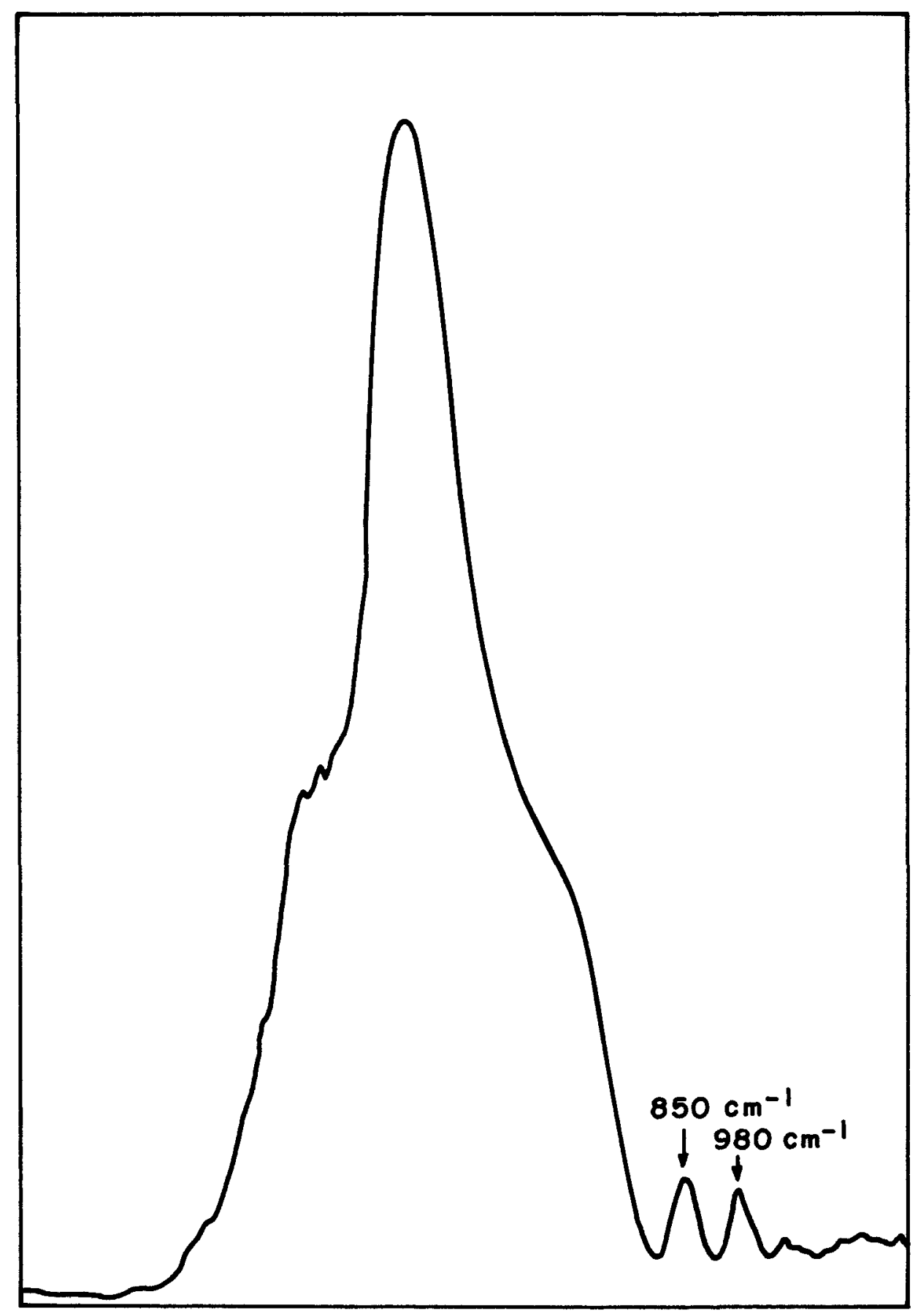

FIG. 2.22E-RAMAN SPECTRUM OF URANYL NITRATE. 


\section{4}

Infrared Absorption Spectrum - Data on the infrared absorption spectrum of uranyl intake solutions are included in Table 1.4 (ANL-5122) by Sevchenko and Stepanov (1949). 
75

REFERENCES

1873 H. Morton and H.C.Bolton, Chem. News, 28: 47-50, 113-116, $164-167,233-234,244-246,257-259,268-270$.

1890 H. Bremer, Dissertation, Erlangen.

1891 O. Knoblauch, Wied.Ann., 43: 738.

$1892 \mathrm{H}$. Bremer, Z, anorg. Chem, l: 112-125.

1898 E. Deussen, Wied. Ann。, 66: 428.

1903 W. N. Hartley, J.Chem.Soc。(London), 83: 221-246.

1905 H. Kayser, "Handbuch der Spectroskopie," Bd. 3, S. Hirzel, Leipzig。

$1910 \mathrm{a}$ H. C. Jones and W.W. Strong, Carnegie Inst.Wash. Pub., 130.

$1910 \mathrm{~b} H . C$. Jones and W. W. Strong, Am.Chem.J., 43: 37-90, 97-135.

$1911 \mathrm{a} \mathrm{H}$. C. Jones and W.W.Strong, Am.Chem. J., 45: 1-36, 113-159.

$1911 \mathrm{~b} \mathrm{H}$. C. Jones and W. W. Strong, Carnegie Inst. Wash. Pub., 160.

1912 H. C. Jones and W. W. Strong, Am。Chem. J。, 47: 27-85, 126-179.

$1913 \mathrm{a}$ H。C.Jones, J。Franklin Inst., 176: 479-564, 677-704.

$.1913 \mathrm{~b}$ H.C.Jones and J。S.Guy, Am. Chem. J., 49: 1-46.

1914 V. Henri and M. Landau, Compt.rend., 158: 181-183.

1927 V. R. von Kurelec, Biochem。Z., 180: 65-84.

1927 S. Hakomori, Sci.Repts.Tôhoku Imp. Univ., I, 16: 841.

1928 J. C. Ghosh and B. N. Mitter, Quart. J. Indian Chem.Soc., 4: 353-366.

1929 P. Pringsheim and M. Yost, Z. Physik, 58: 1-6.

1929 W. C. Pierce, J. Am.Chem. Soc., 51: 2731-2738.

1936 J.C. Ghosh, T.Banerjee and B. Bhatta, Z. physik. Chem., B32: $163-167$.

1937 P. Pringsheim, Physica, 4: 733-745。

1938 G. K. T. Conn and C。K.Wu, Trans.Faraday Soc., 34: 1483-1492.

1940 A. Mưller, Ber。, 73 B, $1353-1358$.

1942 a A. von Kiss, P. Csokan and G. Nyiri, Z.phys.Chem., Al90: 65-80.

1942b 'A. von Kiss and $G_{\text {。 }}$ Nyiri, Z, anorg。Chem., 249: 340-356.

1942 D. A. MacInnes and L.G. Longsworth, Report MDDC-911.

1942 T. L. Rama Char, J。Indian Chem.Soc., 19: 369.

1942 B. S. Satyanarayana, Proc。Indian Acad. Sci., 15A: 414-416. 


\section{6}

1946 J. J. McBrady and R. Livingston, J. Phys. Chem., 50: 176-190.

1947 H. W. Crandall, Report MDDC-1294.

1947 J. Sutton, Report CRC-325; unpublished work.

1948 W.F. Neuman and R. Havill, Jr., Report AECD-1801.

1948 J.Rodgers and W. F. Neuman, Report AECD-2216.

1949a S. Ahrland, Acta Chem. Scand., 3: 374-400.

1949b S. Ahrland, Acta Chem. Scand., 3: 783-808.

1949c S. Ahrland, Acta Chem. Scand., 3: 1067-1076.

1949 T.V.Arden, J.Chem. Soc. (London), 1949: S299.

1949 R. H. Betts and R. K. Michels, J. Chem. Soc. (London), 1949: S286-294.

1949 A. L. Dounce, J. F. Flagg, P. Fanta, G. H. Tishkoff and Tien Ho Lan, Chapter 1 of "Pharmacology and Toxicology of Uranium Compounds," National Nuclear Energy Series, Division VI, Volume 1, McGraw-Hill Book Co., Inc., New York.

1949 I. Feldman, W. F. Neuman and J. R. Havill, Report UR-85.

1949 R. T. Foley and R. C. Anderson, J. Am. Chem. Soc., 71: 909-912.

1949 M. Kasha, J. Chem. Phys., 17: 349.

1949 A. R. Mathieson, J. Chem. Soc.(London), 1949: S294-298.

1949 W. F. Neuman, J.Havill and I. Feldman, Report AECD-2728.

1949 A. N. Sevchenko and B. I. Stepanov, Thur. Eksptl. Teor et. Fiz., 19: 1113 .

1949 J.Sutton, J. Chem. Soc.(London), 1949: S275-286.

1950 a L. Kaplan, R. A. Hildebrandt and M. Ader, Report ANL-4520.

$1950 \mathrm{~b}$ L. Kaplan, R. A. Hildebrandt and M. Ader, Report ANL-4521.

1951a S. Ahrland, Acta Chem. Scand., 5: 199-219.

$1951 \mathrm{~b}$ S. Ahrland, Acta Chem. Scand., 5: 1151-1167.

1951c S. Ahrland, Acta Chem. Scand., 5: 1271-1282.

1951 R. A. Robinson and C. K. Lim, J. Chem. Soc. (London), 1951: $1841-1843$.

1952 J. Sutton, Nature, 169: 235-237. 